\title{
Leren onder werkenden met een kwetsbare positie op de arbeidsmarkt
}

Citation for published version (APA):

Künn, A., Poulissen, D., van Eldert, P., Fouarge, D., \& de Grip, A. (2018). Leren onder werkenden met een kwetsbare positie op de arbeidsmarkt. ROA. ROA Reports No. 005 https://doi.org/10.26481/umarep.2018005

Document status and date:

Published: 01/01/2018

DOI:

10.26481/umarep.2018005

Document Version:

Publisher's PDF, also known as Version of record

\section{Please check the document version of this publication:}

- A submitted manuscript is the version of the article upon submission and before peer-review. There can be important differences between the submitted version and the official published version of record.

People interested in the research are advised to contact the author for the final version of the publication, or visit the DOI to the publisher's website.

- The final author version and the galley proof are versions of the publication after peer review.

- The final published version features the final layout of the paper including the volume, issue and page numbers.

Link to publication

\footnotetext{
General rights rights.

- You may freely distribute the URL identifying the publication in the public portal. please follow below link for the End User Agreement:

www.umlib.nl/taverne-license

Take down policy

If you believe that this document breaches copyright please contact us at:

repository@maastrichtuniversity.nl

providing details and we will investigate your claim.
}

Copyright and moral rights for the publications made accessible in the public portal are retained by the authors and/or other copyright owners and it is a condition of accessing publications that users recognise and abide by the legal requirements associated with these

- Users may download and print one copy of any publication from the public portal for the purpose of private study or research.

- You may not further distribute the material or use it for any profit-making activity or commercial gain

If the publication is distributed under the terms of Article $25 \mathrm{fa}$ of the Dutch Copyright Act, indicated by the "Taverne" license above, 
Maastricht University

Leren onder werkenden met een kwetsbare positie op de arbeidsmarkt

\section{ROA Rapport}

ROA-R-2018/5

Researchcentrum voor Onderwijs en Arbeidsmarkt | ROA Research Centre for Education and the Labour Market / ROA 


\section{LEREN ONDER WERKENDEN MET EEN KWETSBARE POSITIE OP DE ARBEIDSMARKT}

ROA-R-2018/5

Annemarie Künn-Nelen

Davey Poulissen

Peter van Eldert

Didier Fouarge

Andries de Grip 


\section{Colofon}

(C) Researchcentrum voor Onderwijs en Arbeidsmarkt (ROA). Niets uit deze uitgave mag op enige manier worden verveelvoudigd zonder voorafgaande schriftelijke toestemming van de directeur van het ROA.

\section{Researchcentrum voor Onderwijs en Arbeidsmarkt}

Postbus 616

6200 MD Maastricht

$\mathrm{T}+31433883647$

$\mathrm{F}+31433884914$

secretary-roa-sbe@maastrichtuniversity.nl

www.roa.nl

School of Business and Economics

Maastricht University

\section{Vormgeving}

ROA secretariaat, Maastricht

ISBN: 978-90-5321-568-5

juli 2018

\section{NROO)}

Dit rapport maakt onderdeel uit van het NRO project 'Levenslang leren en competentieontwikkeling' (dossiernummer 405-16-402). 


\section{INHOUD}

Voorwoord

Resumé

vii

1 inleiding

2 Werkgerelateerd leergedrag van werkenden met een kwetsbare positie

2.1 Formeel en informeel leren op het werk 9

2.2 Wie bepaalt en wie betaalt voor cursussen? $\quad 12$

$\begin{array}{ll}2.3 & \text { Redenen voor het volgen van een cursus } \\ & 16\end{array}$

2.4 Het verschil in leren verklaard 18

3 Determinanten van het leren onder werkenden met een kwetsbare positie op de arbeidsmarkt

$\begin{array}{ll}3.155 \text { tot } 66 \text { jarige werkenden } & 27\end{array}$

$\begin{array}{ll}3.2 & \text { Laagopgeleiden } \\ 3.32\end{array}$

3.3 Zelfstandigen 36

3.4 Werknemers met een tijdelijk contract zonder uitzicht op vast 39

4 Bereidheid van werkenden met een kwetsbare positie om cursussen te volgen

4.1 Stimulerende en belemmerende factoren voor cursusdeelname 43

4.2 Verschillen naar kwetsbare positie op de arbeidsmarkt 47

4.3 Stimulerende en belemmerende factoren voor zelfstandigen 52

4.4 Is de bereidheid tot eigen bijdrage afhankelijk van iemands leefsituatie of leefstijl?

4.5 Is de bereidheid tot eigen bijdrage afhankelijk van iemands persoonlijkheid? 
5 Investeringsbereidheid van werkgevers

5.1 Bereidheid om in 60-jarigen te investeren 57

5.2 Bereidheid om in laagopgeleiden te investeren 67

5.3 Bereidheid om te investeren in werkenden met een tijdelijk contract 74

$\begin{array}{ll}\text { Literatuur } & 83\end{array}$

$\begin{array}{lr}\text { Bijlage A } & 87\end{array}$

$\begin{array}{lr}\text { Bijlage B } & 91\end{array}$ 


\section{VOORWOORD}

De Nederlandse overheid ervaart het als zeer urgent een goed levenslang leren beleid te ontwikkelen dat onze kenniseconomie een impuls geeft. Daarbij staan twee aan elkaar gerelateerde vragen centraal:

- Over welke competenties moet de (vergrijzende) Nederlandse beroepsbevolking beschikken?

- Hoe kan de scholing en het informeel leren dat daarvoor nodig is worden gestimuleerd?

Het NRO project Levenslang Leren en competentieontwikkeling (405-16-402) richt zich op het beantwoorden van deze twee vragen.'

Het doel van levenslang leren is het op peil houden en vergroten van het competentieniveau van de Nederlandse bevolking zodat iedereen duurzaam inzetbaar blijft op de arbeidsmarkt. Verschillende groepen werkenden hebben echter een zwakkere positie op de arbeidsmarkt. Dat maakt hun duurzame inzetbaarheid kwetsbaar. Daarom is het erg belangrijk dat deze mensen hun competenties up-to-date houden door te blijven leren.

In dit rapport staat het werkgerelateerde leren van werkenden (het volgen van cursussen en het informeel leren van taken op het werk) met een kwetsbare positie op de arbeidsmarkt centraal. We richten ons hierbij op drie groepen: 55 plussers, laagopgeleiden en werknemers met een tijdelijk arbeidscontract. Waar mogelijk gaan wij ook in op de groep zelfstandigen. ${ }^{2}$ De focus op de hierboven groepen is ingegeven door een drietal maatschappelijke ontwikkelingen, te weten de vergrijzing van de Nederlandse beroepsbevolking, de toenemende opleidingseisen die aan werknemers gesteld worden en de rappe flexibilisering van de Nederlandse arbeidsmarkt. ${ }^{3}$ In het voorliggende rapport zal nog niet worden ingegaan op de beleidsimplicaties van het onderzoek. Hierop zal

1 Zie de ROA website voor meer informatie: http://roa.sbe.maastrichtuniversity.nl/?portfolio=roa-lifelonglearning-survey.

2 Hoewel de groep zelfstandigen erg divers van samenstelling is en met name veel zelfstandigen zonder personeel een kwetsbare positie op de arbeidsmarkt hebben, was het op basis van de beschikbare data niet mogelijk om een onderscheid te maken tussen verschillende groepen zelfstandigen.

3 In Hoofdstuk 1 gaan wij nader in op deze maatschappelijke ontwikkelingen en de keuze voor de in dit rapport bestudeerde groepen met een kwetsbare arbeidsmarktpositie. 
worden ingegaan in het samenvattende beleidsrapport "Levenslang leren en competentieontwikkeling" dat later dit jaar (najaar 2018) verschijnt.

In dit rapport schetsen wij eerst een beeld van het werkgerelateerde leren door werkenden met een kwetsbare positie op de arbeidsmarkt anno 2017 (Hoofdstuk 2). Het werkgerelateerde leren onder deze groepen wordt hierbij telkens vergeleken met dat van een referentiegroep met een sterkere arbeidsmarktpositie. In hetzelfde hoofdstuk onderzoeken wij ook in welke mate het verschil in het werkgerelateerde leren verklaard kan worden op basis van iemands leefstijl en leefsituatie, persoonlijkheid, de inhoud van het werk en het gevoerde HR-beleid in de organisatie waarin iemand werkt. Hierop volgend geeft Hoofdstuk 3 inzicht in de factoren die van invloed zijn op het werkgerelateerde leren van de werkenden met een kwetsbare positie op de arbeidsmarkt. Vervolgens maken we in Hoofdstuk 4 door middel van vignetexperimenten inzichtelijk hoe de cursusdeelname onder mensen met een kwetsbare positie op de arbeidsmarkt kan worden gestimuleerd. Tot slot wordt in Hoofdstuk 5 bekeken hoe de investeringsbereidheid van werkgevers in mensen met een kwetsbare positie op de arbeidsmarkt gestimuleerd zou kunnen worden. Hierbij maken wij eveneens gebruik van vignetexperimenten.

Het onderzoek is uitgevoerd aan de hand van data uit de ROA Levenslang Leren Enquête 2017 en de Nederlandse Skills Survey 2017. Doordat deze metingen beide gehouden zijn onder respondenten van het LISS panel kunnen beide databronnen op individueel niveau worden gekoppeld en worden aangevuld met andere informatie die verzameld is binnen het LISS panel. Ook is in 2017 de ROA Werkgeversenquête Scholingsbeleid uitgevoerd. Deze laatste enquête is gebruikt in het laatste hoofdstuk van dit rapport, waarin ingegaan wordt op de rol die werkgevers kunnen spelen voor het vergroten van de cursusdeelname onder mensen met een kwetsbare positie op de arbeidsmarkt.

Prof. dr. Andries de Grip

Directeur ROA 


\section{RESUMÉ}

Op de Nederlandse arbeidsmarkt spelen momenteel een aantal belangrijke maatschappelijke ontwikkelingen en trends. Zo vergrijst de beroepsbevolking, is er sprake van een upgrading van de werkgelegenheidsstructuur waardoor er steeds hogere opleidingseisen aan werkenden worden gesteld en flexibiliseert de arbeidsmarkt in hoog tempo. Van bepaalde groepen werkenden is bekend dat zij mede als gevolg van deze ontwikkelingen over een minder sterke arbeidsmarktpositie beschikken en daardoor ook het risico lopen dat ze minder participeren in allerhande leeractiviteiten. In dit rapport richten wij ons op 55-66 jarigen, laagopgeleiden en werknemers met een tijdelijk arbeidscontract. Waar mogelijk bespreken we ook het werkgerelateerde leren onder zelfstandigen. ${ }^{4}$ Een beter inzicht in het levenslang leren onder deze groepen werkenden is van belang voor het ontwikkelen van een goed levenslang leren beleid dat de duurzame inzetbaarheid van deze groepen werkenden verbetert en daarmee de Nederlandse kenniseconomie een impuls kan geven. De belangrijkste bevindingen uit dit rapport kunnen als volgt worden samengevat:

Hoofdstuk 2 - Terwijl werkenden met een kwetsbare positie op de arbeidsmarkt minder participeren in training (formeel leren) geldt dit niet altijd voor de mate waarin zij informeel leren.

- Minder dan de helft van de werkenden met een kwetsbare positie op de arbeidsmarkt (d.w.z. behorend tot de groep 55 tot 66 jarigen, laagopgeleiden of werkenden met een tijdelijk arbeidscontract) heeft in de afgelopen twee jaar een werkgerelateerde cursus gevolgd. De referentiegroepen met een sterkere arbeidsmarktpositie participeren beduidend vaker in een cursus of training.

- Laagopgeleiden nemen minder vaak het initiatief om aan een cursus deel te nemen vergeleken met hoogopgeleiden. Werknemers met een tijdelijk contract zonder uitzicht op een vaste aanstelling nemen juist relatief vaak zelf het initiatief.

- Werknemers met een tijdelijk contract betalen veel vaker zelf de training dan werknemers met een vaste baan.

- Laagopgeleiden en werknemers met een tijdelijk contract volgen hun trainingen vaker in hun vrije tijd dan hoogopgeleide werknemers of werknemers met een vaste baan.

4 De selectie van deze groepen wordt onderbouwd in Hoofdstuk 1. 
- Het verschil in trainingsparticipatie tussen verschillende leeftijdsgroepen verdwijnt na een correctie voor verschillen in opleidingsachtergrond, het aantal uren dat men werkzaam is en het soort dienstverband.

- Het verschil in trainingsparticipatie tussen laag- en hoogopgeleiden kan voor bijna de helft verklaard worden door verschillen in werkinhoud. Het gaat dan voornamelijk om verschillen in het takenpakket.

- De lagere trainingsparticipatie onder werknemers met een tijdelijk dienstverband zonder perspectief op een vaste aanstelling wordt voor een relatief groot deel verklaard door de inhoud van het werk en de context waarin wordt gewerkt. Het betreft hierbij zowel de mate van concurrentie in de markt, de mate van organisatorische ontwikkelingen als het takenpakket.

- Het verschil in informeel leren op het werk tussen laag- en hoogopgeleiden verdwijnt na een correctie voor het verschil in leeftijd, contractvorm, persoonlijkheid en door verschillen in de inhoud van het werk tussen deze groepen.

- Ouderen en laagopgeleiden besteden in vergelijking tot hun referentiegroepen relatief weinig werktijd aan taken waarvan zij kunnen leren (informeel leren), maar werknemers met een tijdelijk dienstverband juist relatief veel.

- Verschillen in informeel leren op het werk tussen werknemers met een vast en tijdelijk dienstverband blijken slechts gedeeltelijk het gevolg van minder ervaring.

Hoofdstuk 3 - Onder alle groepen met een kwetsbare positie op de arbeidsmarkt verklaart het door de werkgever gevoerde HR-beleid onder laagopgeleiden het grootste deel van de variantie in het formele en informele leren.

- Het door de werkgever gevoerde HR-beleid heeft beduidend minder invloed op de trainingsparticipatie van 55-66 jarigen dan op de trainingsdeelname van werkenden uit andere leeftijdsgroepen. Bij oudere werkenden zijn vooral taakroulatie en coaching gerelateerd aan cursusdeelname.

- Technologische ontwikkelingen zijn onder alle leeftijdsgroepen positief gerelateerd aan de mate waarin werkenden informeel leren op het werk.

- Laagopgeleiden met een tijdelijk contract zonder uitzicht op vast hebben een kwart minder kans om een cursus te volgen. Onder laagopgeleide vrouwen is de kans op cursus 14 procent lager dan onder laagopgeleide mannen.

- De inhoud van het werk is medebepalend voor de cursusparticipatie van laagopgeleiden.

- Het HR-beleid is erg bepalend voor de trainingsdeelname van laagopgeleiden. Met name de feedback van collega's en het hebben van een opleidings- of ontwikkelplan spelen een positieve rol.

- Laagopgeleide vrouwen leren ruim 6,5 procent minder van de taken op hun werk dan laagopgeleide mannen. Dit is voornamelijk toe te schrijven aan het feit dat laagopgeleide vrouwen vaker in bedrijven werken waar sprake is van weinig technologische veranderingen. 
- Het informeel leren op het werk van laagopgeleiden wordt vooral bepaald door de inhoud van het werk (voornamelijk als gevolg van technologische veranderingen) en het HR-beleid.

- Het hebben van een persoonlijk opleidings- of ontwikkelplan is niet alleen gerelateerd aan de cursusparticipatie van laagopgeleiden, maar ook aan de mate waarin zij informeel leren op hun werk.

- Cursusparticipatie onder zelfstandigen is positief gerelateerd aan zowel opleidingsniveau als leeftijd.

- Onder zelfstandigen blijken persoonlijkheidskenmerken voor een relatief groot deel bepalend voor de mate van informeel leren op het werk.

- De inhoud van het werk is voor werknemers met een tijdelijk contract zonder uitzicht op vast minder sterk gerelateerd aan de cursusparticipatie dan bij vaste medewerkers en bij tijdelijke medewerkers met uitzicht op een vast contract.

- Net als bij zelfstandigen, wordt de mate van informeel leren op het werk ook bij werknemers met een tijdelijke aanstelling zonder uitzicht op een vaste aanstelling, voor een belangrijk deel bepaald door persoonlijkheidskenmerken.

Hoofdstuk 4 - De cursusdeelname van werkenden kan onder andere gestimuleerd worden door géén of slechts een beperkte eigen bijdrage in termen van tijd en geld te vragen.

- Werknemers met een tijdelijk dienstverband zonder uitzicht op een vast contract laten zich in hun cursuskeuze niet negatief beïnvloeden door een eigen bijdrage in termen van geld of tijd. Dit geldt wel voor laagopgeleide en 55-66 jarige werknemers.

- Er zijn weinig verschillen in de stimulerende en belemmerende factoren voor de cursuskeuze tussen werknemers met een zwakke positie op de arbeidsmarkt en werknemers met een goede positie.

- Bij werknemers met een tijdelijk contract zonder uitzicht op een vast contract is er géén relatie tussen het aantal binnen een scholingsexperiment gekozen cursussen die zij daadwerkelijk zouden willen volgen en hun in de praktijk waargenomen trainingsparticipatie. Dit suggereert dat de in de praktijk lagere trainingsparticipatie onder deze groep werkenden het gevolg is van een geringere bereidheid tot het aanbieden van cursussen door de werkgever.

- Persoonskenmerken, persoonlijkheid, leefstijl en leefsituatie, inhoud van het werk en HR-beleid zijn veel beter in staat om de trainingsbereidheid van werknemers met een tijdelijk dienstverband zonder uitzicht op een vast contract te verklaren dan hun daadwerkelijke trainingsparticipatie. 
Hoofdstuk 5 - Van alle onderzochte groepen met een kwetsbare positie op de arbeidsmarkt zijn werkgevers het minst bereid om in de scholing van tijdelijke werknemers te investeren. Ook blijken werkgevers minder bereid om in 60-jarigen te investeren, maar maken ze geen onderscheid tussen laag-en hoogopgeleiden.

- Werkgevers zijn minder bereid om in de scholing van 60-jarigen te investeren dan in die van 30 en 45-jarigen. Er is echter geen verschil in bereidheid om in de scholing van 45 -jarigen of 30 -jarigen te investeren.

- In deeltijd werken verkleint de kans om scholing aangeboden te krijgen aanzienlijk. Dit negatieve effect op de scholingskans geldt voor werkenden uit alle leeftijdscategorieën.

- Werknemers met een goede motivatie en performance maken significant meer kans om scholing aangeboden te krijgen. Het positieve effect van een goede motivatie is groter dan het positieve effect van een goede performance.

- 60-jarigen met een goede motivatie en performance kunnen hun lagere kans op scholing als gevolg van hun leeftijd (deels) compenseren doordat een goede motivatie en goede performance de kans op scholing juist verhogen De motivatie van een 60-jarige speelt daarbij een belangrijkere rol dan zijn of haar performance. Een 60-jarige met een goede performance en een goede motivatie heeft een vergelijkbare kans op scholing als een 30 - of 45 -jarige die op beide kenmerken voldoende scoort.

- Werkgevers schatten de gemiddelde leermotivatie en het gemiddelde leervermogen van oudere werknemers lager in. Dit beeld van oudere werknemers vormt een gedeeltelijke verklaring voor hun lagere bereidheid om in de scholing van 6o-jarigen te investeren.

- Werknemers die bereid zijn een eigen bijdrage te leveren in termen van tijd of geld hebben een grotere kans om scholing te ontvangen. Het positieve effect van een eigen bijdrage vlakt snel af naarmate de eigen bijdrage hoger is, terwijl dat niet geldt voor een eigen bijdrage in termen van tijd.

- Werkgevers bieden het liefst scholing aan gericht op vaktechnische kennis en vaardigheden. Het trainen van sociale en communicatie vaardigheden is onder werkgevers minder populair. Dit geldt nog sterker voor scholing op het gebied van loopbaanoriëntatie en coaching.

- Werkgevers zijn niet minder bereid om in de scholing van laagopgeleiden te investeren dan in de scholing van hoogopgeleiden. Er is wel een lichte voorkeur om in middelbaar opgeleiden te investeren in plaats van in laag- of hoogopgeleiden.

- Werkgevers schatten de leermotivatie en het leervermogen van laagopgeleiden iets lager in dan voor de middelbaar- en hoogopgeleiden. Deze verschillen zijn echter iets minder groot dan de verschillen tussen verschillende leeftijdsgroepen.

- De bereidheid om in laagopgeleiden te investeren blijkt nauwelijks afhankelijk van de werkgeversinschattingen met betrekking tot het leervermogen en de leermotivatie van deze groep.

- Werkgevers zijn fors minder bereid om in de scholing van werknemers met een tijdelijke aanstelling te investeren. Werknemers met een tijdelijk contract zonder uitzicht 
op een vaste aanstelling ondervinden hiervan veruit het grootste nadeel. Zij hebben bijna 40 procentpunt minder kans om scholing te ontvangen dan werknemers die in vaste dienst zijn.

- Tijdelijke werknemers die wél uitzicht hebben op een vaste aanstelling zijn iets beter af, maar maken nog steeds 10 procentpunt minder kans op scholing dan werknemers die in vaste dienst zijn.

- Werkgevers zijn minder bereid om in scholing te investeren die ook buiten de eigen organisatie inzetbaar is. Dit is vooral nadelig voor werkenden met een tijdelijke aanstelling aangezien zij eerder gedwongen zullen zijn op zoek te gaan naar een andere baan.

- Grotere organisaties zijn over het algemeen iets vaker bereid om in breed inzetbare scholing te investeren dan kleinere organisaties. Dit geldt echter alleen voor investeringen in vaste medewerkers of tijdelijke medewerkers met uitzicht op een vaste aanstelling en níet voor tijdelijke werknemers zonder uitzicht op een vaste aanstelling.

- Een terugbetalingsverplichting van de gemaakte scholingskosten bij vroegtijdig vertrek en een eigen financiële bijdrage vanuit de werknemer verhogen de kans op het aanbieden van scholing voor tijdelijke werknemers zonder uitzicht op een vaste aanstelling.

- Tijdelijke werknemers zónder uitzicht op vast werk hebben zelfs bij een hoge eigen bijdrage een veel lagere scholingskans dan tijdelijke werknemers mét uitzicht op vast of vaste medewerkers zonder een dergelijke eigen bijdrage.

- Als werknemers met een tijdelijk contract mét perspectief op vast gebonden zijn aan een terugbetalingsverplichting van 50\% van de scholingskosten bij vroegtijdig vertrek hebben zijn een vergelijkbare scholingskans als vaste medewerkers zónder enige terugbetalingsverplichting.

- Tijdelijke werknemers zónder uitzicht op vast hebben altijd een lagere kans op scholing dan vaste medewerkers. Ook als de tijdelijke werknemer $100 \%$ van de scholingskosten moet terugbetalen bij vroegtijdig vertrek en de vaste werknemer niets hoeven terug te betalen. 



\section{INLEIDING}

Verschillende groepen werkenden hebben geen sterke positie op de arbeidsmarkt. Dat maakt hun duurzame inzetbaarheid kwetsbaar. Voor deze duurzame inzetbaarheid is het erg belangrijk dat deze mensen hun competenties op peil en up-to-date houden door te blijven leren. In dit rapport staat het werkgerelateerde leren van werkenden met een kwetsbare positie op de arbeidsmarkt centraal. Wij gaan in het bijzonder in op vier groepen, die om uiteenlopende redenen, een precaire positie hebben als het gaat om het deelnemen aan of het toegang krijgen tot leeractiviteiten:

- 55-66 jarigen

- laagopgeleiden

- werknemers met een tijdelijk contract

- zelfstandigen ${ }^{5}$

De reden voor de specifieke focus op deze vier groepen is ingegeven door drie belangrijke ontwikkelingen op de arbeidsmarkt: de veroudering van de beroepsbevolking, upgrading van de werkgelegenheidsstructuur en de flexibilisering van de arbeidsmarkt. Een algemeen beeld met betrekking tot de ontwikkeling van formeel en informeel leren in Nederland wordt gegeven in het eerder uitgebrachte rapport "Nederland in leerstand" (Fouarge et al, 2018).

\section{Vergrijzing van de arbeidsmarkt}

De potentiële beroepsbevolking in Nederland veroudert. Aan de ene kant worden er minder kinderen geboren en aan de andere kant leven mensen gemiddeld steeds langer. Figuur 1.1 laat zien dat deze demografische ontwikkeling ook gevolgen heeft voor de arbeidsmarkt. In deze figuur wordt naast de gemiddelde leeftijd ook de Generatie-index van werkenden in de periode 2001-2014 weergegeven. Deze Generatie-index geeft de verhouding weer van het aantal vijftigers onder de groep werkenden ten opzichte van de dertigers. Een index boven de één geeft aan dat het aantal vijftigers in de meerderheid zijn.

5 Hoewel met name zelfstandigen zonder personeel een kwetsbare positie hebben op de arbeidsmarkt, is het in de rest van dit rapport niet mogelijk deze specifieke groep te onderscheiden. 
Figuur 1.1 laat zien dat de gemiddelde leeftijd van werkenden sinds 2001 duidelijk is gestegen. In 2001 was de gemiddelde leeftijd van alle werkenden 38,3 jaar. In 2014 is dit gestegen naar 41,9 jaar. Ook de generatie-index vertoont een duidelijke opwaartse trend. Sinds 2013 werken er meer vijftigers dan dertigers. Het zijn echter niet alleen demografische ontwikkelingen die de stijgende gemiddelde leeftijd en generatie-index verklaren. De netto arbeidsparticipatie van oudere werkenden is namelijk ook sterk gestegen. Voor 55-64-jarigen is er bijvoorbeeld sprake geweest van een stijging van 30 procent in 1996 naar ongeveer 70 procent in 2015. Voor een belangrijk deel is deze stijging te danken aan hervormingen op het terrein van pensioenen (Euwals et al. 2010).

FIGUUR 1.1 Gemiddelde leeftijd en generatie index werkenden, 2001-2014

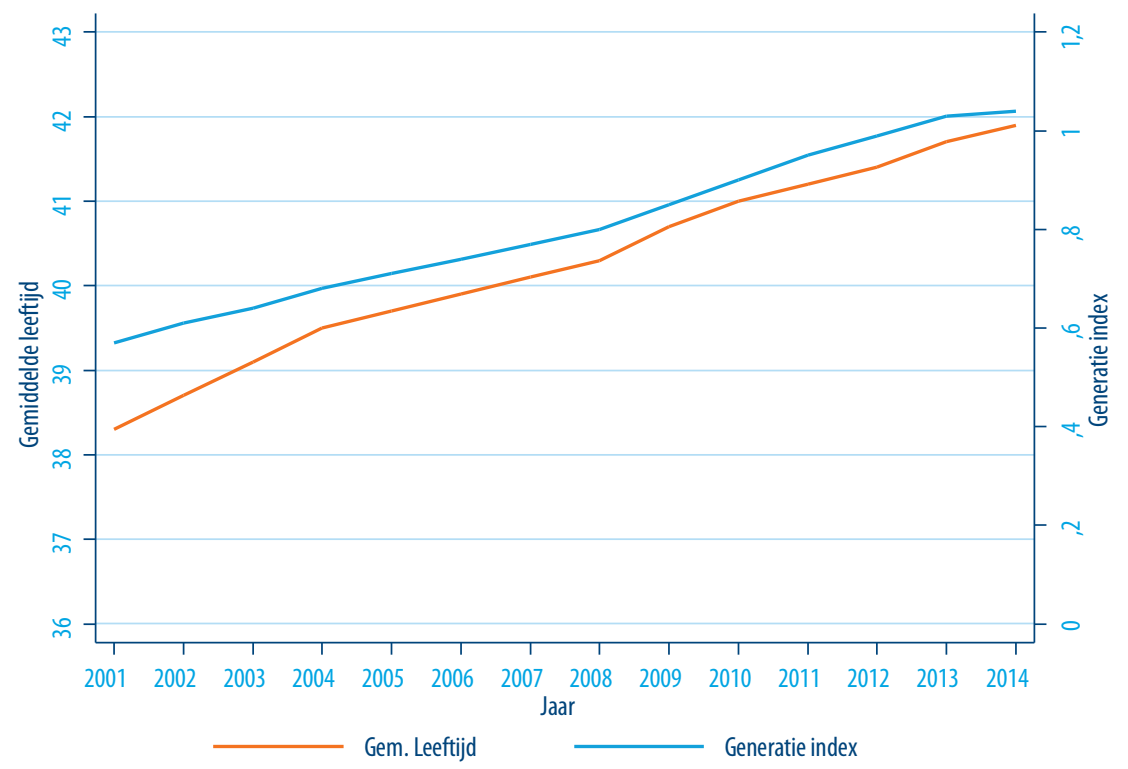

Bron: Statline 'Werkzame beroepsbevolking: vergrijzing SBI 2008; 2001-2014'

Noot: De Generatie index geeft de verhouding weer tussen het aantal vijftigers en het aantal dertigers. Bij een index van 1 zijn beide groepen in evenwicht. Wanneer de index groter is dan 1, dan zijn de vijftigers in de meerderheid.

Een relatief groot aantal 50-plussers in de werkzame bevolking leidt niet alleen tot mogelijke vervangingsproblemen zodra de pensioengerechtigde leeftijd bereikt is, maar brengt nu ook al uitdagingen met zich mee. Zo hebben ouderen die hun baan verliezen veel moeite met het vinden van een nieuwe baan (Bierings en Loog, 2013), waardoor de langdurige werkloosheid onder ouderen toeneemt (Graaf-Zijl et al., 2015). Vaak wordt als reden aangegeven dat oudere werkenden een lagere productiviteit zouden hebben dan de lonen die zij betaald krijgen (Montizaan et al., 2016). Wetenschappelijk bewijs hiervoor is echter niet overtuigend (Van Ours en Stoeldraijer, 2011) en Montizaan et al. (2016) laten 
zien dat werkgevers oudere werknemers weliswaar vooral qua aanpassingsvermogen en flexibiliteit gemiddeld genomen minder goed inschatten dan jongere medewerkers, maar dat oudere werknemers in de ogen van werkgevers op bepaalde terreinen ook over betere competenties beschikken dan jongere medewerkers. Zo zijn werkgevers als het op oudere werknemers aankomt onder andere positief over hun vakkennis, professionaliteit, verantwoordelijkheid en planning van werkzaamheden.

Om oudere werkenden (langer) productief in te kunnen blijven zetten op de arbeidsmarkt wil de overheid het 'leven lang leren' in Nederland versterken. ${ }^{6}$ Bij een effectief leven lang leren beleid blijven de kennis en vaardigheden van werkenden up-to-date en blijven ook oudere werkenden goed inzetbaar. Zoals Figuur 1.2 laat zien is de cursusdeelname van 60-plussers tussen 2004 en 2017 sterk gestegen. De trainingsparticipatie van oudere werkenden blijft echter nog steeds wel achter op die van jongere werkenden. De toename van de trainingsdeelname onder de 6o-plussers is waarschijnlijk voor een deel het gevolg van de pensioenherzieningen, waardoor ouderen gestimuleerd worden langer door te werken en dus ook te investeren in hun eigen kennis en vaardigheden (Montizaan et al., 2010). Het langer doorwerken maakt het ook aantrekkelijker voor werkgevers om te investeren in het menselijk kapitaal van hun oudere arbeidskrachten. Desalniettemin hebben in 2017 oudere werkenden nog steeds een lagere kans om een cursus te volgen dan jongeren. Mogelijke verklaringen hiervoor kunnen liggen bij de werkenden zelf (bijvoorbeeld hun preferenties en motivatie) of bij de werkgever (bijvoorbeeld hun perceptie van de inzetbaarheid van oudere werkenden). Op deze mogelijke verklaringen gaan wij in dit rapport dieper in.

$\overline{6}$ Zie onder andere het Regeerakkoord 2017-2021, oktober 2017. 
FIGUUR 1.2 Formeel leren: ontwikkeling van deelname aan cursussen en trainingen door werkenden naar leeftijd, 2004-2017

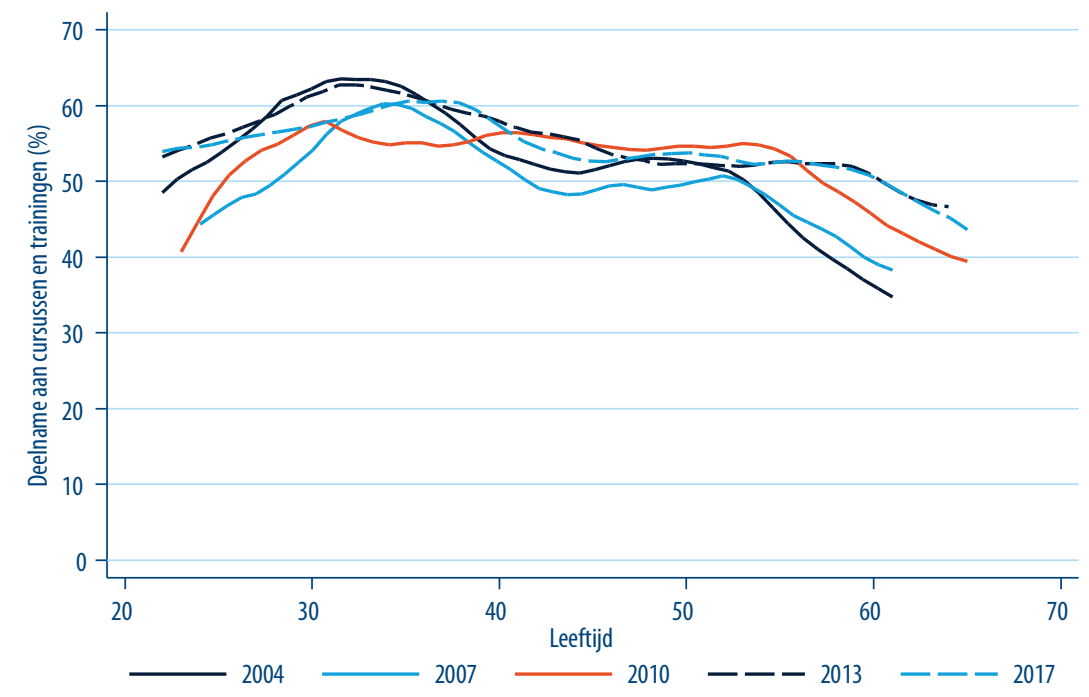

Bron: ROA LLL enquête, 2004-2017

\section{Upgrading van de arbeidsmarkt}

Niet alleen de leeftijdsopbouw van de werkzame beroepsbevolking verandert over de tijd, maar ook de samenstelling van de werkzame bevolking naar opleidingsniveau. Figuur 1.3 laat duidelijk zien het opleidingsniveau van werkend Nederland de afgelopen decennia verder is gestegen. Het aandeel hoger opgeleiden (hbo of wo gediplomeerden) is in de afgelopen 20 jaar vrijwel continu gestegen, terwijl het aandeel laagopgeleiden (vmbo of lager) gestaag afneemt. 
FIGUUR 1.3 Aandeel werkenden naar opleidingsniveau, 1996-2016

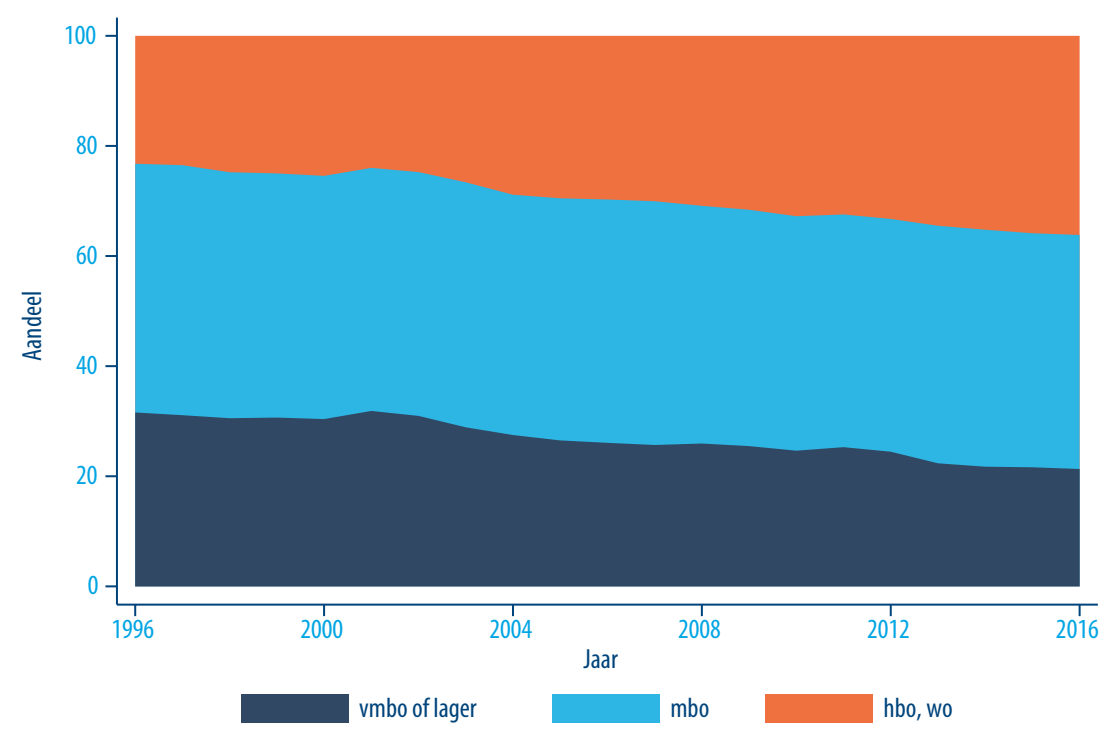

Bron: Fouarge (2017)

Bijlsma et al. (2015) laten zien dat de stijging van het gemiddelde opleidingsniveau tussen 1996 en 2012 bijna 2 opleidingsjaren bedraagt. Uit figuur 1.3 is niet op te maken of de stijging van het opleidingsniveau van werkenden het gevolg is van verschuivingen in de beroepenstructuur of van hogere aanstellingseisen binnen de verschillende beroepsgroepen. Aanvullende analyses door Bijlsma et al. (2015) laten zien dat de toename in het gemiddeld opleidingsniveau vooral het gevolg is van hogere opleidingseisen binnen de verschillende beroepsgroep (60\%) en niet zozeer van verschuivingen in de beroepenstructuur (40\%). Verschillende studies laten zien dat deze upgrading van het opleidingsniveau vooral het gevolg zijn van technologische ontwikkelingen (Katz en Autor, 1999) of meer complexe organisatiestructuren (Caroli en Van Reenen, 2001).

Dit soort ontwikkelingen verklaren niet alleen de skills upgrading over de afgelopen decennia, maar geven ook de noodzaak tot levenslang leren op individueel niveau weer. Technologische veranderingen kunnen de aard van de werkzaamheden veranderen en creëren een scholingsbehoefte om deze veranderingen bij te benen. Anderzijds kunnen organisatorische veranderingen ervoor zorgen dat de aard van het werk of functies veranderen waardoor er omscholing nodig is om de werkende optimaal te laten functioneren. Het merendeel van de werkenden binnen de ROA Levenslang Leren Enquête 2017, geeft aan te maken te hebben met dit soort veranderingen op het werk (Fouarge et al., 2018). Meer dan 30 procent van de werkenden geeft zelfs aan dat er grote technologische en organisatorische ontwikkelingen plaatsvinden op het werk (Fouarge et al., 2018). 
Het blijkt voor werkenden dus van groot belang om hun kennis en vaardigheden up-to-date te houden. Dit geldt voor werkenden van alle opleidingsniveaus. Door de toenemende complexiteit van het werk (Fouarge, 2017) zijn laagopgeleide werkenden echter extra kwetsbaar voor dergelijke ontwikkelingen. Daar komt bij dat laagopgeleiden beduidend minder vaak aan scholing deelnemen (39\%) dan middelbaar (53\%) en hoogopgeleiden (63\%) (ROA, 2017). Daarnaast leren zij op het werk ook minder op een informele manier (ROA, 2017). Terwijl laagopgeleiden aangeven dat ze 20 procent van hun werktijd besteden aan taken waarvan zij kunnen leren, geven hoogopgeleiden aan dat ze 28 procent van hun werktijd aan leerzame taken besteden. Ook bij de laagopgeleiden is het de vraag of de relatief geringe deelname aan werkgerelateerde leeractiviteiten het gevolg is van aanbod- (werknemer) of vraagfactoren (werkgever). Eerdere studies suggereren dat laagopgeleide werknemers andere taken en andere baankenmerken hebben waardoor de noodzaak tot leren voor de huidige functie lager is (Tamm en Görlitz, 2016), maar dat zij ook andere economische voorkeuren en andere persoonlijkheidskenmerken hebben waardoor ze minder gemotiveerd zijn om zich verder te ontwikkelen (Offerhaus, 2013; Fouarge et al., 2013). Echter, ook voor laagopgeleiden is het belangrijk dat hun skills up-to-date blijven om (breed) inzetbaar te blijven. Omdat het lastig is om beleid te ontwikkelen op basis van bovenstaande studies, gaan we in dit rapport dieper in op zowel de vraag- als aanbodfactoren die van belang zijn bij leergedrag van laagopgeleiden. Daarnaast geeft een vignetstudie inzicht in de randvoorwaarden die het aantrekkelijk kunnen maken voor zowel de werknemer als de werkgever om laagopgeleiden daadwerkelijk tot training aan te zetten.

\section{Flexibilisering van de arbeidsmarkt}

De Nederlandse arbeidsmarkt is in de afgelopen decennia ook steeds flexibeler geworden. In Figuur 1.4 is de ontwikkeling van de flexibele schil te zien sinds 2003 . We onderscheiden in de figuur twee soorten flexibele arbeidskrachten: werknemers met een flexibele arbeidsrelatie en zelfstandigen zonder personeel (zzp'ers). Voor beide soorten flexibele krachten is er een duidelijke opwaartse trend te zien. Het CPB geeft aan dat met name de meest flexibele en onzekere typen flexibele contracten (oproep-/ invalcontracten en contracten zonder vaste uren) in omvang zijn toegenomen (Bolhaar et al. 2016). Hoewel beleidsmakers de noodzaak van flexibiliteit op de arbeidsmarkt zien voor zowel werkgevers als opdrachtgevers, wordt ook gewaarschuwd voor een situatie waarin de flexibiliteit voor de werkgevers of opdrachtgevers ten koste gaat van de arbeidsmarktkansen van de werkenden en de continuïteit van het productieproces. In het Regeerakkoord 2017-2021 worden flexwerkers en zzp-ers, als ook zelfstandigen, benoemd als kwetsbare groepen op de arbeidsmarkt. 
FIGUUR 1.4 Omvang flexibele schil, 2003-2016 (x 1000 werkenden)

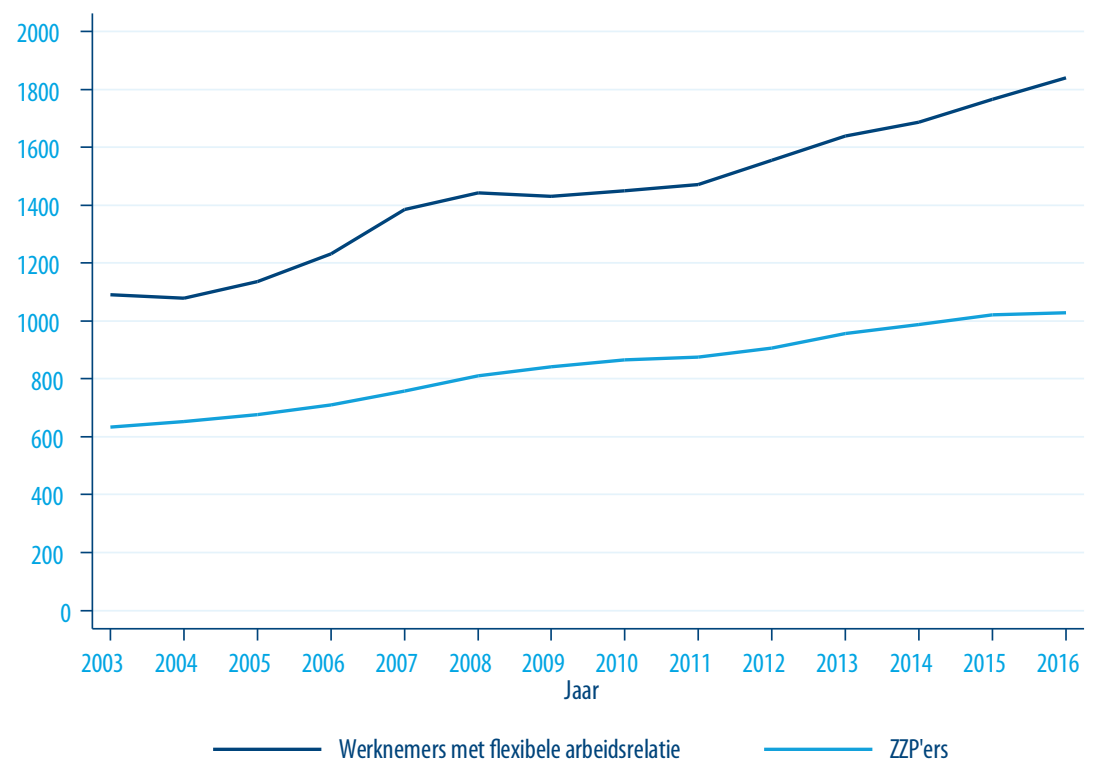

Bron: Statline 'Arbeidsdeelname; kerncijfers'

Noot: Definitie werknemers met flexibele arbeidsrelatie: Een werknemer met een arbeidsovereenkomst voor bepaalde tijd óf een flexibel aantal uren per week. Tot de werknemers met een flexibele arbeidsrelatie behoren: werknemers tijdelijk, uitzicht op vast, werknemer tijdelijk $>=1$ jaar, werknemer tijdelijk < 1 jaar, oproep/-invalkracht, uitzendkracht, werknemers vast zonder vaste uren, werknemer tijdelijk zonder vaste uren. Definitie ZZP'er: Een persoon die voor eigen rekening of risico arbeid verricht in een eigen bedrijf of praktijk (zelfstandig ondernemer) of als directeurgrootaandeelhouder en die geen personeel in dienst heeft. Overige zelfstandigen worden ook tot de zelfstandigen zonder personeel gerekend.

Hoewel flexwerk gezien kan worden als een opstapbaan, blijkt dit niet altijd het geval (Cockx en Picchio, 2012; De Graaf-Zijl et al., 2011; Dekker en Mooi-Reci, 2011). Daarnaast blijkt dat werknemers met flexibele contracten en zzp-ers minder scholing volgen dan mensen met een vast dienstverband (Fouarge et al., 2012). Een belangrijke reden die vaak genoemd wordt voor de lagere bereidheid van werkgevers om in werknemers met een tijdelijk contract te investeren, is een relatief laag rendement op trainingsinvesteringen gegeven de kortere arbeidsduur. Verschillende wetenschappelijke studies suggereren dat er inderdaad sprake is van een dergelijke, lagere bereidheid onder werkgevers om in werknemers met tijdelijke arbeidscontracten te investeren (Akgündüz en Van Huizen, 2015; Fouarge et al., 2012). In dit rapport onderzoeken we door middel van een vignetexperiment of werkgevers inderdaad minder bereid zijn om in tijdelijke werknemers te investeren en of de relatief ongunstige kosten-baten afweging een verklaring geeft voor 
de lagere bereidheid van werkgevers om in mensen met een tijdelijk contract training aan te bieden. Daarnaast bekijken we welke vraag- en aanbodfactoren kunnen helpen om een hogere trainingsparticipatie van zowel tijdelijke werknemers als van zelfstandigen te realiseren.

In het regeerakkoord stelt het kabinet voor om alle Nederlanders die een startkwalificatie hebben gehaald een individuele leerrekening te geven. Op die manier zou in theorie de scholingsdeelname van zowel oudere werknemers, laagopgeleiden, werknemers met een tijdelijk dienstverband én zzp-ers kunnen toenemen, omdat ze voor hun trainingsparticipatie minder afhankelijk zijn van hun werkgever.

Zoals hierboven werd aangegeven, kunnen verschillen in het werkgerelateerd leergedrag zowel het gevolg zijn van aanbodfactoren (bijv. preferenties en motivatie van werkenden) als ook van vraagfactoren (percepties van werkgevers bij hun kostenbaten afwegingen). De Hoofdstukken 4 en 5 van dit rapport gaan in op de bereidheid van zowel de werkenden als de werkgevers om in de training van werknemers met een kwetsbare positie op de arbeidsmarkt te investeren. Het innovatieve karakter van deze hoofdstukken levert interessante nieuwe inzichten op.

De analyses in dit rapport zijn gebaseerd op twee nieuwe datasets. Allereerst maken we gebruik van de ROA Levenslang Leren Enquête 2017. Deze enquête bouwt voort op de eerdere metingen in 2004, 2007, 2010 en 2013, met een aantal toevoegingen waaronder vragen gericht op iemands leefstijl en leefsituatie. Bovendien zijn er in de ROA Levenslang Leren Enquête 2017 ook enkele vignetstudies opgenomen die gericht zijn op het in kaart brengen van stimulerende en belemmerende factoren voor cursusdeelname. De enquête is uitgezet onder de deelnemers van het LISS panel; dit maakt het mogelijk om ook gebruik te maken van andere vragenlijsten die door dit panel ingevuld zijn.? De tweede dataset die binnen dit project ontwikkeld is, is de ROA Werkgeversenquête Scholingsbeleid. Deze enquête is in 2017 voor het eerst afgenomen en was gericht op het in kaart brengen van stimulerende en belemmerende factoren bij het aanbieden van cursussen aan mensen met een kwetsbare positie op de arbeidsmarkt.

Het leergedrag anno 2017 van 55-66 jarigen, laagopgeleiden en werknemers met een tijdelijk contract als ook van zzp'ers staat centraal in Hoofdstuk 2. In Hoofdstuk 3 worden de determinanten van het leergedrag voor deze groepen met een kwetsbare arbeidsmarktpositie geanalyseerd. Er wordt ingegaan op een breed scala aan mogelijke determinanten waaronder iemands leefstijl, leefsituatie en persoonlijkheid en het door de werkgever gevoerde HR-beleid. In Hoofdstuk 4 wordt ingegaan op de vraag hoe de cursusdeelname onder werkenden met een kwetsbare positie op de arbeidsmarkt gestimuleerd kan worden. In Hoofdstuk 5 bekijken we de bereidheid van werkgevers om cursussen aan te bieden aan deze groepen werkenden. Voor deze laatste twee hoofdstukken maken we gebruik van vignetanalyses. 


\section{WERKGERELATEERD LEERGEDRAG VAN WERKENDEN MET EEN KWETSBARE POSITIE}

In dit hoofdstuk geven wij een overzicht van het werkgerelateerd leergedrag van vier groepen werkenden met een kwetsbare arbeidsmarktpositie in 2017. Daarbij kijken we naar het formele en informele leergedrag van oudere werkenden (55-66 jaar), laagopgeleiden (vmbo-niveau of lager), werkenden met een tijdelijk arbeidscontract en zelfstandigen. In paragraaf 2.1 laten we zien in hoeverre verschillende groepen werkenden leren op het werk. Vervolgens gaat paragraaf 2.2 dieper in op de vraag wie over het algemeen het initiatief neemt tot het volgen van een cursus/training, wie de kosten draagt van deze cursus of training ${ }^{8}$ en in wiens tijd de cursus wordt gevolgd. In paragraaf 2.3 laten we de redenen zien voor het deelnemen aan cursussen. Tot slot laat paragraaf 2.4 zien in hoeverre iemands persoonlijkheid, leefstijl en leefsituatie als ook de ondersteuning door de werkgever en andere kenmerken van het werk kunnen verklaren waarom bepaalde groepen werkenden achterlopen in leergedrag.

\subsection{Formeel en informeel leren op het werk}

Binnen de ROA Levenslang Leren Enquête wordt gevraagd naar twee verschillende werkgerelateerde leervormen: cursusdeelname en informeel leren op het werk. Om de cursusdeelname in kaart te brengen zijn de respondenten gevraagd of zij in de afgelopen twee jaar een cursus of training hebben gevolgd. Het gaat hierbij om cursussen die voor het werk relevant zijn, waarbij pure hobby-cursussen (bijvoorbeeld bridge of schilderen) buiten beschouwing worden gelaten. Figuur 2.1 laat verschillen in cursus/ trainingsdeelname tussen de verschillende groepen werkenden zien. Er blijkt een negatieve relatie te zijn tussen de cursusdeelname en iemands leeftijd. Terwijl 56 procent van de 16 tot 39 jarigen een cursus/training heeft gevolgd in de 12 maanden voorafgaand aan de survey, is dit onder de 55 tot 66 jarigen maar 49 procent. De relatie tussen cursusdeelname en iemands opleidingsniveau is positief: hoe hoger opgeleid, hoe hoger de deelname aan cursussen/trainingen. Terwijl 63 procent van de hoogopgeleide werkenden een of meerdere cursussen/trainingen gevolgd heeft, is dit slechts bij 39 procent van de laagopgeleiden het geval.

8 In dit rapport maken we geen onderscheid tussen cursussen en training. Als we hierna een van deze twee termen gebruiken dan verwijzen we in alle gevallen naar zowel cursussen als trainingen. 
FIGUUR 2.1 Cursusdeelname naar type werkenden (\%)

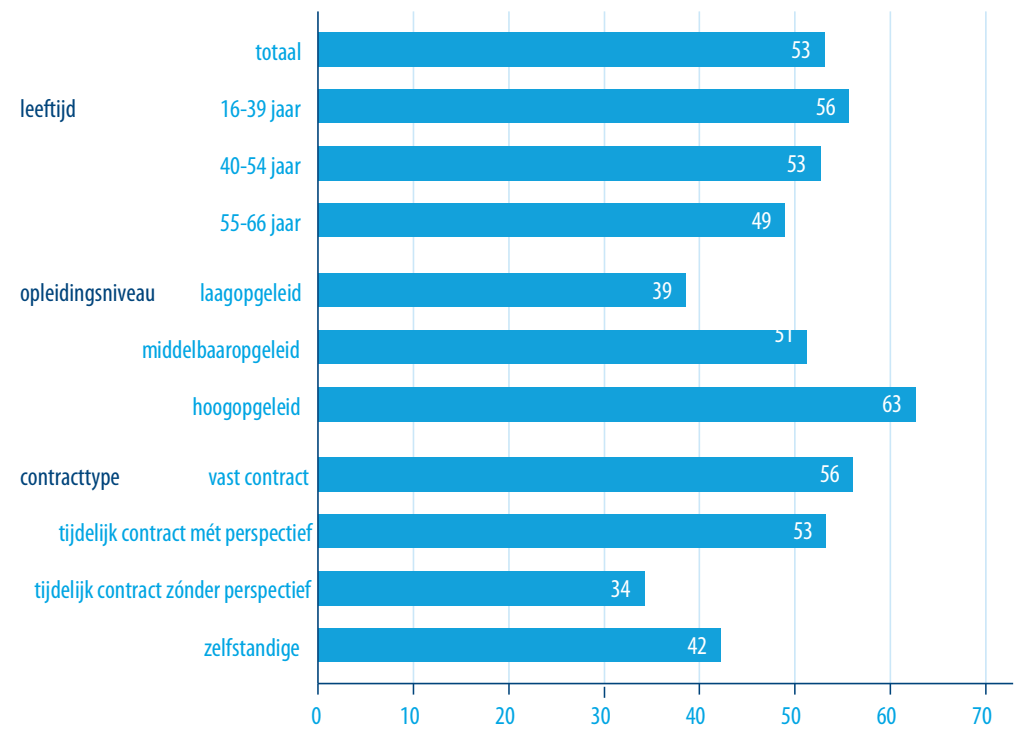

Bron: ROA LLL Enquête, 2017

Minder dan de helft van de 55 tot 66 jarigen, van de laagopgeleiden, van de werknemers met een tijdelijk contract zonder zicht op vast én van de zelfstandigen heeft in de afgelopen twee jaar een werkgerelateerde cursus gevolgd.
Met betrekking tot het soort dienstverband, laat de figuur zien dat mensen met een vast contract gemiddeld het vaakst aan een cursus deelnemen: 56 procent van alle mensen met een vast contract heeft in de afgelopen twee jaar een werkgerelateerde cursus gevolgd. Dit is vergelijkbaar met de cursusdeelname van de werknemers met een tijdelijk contract met uitzicht op vast werk (53\%). Bij de werknemers met een tijdelijk contract zonder uitzicht op een vaste baan ligt de cursusdeelname een stuk lager (34\%), terwijl 42 procent van de zelfstandigen in de afgelopen twee jaar een training heeft gevolgd.

Werkenden leren niet enkel van cursussen, maar ook van de taken die zij uitoefenen (Arrow, 1962). Voor het meten van het informeel leren op het werk worden respondenten in de ROA Levenslang Leren Enquête gevraagd hoeveel procent van hun werktijd zij besteden aan taken waarvan zij kunnen leren. ${ }^{9}$ In Figuur 2.2 is dit percentage voor de verschillende groepen werkenden weergegeven. Uit de figuur maken we op dat hoe ouder men is, hoe minder men leert van de taken die men uitvoert. Dit is in lijn met eerdere bevindingen (Borghans et al. 2014). 55 tot 66 jarigen geven aan dat zij ongeveer één vijfde van hun werktijd besteden aan taken

$\quad$ Zie Borghans et al. (2006) voor een verantwoording van de meting van informeel leren. 
waarvan zij kunnen leren. Voor 16 tot 39 jarigen is dit percentage significant hoger (27\%). Het verschil in informeel leren op het werk tussen mensen met een lage en middelbare opleiding is verwaarloosbaar. Beide groepen werkenden besteden ongeveer één vijfde van hun werktijd aan taken waarvan ze kunnen leren. Hoogopgeleiden besteden procentueel gezien significant meer tijd aan taken waarvan zij kunnen leren (28\%), wellicht omdat hun werktaken complexer van aard zijn (Fouarge \& De Grip, 2013). Werknemers met een vast contract leren minder van hun werk dan werknemers met een tijdelijk dienstverband. Dit kan te maken hebben met de relatief korte tijd die werknemers met een tijdelijk dienstverband in de huidige functie werkzaam zijn. ${ }^{10}$ Zelfstandigen geven aan ongeveer een kwart van hun werktijd te besteden aan taken waarvan zij kunnen leren.

FIGUUR 2.2 Informeel leren op het werk in procenten van de werktijd naar type werkenden (\%)

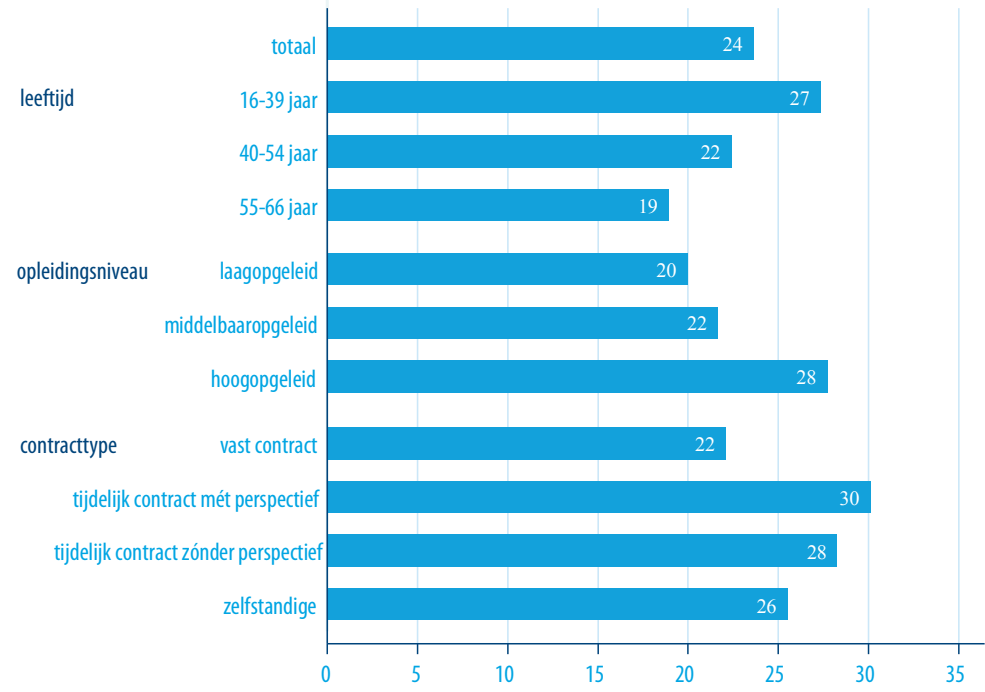

Bron: ROA LLL Enquête, 2017

10 In Hoofdstuk 3 komen we hier op terug. 


\subsection{Wie bepaalt en wie betaalt voor cursussen?}

Wie neemt het initiatief tot het volgen van een cursus/training, wie financiert de cursus en in wiens tijd wordt de cursus gevolgd? De figuren 2.3-2.5 geven een antwoord op deze vragen."

\section{Initiatief}

In Figuur 2.3 staat het initiatief tot het volgen van de cursus centraal. Hierbij valt het op dat de oudste leeftijdsgroep significant vaker het initiatief neemt voor het volgen het volgen van een cursus dan de jongste leeftijdsgroep. Dit verschil is echter niet significant. Ook blijkt dat het volgen van een cursus minder vaak een gezamenlijk initiatief is van de werkgever en werknemer naarmate de leeftijd van de werknemer hoger is. Daarbij is overigens wel alleen het verschil tussen de jongste en oudste leeftijdscategorie significant.

Laagopgeleiden nemen minder vaak het initiatief om aan een cursus deel te nemen dan hoogopgeleiden. Werknemers met een tijdelijk contract zonder uitzicht op vast werk nemen juist vaak zelf het initiatief.
Als we werkenden vergelijken op basis van hun opleidingsniveau, dan valt het vooral op dat cursussen door lager opgeleiden veel minder vaak op eigen initiatief worden gevolgd dan onder hoger opgeleiden. Onder laagopgeleide werkenden ligt het initiatief in iets minder dan één op de drie gevallen bij de

werkende zelf, terwijl het initiatief bij hoogopgeleiden in bijna de helft van de gevallen bij de werkende zelf ligt. Bij de laagopgeleiden neemt de werkgever meestal het initiatief (44\%); bij de hoogopgeleiden ligt het initiatief slechts bij een kwart van de gevolgde cursussen bij de werkgever. Bij middelbaaropgeleiden ligt het initiatief even vaak bij de werkgever als bij de werkende zelf. Onder middelbaar- en hoogopgeleide werkenden is het initiatief daarnaast iets vaker een gezamenlijke inspanning van werkgever en werknemer en komt het initiatief ook iets minder vaak vanuit het UWV Werkbedrijf/de sociale dienst, maar deze percentages ontlopen elkaar niet veel. 'overig' zijn eveneens weggelaten. 
FIGUUR 2.3 Initiatief van de cursus, naar subgroep (\%)

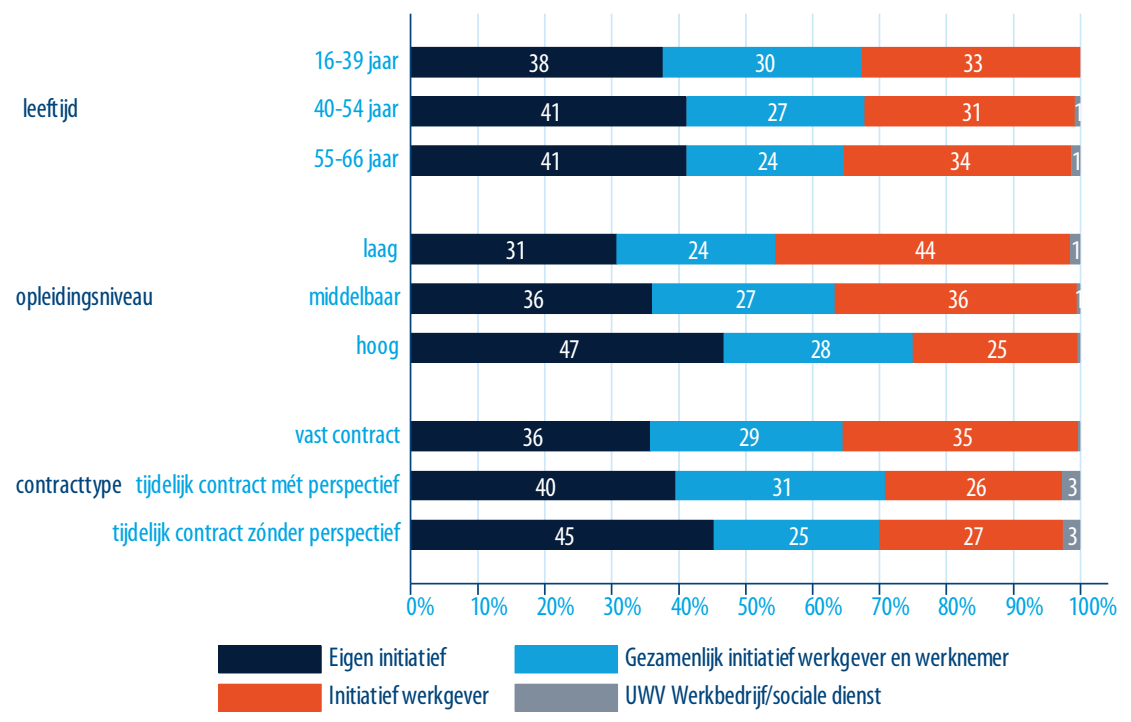

Bron: ROA LLL Enquête, 2017

Als we kijken naar de arbeidscontracten van de werkenden, dan valt het op dat het initiatief tot het volgen van een cursus vaker bij de werkende zelf ligt als deze géén vaste aanstelling heeft. Hoe onzekerder de aanstelling, des te vaker de cursus dus op eigen initiatief wordt gevolgd. Werkgevers nemen bij tijdelijke werknemers minder vaak het initiatief. Slechts in ongeveer een kwart van de gevallen namen de werkgevers het initiatief. Daarbij is er geen significant verschil tussen de tijdelijke krachten die perspectief hebben op een vaste aanstelling en degenen zonder perspectief op een vaste baan. Bij de werkenden met een tijdelijke aanstelling zonder perspectief op een vaste aanstelling zijn de gevolgde cursussen wel veel minder vaak een gezamenlijk initiatief van de werkgever en werknemer dan bij de tijdelijke medewerkers die perspectief op vast werk hebben. Tot slot geldt dat bij werkenden met een tijdelijke aanstelling de gevolgde cursussen vaker het initiatief zijn geweest van het UWV Werkbedrijf of de sociale dienst.

\section{Bekostiging}

In Figuur 2.4 zoomen we in op de bekostiging van de cursus. De figuur laat duidelijk zien dat dat de werkgever voor alle groepen werkenden de meeste cursussen bekostigt. Van duidelijke verschillen tussen werkenden in de verschillende leeftijdsgroepen blijkt geen sprake te zijn. De 40-54 jarigen draaien iets vaker zelf voor de kosten op, maar dit verschil blijkt niet statistisch significant. 
Ook de verschillen tussen de verschillende opleidingsniveaus zijn verwaarloosbaar klein. Voor alle opleidingsniveaus betaalt de werkgever ruim 80 procent van de gevolgde cursussen en draait de werknemer zelf in ongeveer 13 procent van de gevallen voor de kosten op. Bij twee procent van de cursussen worden de kosten gedeeld en in slechts één (middelbaar- en hoogopgeleiden) tot twee procent (laagopgeleiden) van de gevallen bekostigd door het UWV Werkbedrijf of de sociale dienst.

FIGUUR 2.4 Financiering van de cursus, naar subgroep (\%)

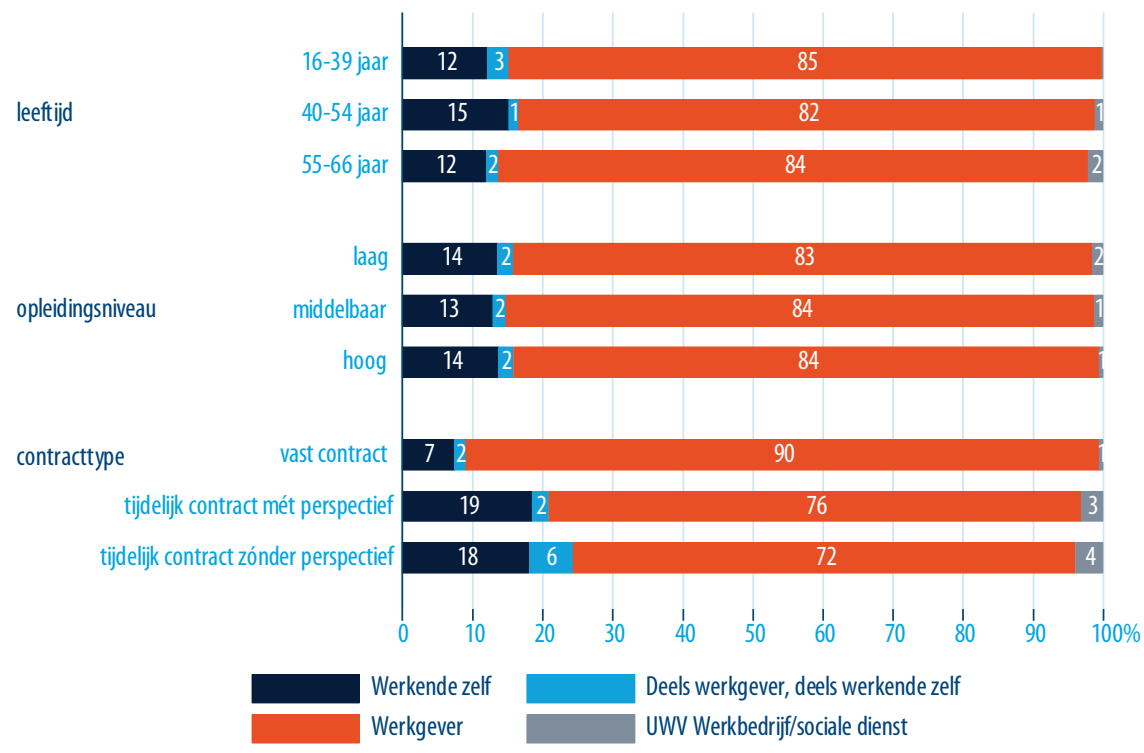

Bron: ROA LLL Enquête, 2017.

Werknemers met een tijdelijk contract betalen veel vaker zelf de training dan werknemers met een vaste baan.
Waar de verschillen in de bekostiging tussen de opleidingsniveaus en leeftijdsgroepen verwaarloosbaar klein zijn, geldt dat zeker niet voor werkenden met verschillende

contracttypes. Zo blijkt dat slechts 7 procent van de werkenden met een vast contract zelf de cursuskosten betalen, terwijl dit bij bijna één op de vijf werkenden met een tijdelijke aanstelling het geval is. Vooral werkenden met een tijdelijke aanstelling zonder perspectief op een vaste aanstelling zijn hier benadeeld: Zij draaien in bijna een kwart van de gevallen (24\%) volledig of gedeeltelijk voor de cursuskosten op. Uit eerder onderzoek weten wij dat het zelf bekostigen van cursussen door werkenden met flexibele contracten nauwelijks compenseert voor het verschil in door de werkgever bekostigde scholing (Fouarge et al., 2012). Dit blijk in deze survey ook het geval, gezien de in Figuur 2.1 genoteerde verschillen in cursusparticipatie. 


\section{Cursus in werk- en eigen tijd}

Figuur 2.5 geeft voor de verschillende subgroepen aan in welke mate de cursussen onder werktijd dan wel in eigen tijd gevolgd zijn. Tussen de verschillende leeftijdsgroepen lijken er kleine verschillen te zijn in de mate waarin de cursus tijdens werktijd heeft plaatsgevonden, maar deze blijken niet altijd statistisch significant te zijn: Allereerst valt op dat het aandeel werkenden dat de cursus volledig onder werktijd mocht volgen niet significant afwijkt tussen de verschillende leeftijdsgroepen. Het enige significante verschil is gevonden tussen 16-39 jarigen en 40-55 jarigen als het gaat om het volledig in eigen tijd volgen van een cursus. De 16-39 jarigen volgen significant minder vaak een cursus geheel in eigen tijd vergeleken met de andere leeftijdscategorieën.

FIGUUR 2.5 Tijd waarin de cursus werd gevolgd, naar subgroep (\%)

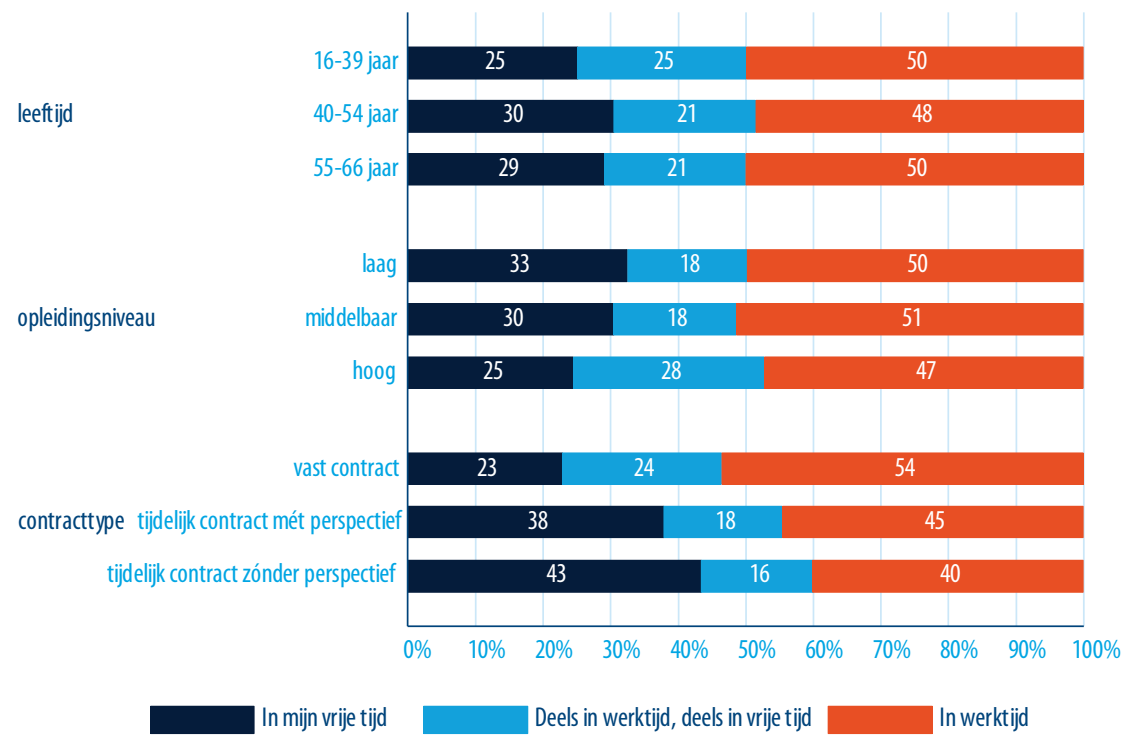

Bron: ROA LLL Enquête, 2017

Laagopgeleiden en werknemers met een tijdelijk contract volgen hun trainingen vaker in hun vrije tijd dan hoogopgeleide werknemers of werknemers met een vaste baan.
Laagopgeleiden blijken hun cursus vaker in hun eigen tijd te volgen dan middelbaar en vooral hoger opgeleiden. Hoogopgeleiden volgen de cursus juist vaker deels in eigen tijd en deels onder werktijd. Net als bij de financiering van de cursussen, zijn de verschillen in de tijd waarin de cursussen worden gevolgd het grootst tussen de mensen met verschillende arbeidscontracten. Terwijl slechts 23 procent van de werkenden in vaste dienst de cursus volledig in eigen tijd heeft gevolgd, is dit voor werkenden met 
een tijdelijke aanstelling mét perspectief op een vaste aanstelling 28 procent en voor degenen zonder perspectief op een vaste aanstelling maar liefst 43 procent.

\subsection{Redenen voor het volgen van een cursus}

Aan de werkenden die in de afgelopen twee jaar een cursus hebben gevolgd is in de ROA Levenslang Leren Enquête gevraagd waarom zij deze cursus hebben gevolgd. In Tabel 2.1 staat de top 3 van de belangrijkste redenen voor het volgen van een cursus voor de verschillende groepen werkenden genoemd met tussen haakjes het percentage dat deze reden noemde.

Bij alle in Tabel 2.1 onderscheiden groepen is het verbeteren van de bestaande kennis en vaardigheden het vaakst genoemd als reden om de cursus te volgen. Het verplichte karakter van de cursus komt in de top drie van de genoemde redenen voor alle leeftijdsgroepen. Als we inzoomen op de drie leeftijdsgroepen, dan valt op dat het realiseren van de loopbaandoeleinden door de oudste leeftijdscategorie niet in de top drie te vinden is, terwijl het voor de jongste leeftijdscategorie op de tweede plek staat, en de middelste leeftijdscategorie op de derde plek. Voor oudere werkenden ( $55 \mathrm{t} / \mathrm{m} 66$ jaar) is een nieuwe manier van werken die geïntroduceerd werd op het werk een belangrijke reden voor het volgens van een cursus, maar dit motief maakt geen deel uit van de top drie van de andere leeftijdsgroepen.

De drie meest genoemde redenen voor het volgen van de cursus zijn voor alle opleidingsniveaus hetzelfde. Het verbeteren van iemand kennis en vaardigheden is voor alle opleidingsniveaus de belangrijkste reden om een cursus te volgen. Bij de laag- en middelbaaropgeleiden is het verplichte karakter van de cursus de op één na meest genoemde reden voor het volgen van de cursus en staat het realiseren van loopbaandoeleinden op de derde plaatst. Voor hoogopgeleiden is de volgorde precies andersom.

Als we kijken naar het type arbeidscontract van de werkenden, dan zien we dat het verbeteren van iemands kennis en vaardigheden weliswaar voor alle contractvormen op de eerste plek staat, maar dat deze reden minder vaak wordt genoemd naarmate de aanstelling onzekerder is. Werkenden met een tijdelijke aanstelling zónder perspectief op een vaste aanstelling blijken relatief vaak een cursus te volgen om hun kansen op een andere baan te vergroten. Ter vergelijking: Bij werkenden met een vaste aanstelling staat deze reden pas op een 7e plek en bij werkenden met een tijdelijke aanstelling waarbij wél sprake is van het perspectief op een vaste aanstelling op de 4e plek. Interessant is ook dat werkenden met een tijdelijke aanstelling die perspectief hebben op een vaste aanstelling het volgen van een cursus vaak verplicht is. Dit suggereert dat de werkgever deze medewerkers op het vereiste niveau voor een goede functievervulling wil brengen. 
TABEL 2.1 Top 3 van redenen voor het volgen van een cursus/training naar type werknemers

\begin{tabular}{|c|c|c|c|}
\hline \multicolumn{4}{|c|}{ Paneel a. Naar leeftijd } \\
\hline & $16 \mathrm{t} / \mathrm{m} 39 \mathrm{jaar}$ & $40 \mathrm{t} / \mathrm{m} 54$ jaar & $55 \mathrm{t} / \mathrm{m} 66$ jaar \\
\hline 1 & $\begin{array}{l}\text { Verbeteren kennis en vaardigheden } \\
(77 \%)\end{array}$ & $\begin{array}{l}\text { Verbeteren kennis en vaardigheden } \\
(82 \%)\end{array}$ & $\begin{array}{l}\text { Verbeteren kennis en vaardigheden } \\
(83 \%)\end{array}$ \\
\hline 2 & Loopbaan (45\%) & Verplicht (42\%) & Verplicht (48\%) \\
\hline 3 & Verplicht (37\%) & Loopbaan (30\%) & Nieuwe manier van werken (31\%) \\
\hline & \multicolumn{3}{|c|}{ Paneel b. Naar opleidingsniveau } \\
\hline & Laag & Middelbaar & Hoog \\
\hline 1 & $\begin{array}{l}\text { Verbeteren kennis en vaardigheden } \\
(77 \%)\end{array}$ & $\begin{array}{l}\text { Verbeteren kennis en vaardigheden } \\
(74 \%)\end{array}$ & $\begin{array}{l}\text { Verbeteren kennis en vaardigheden } \\
(86 \%)\end{array}$ \\
\hline 2 & Verplicht (51\%) & Verplicht (46\%) & Loopbaan (37\%) \\
\hline \multirow[t]{3}{*}{3} & Loopbaan (40\%) & Loopbaan (33\%) & Verplicht (33\%) \\
\hline & \multicolumn{3}{|c|}{ Paneel c. Naar type contract } \\
\hline & Vast contract & Tijdelijk contract mét perspectief & Tijdelijk contract zónder perspectief \\
\hline 1 & $\begin{array}{l}\text { Verbeteren kennis en vaardigheden } \\
(82 \%)\end{array}$ & $\begin{array}{l}\text { Verbeteren kennis en vaardigheden } \\
(68 \%)\end{array}$ & $\begin{array}{l}\text { Verbeteren kennis en vaardigheden } \\
(67 \%)\end{array}$ \\
\hline 2 & Verplicht (41\%) & Loopbaan (45\%) & $\begin{array}{l}\text { Mogelijkheden andere baan vergroten } \\
(53 \%)\end{array}$ \\
\hline 3 & Loopbaan (34\%) & Verplicht (40\%) & Loopbaan (47\%) \\
\hline
\end{tabular}

Bron: ROA LLL Enquête, 2017

Voor werknemers met een tijdelijk dienstverband kan het verhogen van de kans op een vaste aanstelling een belangrijke reden zijn om een cursus te volgen. Daarom is aan werknemers met een tijdelijk dienstverband gevraagd of zij de cursus hebben gevolgd om hun kans op een vaste aanstelling te vergroten. Dit werd beaamd door 36 procent van de werknemers met een tijdelijk dienstverband met uitzicht op een vast contract en 51 procent van de medewerkers zonder uitzicht op een vaste baan. ${ }^{12}$

Voor zelfstandigen kunnen heel andere redenen een rol spelen bij het volgen van een cursus of training dan bij werknemers die in loondienst zijn. Om hier rekening mee te houden zijn in de ROA Levenslang Leren Enquête enkele potentiële redenen die voor deze groep belangrijk zouden kunnen zijn opgenomen: het verhogen van de omzet (door 29 procent aangegeven als reden), het verkrijgen van andere soorten klanten (31\%) en om meer kwaliteit te kunnen leveren (69\%). Van de drie redenen die specifiek voor zelfstandigen zijn toegevoegd komt alleen de laatstgenoemde in de top 3 voor, namelijk

12 Dit zou neergekomen zijn op een derde plek in Tabel 2.1 (paneel c) voor de werknemers met een 'tijdelijk met' contract en op een tweede plek voor de werknemers met een 'tijdelijk zonder' contract. Omdat deze vraag echter alleen aan werknemers met een tijdelijk arbeidscontract is gevraagd, hebben we ervoor gekozen deze redenen geen onderdeel te maken van Tabel 2.1. 
op plek 2. Net als bij alle andere groepen werknemers staat het verbeteren van kennis en vaardigheden op de eerste plek (88\%). Op plek drie staat tot slot het realiseren van loopbaandoeleinden (44\%).

\subsection{Het verschil in leren verklaard}

In de Figuren 2.1-2.2 is het verschil in het werkgerelateerde leren voor de verschillende groepen werkenden in beeld gebracht. De daar genoteerde verschillen hangen voor een deel samen met verschillen in andere belangrijke kenmerken van de werkenden. Zo wordt het verschil tussen de deelname aan cursussen onder laag- en hoogopgeleide werknemers gedeeltelijk verklaard doordat laagopgeleide werknemers over het algemeen minder uren per week werken en er een negatieve relatie bestaat tussen de omvang van het contract en de kans op cursusdeelname (Nelen \& De Grip 2009).

In deze paragraaf bespreken wij de verschillen in het werkgerelateerde leren tussen de onderscheiden groepen werkenden (naar leeftijd, opleidingsniveau en type contract). In onze analyses corrigeren we daarbij voor de volgende kenmerken van werkenden en hun banen: ${ }^{13}$

$\begin{array}{ll}\text { 1. } & \text { Persoons- en baankenmerken } \\ \text { 2. } & \text { Kenmerken op het gebied van leefstijl en leefsituatie } \\ \text { 3. } & \text { Persoonlijkheid } \\ \text { 4. Inhoud werk } \\ \text { 5. HR-beleid }\end{array}$

\section{Persoons- en baankenmerken}

De standaard persoonskenmerken die meegenomen worden in de analyse zijn geselecteerd aan de hand van de wetenschappelijke literatuur die ingaat op het verklaren van werkgerelateerd leergedrag (zie bijvoorbeeld Bates, 2001 en Nelen \& de Grip, 2009). Daarbij kijken we naar iemands leeftijd, geslacht en opleidingsniveau. Daarnaast corrigeren we voor de gewerkte uren (volgens contract voor mensen in loondienst en het feitelijk gewerkte aantal uren voor zelfstandigen) en het aantal jaren dat men werkzaam is in de huidige functie/ als zelfstandige. Ook wordt de aard van het arbeidscontract meegenomen. ${ }^{14}$

\section{Kenmerken op het gebied van leefstijl en leefsituatie}

We analyseren in hoeverre iemands leefstijl en leefsituatie bepalend zijn voor het verschil in leergedrag tussen groepen werkenden. Leefstijl wordt in de analyses meegenomen door rekening te houden met het rook- en drinkgedrag. Daarnaast wordt iemands body-

13 In Bijlage A, Tabel A3 is per variabele ook de bron meegenomen die gebruikt is om de desbetreffende variabele in de vragenlijst te meten.

14 In de analyses waarin we het verschil in leren naar leeftijd verklaren, controleren we voor opleidingsniveau en contracttype. Wanneer we verschillen in leren naar opleidingsniveau verklaren, controleren we voor leeftijd en contracttype. Wanneer we verschillen in leren naar contracttype verklaren controleren we voor leeftijd en opleidingsniveau. 
mass index (BMI) meegenomen. Wanneer werkenden met een bepaalde leefstijl meer of minder waarde zouden hechten aan hun carrière, dan zou dit een verschil in deelname aan het werkgerelateerde leren kunnen verklaren. De leefsituatie wordt meegenomen door twee controlevariabelen: de woonvorm van het huishouden (alleenstaand, (on) gehuwd samenwonend zonder kinderen, (on)gehuwd samenwonend met kinderen, alleenstaand met kinderen, of anders) en het aantal kinderen in het huishouden. De leefsituatie geeft een indicatie van de beschikbare tijd die men naast het werk heeft om zich te richten op een leven lang leren.

\section{Persoonlijkheid}

We weten vanuit de wetenschappelijke literatuur dat persoonlijkheid en economische voorkeuren medebepalend zijn voor de verklaring van verschillen in het leergedrag tussen verschillende groepen werkenden (bv. Fouarge et al., 2013; Offerhaus 2013). De volgende persoonlijkheidsindicatoren worden meegenomen:

- Examenvrees

- Besluiteloosheid

- Bevlogenheid

- Positieve reciprociteit

- Vertrouwen

- Big 5 persoonlijkheidskenmerken: extraversie, service gerichtheid, zorgvuldigheid, emotionele stabiliteit, open houding t.o.v. nieuwe ervaringen.

Ook worden twee economische voorkeuren meegenomen:

- Risicovoorkeur

- Tijdsvoorkeur

In Bijlage A (Tabel A.3) wordt per indicator aangegeven hoe (en waar) deze gemeten is en welke gevalideerde schaal gebruikt is.

\section{Inhoud werk}

De inhoud van het werk bepaalt de mate waarin het nodig is om aan werkgerelateerde leeractiviteiten deel te nemen om vaardigheden up-to-date te houden of iemand (breed) inzetbaar te houden (Nelen, 2012). Er zijn in deze context vier variabelen in de analyse opgenomen die betrekking hebben op de werkomgeving:

- Mate van organisatorische ontwikkelingen die de inhoud van het werk veranderen.

- Mate van technologische ontwikkelingen die de inhoud van het werk veranderen.

- Mate van concurrentie in de markt waarin het bedrijf opereert.

- Mate van stabiliteit in de vraag in de markt waarin het bedrijf opereert. 
Daarnaast nemen we expliciet het takenpakket van werkenden mee. We onderscheiden de volgende taken: ${ }^{15}$

- Interpersoonlijke vaardigheden

- Rekenvaardigheden

- Taal vaardigheden

- Fysieke kracht

- Probleemoplossend vermogen

- Plannen en organiseren

- Kennis van organisatie

- Gebruik van computer

\section{HR-beleid}

Uit Nelen \& De Grip (2009) bleek dat deeltijd- en voltijdwerkenden niet op eenzelfde manier door het HR-beleid van hun werkgever gestimuleerd werden tot trainingsdeelname en informeel leren op het werk. We nemen daarom ook hier de volgende HR-instrumenten in de analyse mee:

- Functionerings- en/of beoordelingsgesprekken

- Persoonlijk opleidings- of ontwikkelingsplanplan (POP)

- Regelmatige feedback van uw leidinggevende

- Regelmatige feedback door collega's

- Loopbaanplan

- Coaching

- Functieroulatie

- Taakroulatie

- Detachering bij andere afdelingen binnen dezelfde organisatie

- Prestatiebeloning of bonussen

Alle werkenden in loondienst hebben in de ROA Levenslang Leren Enquête aangegeven welke deze van HR-instrumenten door hun werkgever ingezet worden om hun functioneren en/of loopbaanontwikkeling te stimuleren. ${ }^{16}$ Daarnaast wordteen variabelemeegenomen dieinzichtgeeftin het leerklimaat in deorganisatie waarin iemand werkzaam is. Deze schaal is ontwikkeld door Leufvén et al. (2015). ${ }^{17}$

15 De informatie over iemands takenpakket komt uit de tweede peiling van de Nederlandse Skills Survey (NSS). In de NSS worden de respondenten gevraagd om voor een 35-tal taken aan te geven in hoeverre deze taken belangrijk zijn in het huidige werk. Deze 35 taken aggregeren we vervolgens in een achttal groepen taken zoals te zien is in Bijlage A (Tabel A.4). In de tabel is te zien welke taken onder welke groep vallen. De taken zijn bij elkaar gezet door het gemiddelde van de taken per taakgroep uit te rekenen.

16 Voor de zelfstandigen is hier een aparte antwoordcategorie n.v.t. geconstrueerd.

17 Wij hebben gekozen om een tweetal dimensies uit te vragen: (1) 'dialogue and inquiry' en (2) 'continuous learning'. 
Het verschil in trainingsparticipatie tussen verschillende leeftijdsgroepen blijkt volledig te wijten aan verschillen in opleidingsachtergrond, het aantal uren dat men werkzaam is en het type dienstverband.

In Tabel 2.2 wordt weergegeven in hoeverre het verschil tussen het werkgerelateerde leergedrag van werknemers in verschillende leeftijdsgroepen verklaard kan worden door de verschillende persoons-, en werkkenmerken. De eerste kolom geeft een overzicht van de schattingsresultaten van een regressieanalyse waarin alleen de leeftijdsgroepen zijn meegenomen. ${ }^{18}$ De coëfficiënten geven daarmee het pure verschil in cursusparticipatie ten opzichte van de 16-39 jarigen weer. Uit de tabel blijkt dat werkenden tussen de 40 en 55 jaar niet significant minder vaak een training volgen dan de 16-39 jarigen. ${ }^{19}$ Voor 55-66 jarigen is er wel sprake van een significant kleinere cursusdeelname. Voor hen is de cursusparticipatie bijna 7,5 procent lager dan bij 16-39 jarigen. Echter, zodra we corrigeren voor de andere persoons- en werkomgevingskenmerkencursusparticipatie, verdwijnt het significante verschil in cursusparticipatie tussen de oudste en jongste leeftijdsgroep. Dit wijst erop dat het niet de leeftijd per se is waardoor de oudere leeftijdsgroep minder trainingen volgt. Dit komt vooral door de significant positieve relatie tussen cursusparticipatie en iemands opleidingsniveau en het aantal uren dat iemand werkt. Dit is in lijn met de bevindingen van Nelen \& De Grip (2009). ${ }^{20}$

TABEL 2.2 Verschil in cursusdeelname naar leeftijd

\begin{tabular}{|l|c|c|c|c|c|c|}
\hline Cursusdeelname & $(1)$ & $(2)$ & $(3)$ & $(4)$ & $(5)$ & (6) \\
\hline 16-39 jarigen & ref & ref & ref & ref & ref & ref \\
\hline 40-54 jarigen & $-0,040$ & 0,010 & 0,010 & $-0,005$ & $-0,001$ & 0,002 \\
\hline $55-66$ jarigen & $-0,073^{* *}$ & 0,003 & $-0,001$ & $-0,025$ & $-0,030$ & $-0,028$ \\
\hline Controle-variabelen & nee & ja & ja & ja & ja & ja \\
\hline Leefstijl en leefsituatie & nee & nee & ja & ja & ja & ja \\
\hline Persoonlijkheid & nee & nee & nee & ja & ja & ja \\
\hline Inhoud werk & nee & nee & nee & nee & ja & ja \\
\hline HR-beleid & nee & nee & nee & nee & nee & ja
\end{tabular}

Bronnen: ROA LLL Enquête, 2017; NSS 2017; LISS, 2014-2017

18 Voor een goede vergelijking van de kolommen moet het aantal observaties gelijk blijven tussen de 6 specificaties. Dit heeft als gevolg dat we alleen respondenten meenemen die ook de NSS hebben ingevuld. Dit kan er toe leiden dat kolom 1 niet precies dezelfde resultaten toont als de beschrijvende statistieken aan het begin van dit hoofdstuk.

19 Dit in tegenstelling tot de beschrijvende statistieken aan het begin van dit hoofdstuk.

20 Er blijkt echter geen verschil te zijn in de cursusdeelname van mannen en vrouwen. Ook het aantal jaren dat men werkzaam is in de huidige functie (of als zelfstandige werkt) is niet gerelateerd aan de cursusdeelname. 
Het trainingsverschil tussen laag- en hoogopgeleiden kan voor bijna 50\% verklaard worden door een andere werkinhoud. Het betreft dan onder andere een verschil in takenpakket.
In Tabel 2.3 gaan we in op het verschil in deelname aan werkgerelateerde cursussen tussen werkenden met verschillende opleidingsniveaus. Uit kolom 1 blijkt dat laagopgeleiden 25 procent minder vaak een cursus hebben gevolgd dan hoogopgeleiden. Voor middelbaar opgeleiden is het verschil kleiner, 13 procent, maar evengoed significant. Het toevoegen van standaard controlevariabelen verandert niets aan deze verschillen. Dit geldt ook voor het opnemen van de leefstijl en leefsituatie variabelen (kolom 3). De cursusparticipatie blijkt overigens sowieso nauwelijks gerelateerd te zijn aan iemands leefstijl en leefsituatie. We vinden alleen dat (on)gehuwd samenwonende werkenden zonder kinderen een significant hogere kans hebben op trainingsdeelname dan alleenstaanden zonder kinderen.

TABEL 2.3 Verschil in cursusdeelname naar opleidingsniveau

\begin{tabular}{|l|c|c|c|c|c|c|}
\hline Cursusdeelname & $(1)$ & $(2)$ & $(3)$ & $(4)$ & $(5)$ & (6) \\
\hline Laagopgeleiden & $-0,245^{* * *}$ & $-0,225^{* * *}$ & $-0,230^{* * *}$ & $-0,207^{* *}$ & $-0,132^{* * *}$ & $-0,130^{* * *}$ \\
\hline Middelbaar opgeleiden & $-0,130^{* * *}$ & $-0,121^{* * *}$ & $-0,124^{* * *}$ & $-0,114^{* * *}$ & $-0,079^{* * *}$ & $-0,080^{* * *}$ \\
\hline Hoogopgeleiden & ref & ref & ref & ref & ref & ref \\
\hline Controle- variabelen & nee & ja & ja & ja & ja & ja \\
\hline Leefstijl en leefsituatie & nee & nee & ja & ja & ja & ja \\
\hline Persoonlijkheid & nee & nee & nee & ja & ja & ja \\
\hline Inhoud werk & nee & nee & nee & nee & ja & ja \\
\hline HR-beleid & nee & nee & nee & nee & nee & ja
\end{tabular}

Bronnen: ROA LLL Enquête, 2017; NSS 2017; LISS, 2014-2017

Ook het meenemen van de verschillende facetten van iemands persoonlijkheid doet weinig met de trainingsverschillen tussen de werkenden met verschillende opleidingsniveaus (zie kolom 4). Met name de coëfficiënt van laagopgeleiden neemt wat af, maar deze afname is niet statistisch significant. Er zijn desondanks wel enkele persoonlijkheidsfactoren die positief gerelateerd blijken te zijn aan iemands trainingsdeelname. Het gaat dan om bevlogenheid, nauwkeurigheid en vertrouwen.21

In kolom 5 wordt gecorrigeerd voor de inhoud van het werk. Hierdoor neemt het verschil in cursusparticipatie tussen laag- en middelbaaropgeleiden aan de ene kant en hoogopgeleiden aan de andere kant significant af. Laagopgeleiden hebben weliswaar nog steeds een significant kleinere kans om aan training deelgenomen te hebben, maar het verschil is niet langer 25 procent, maar 13 procent. Ook het verschil tussen middelbaar en hoogopgeleiden neemt significant af tot 8 procent. Deze afnames lijken met name gedreven door organisatorische veranderingen, de concurrentie op de markt waarop het bedrijf opereert en het hebben van een aantal taken: interpersoonlijke vaardig-

21 Opvallend genoeg vinden we geen significante relatie tussen examenvrees en trainingsdeelname. Fouarge et al. (2013) vonden dit wel. 
heden, taalvaardigheden, plannen en organiseren en het gebruik van computers. De eerste twee genoemde taken blijken positief gerelateerd te zijn aan cursusdeelname en de laatstgenoemde twee taken negatief.

Het toevoegen van het HR-beleid in kolom 6 leidt niet tot een verdere afname in het trainingsverschil tussen laag-, middelbaar en hoogopgeleiden.

TABEL 2.4 Verschil in cursusdeelname naar type arbeidscontract

\begin{tabular}{|l|c|c|c|c|c|c|}
\hline Cursusdeelname & $(1)$ & $(2)$ & $(3)$ & $(4)$ & (5) & (6) \\
\hline Vast contract & ref & ref & ref & ref & ref & ref \\
\hline Tijdelijk contract met perspectief & $-0,000$ & $-0,015$ & $-0,016$ & $-0,022$ & 0,004 & $-0,002$ \\
\hline Tijdelijk contract zonder perspectief & $-0,153^{* * *}$ & $-0,127^{* *}$ & $-0,128^{* *}$ & $-0,117^{* *}$ & $-0,086$ & $-0,063$ \\
\hline Zelfstandigen & $-0,147^{* * *}$ & $-0,152^{* * *}$ & $-0,157^{* * *}$ & $-0,169^{* * *}$ & $-0,076^{*}$ & \\
\hline Controle- variabelen & nee & ja & ja & ja & ja & ja \\
\hline Leefstijl en leefsituatie & nee & nee & ja & ja & ja & ja \\
\hline Persoonlijkheid & nee & nee & nee & ja & ja & ja \\
\hline Inhoud werk & nee & nee & nee & nee & ja & ja \\
\hline HR-beleid & nee & nee & nee & nee & nee & ja \\
\hline
\end{tabular}

Bronnen: ROA LLL Enquête, 2017; NSS 2017; LISS, 2014-2017

Noot: In kolom (6) zijn de zelfstandigen weggelaten in verband met gebrek aan informatie over de ingezette HR-instrumenten.

De lagere trainingsparticipatie onder werknemers met een tijdelijk dienstverband zonder perspectief op een vast dienstverband kan voor een relatief groot deel worden verklaard door de inhoud van het werk en de context waarin wordt gewerkt. Het betreft hierbij zowel de mate van concurrentie in de markt, de mate van organisatorische ontwikkelingen en het takenpakket.
In Tabel 2.4 gaan we in op de cursusparticipatie van werkenden met verschillende arbeidscontracten. Uit kolom 1 maken we direct op dat er geen significant verschil is in de kans op het volgen van een cursus/ training tussen werknemers met een vast dienstverband en werknemers met een tijdelijk dienstverband met uitzicht op een vast contract. Dit is in lijn met eerdere studies (Borghans et al., 2014). Werknemers met een tijdelijk contract zonder uitzicht op een vast

contract én zelfstandigen hebben wel minder kans om in de twee jaar voorafgaand aan de enquête een cursus gevolgd te hebben (13\%, respectievelijk $16 \%$ ). Het meenemen van standaard controlevariabelen zorgt niet voor statistisch significante afnames in deze verschillen. Dit geldt ook voor het meenemen van verschillen in leefstijl en leefsituatie en voor het meenemen van persoonlijkheidskenmerken. Pas als we rekening houden met de inhoud van het werk verdwijnen de significante verschillen tussen werknemers met een tijdelijk contract zonder perspectief en zelfstandigen aan de ene kant en werknemers met een vast contract aan de andere kant. Vooral organisatorische ontwikkelingen, de mate van concurrentie waarin de organisatie opereert en een aantal taken blijken significant gerelateerd te zijn aan de cursusdeelname en verklaren daarmee het 
verschil tussen cursusdeelname van werknemers met een vast contract aan de ene kant versus cursusdeelname van werknemers met een tijdelijk contract zonder uitzicht op vast en zelfstandigen aan de andere kant.

\section{Verklaren van verschillen in informeel leren}

Tabel 2.5 laat zien in hoeverre het verschil in het percentage dat werkenden in verschillende leeftijdsgroepen kunnen leren van de taken die zij op hun werk uitvoeren, verklaard kan worden door persoons- of baankenmerken. We hanteren hierbij dezelfde aanpak als in de Tabellen $2.2-2.4$.

TABEL 2.5 Verschil in informeel leren op het werk naar leeftijd

\begin{tabular}{|l|c|c|c|c|c|c|}
\hline Informeel leren op het werk & $(1)$ & $(2)$ & $(3)$ & $(4)$ & $(5)$ & $(6)$ \\
\hline 16-39 jarigen & ref & ref & ref & ref & ref & ref \\
\hline $40-54$ jarigen & $-0,049^{* * *}$ & $-0,021$ & $-0,023$ & $-0,022$ & $-0,020$ & $-0,017$ \\
\hline $55-66$ jarigen & $-0,080^{* * *}$ & $-0,040^{* *}$ & $-0,038^{* *}$ & $-0,039^{* *}$ & $-0,038^{* *}$ & $-0,033^{*}$ \\
\hline Controle- variabelen & nee & ja & ja & ja & Ja & ja \\
\hline Leefstijl en leefsituatie & nee & nee & ja & ja & ja & ja \\
\hline Persoonlijkheid & nee & nee & nee & ja & ja & ja \\
\hline Inhoud werk & nee & nee & nee & nee & ja & ja \\
\hline HR-beleid & nee & nee & nee & nee & nee & ja \\
\hline
\end{tabular}

Bronnen: ROA LLL Enquête, 2017; NSS 2017; LISS, 2014-2017

In kolom 1 zien we terug dat vooral de 55-66 jarigen een veel kleiner deel van hun werktijd besteden aan taken waarvan zij kunnen leren dan de 16-39 jarigen. In mindere mate geldt dat ook voor de 40-54 jarigen. Het toevoegen van het opleidingsniveau, het aantal jaren dat men werkzaam is in de huidige functie of als zelfstandige en het soort dienstverband dat men heeft blijkt de leeftijdsverschillen in het informeel leren voor een groot deel te verklaren. Zodra deze factoren meegenomen worden blijkt dat het verschil tussen de 16-39 en 55-66 jarigen gehalveerd wordt. Daarnaast is er geen significant meer tussen het percentage informeel leren van de 16-39 en 40-54 jarigen (zie kolom 2). Echter, 55-66 jarigen blijken gemiddeld genomen nog steeds 4 procent minder werktijd te besteden aan taken waarvan zij kunnen leren dan 16-39 jarigen met eenzelfde aantal werkuren, opleidingsniveau en soort dienstverband. Het toevoegen van informatie over iemands leefstijl en leefsituatie, persoonlijkheid en de inhoud van de baan blijkt het verschil in het informeel leren op het werk tussen de jongste en oudste leeftijdscategorie niet verder te verkleinen. Zodra het HR-beleid meegenomen wordt, is het verschil in informeel leren tussen 16-39 jarigen en 55-66 jarigen nog slechts zwak significant. Dit lijkt met name te komen door het leerklimaat in de organisatie. 
Het verschil in informeel leren op het werk tussen laag- en hoogopgeleiden kan worden verklaard door het verschil in leeftijd, contractvorm, persoonlijkheid en door verschillen in de inhoud van het werk tussen deze groepen.

Tabel 2.6 laat zien in hoeverre het verschil in het percentage dat laag-, middelbaar en hoogopgeleide werkenden kunnen leren van de taken zij uitvoeren op het werk verklaard kan worden. Laagopgeleiden besteden bijna 10 procent minder tijd aan taken waarvan zij kunnen leren dan hoogopgeleiden. Dit wordt voor een deel verklaard doordat zij ouder zijn en minder vaak een vast contract hebben. Echter, ook nadat er voor deze factoren gecorrigeerd is, blijft er een significant verschil in informeel leren bestaan van 8 procent. Verschillen in persoonlijkheidskenmerken tussen laag- en hoogopgeleiden blijken ook verantwoordelijk voor het achterblijven van het informeel leren van de laagopgeleiden. Bevlogenheid, de bereidheid om risico te nemen en het openstaan voor nieuwe ervaringen zijn positief gerelateerd aan het percentage informeel leren en blijken een deel van het verschil in informeel leren tussen laagen hoogopgeleiden te verklaren. Na het meenemen van de verschillen in persoonlijkheid blijkt er nog 6,5 procent verschil in het informeel leren van laag- en hoogopgeleiden op het werk. Deze 6,5 procent worden wegverklaard door de inhoud van het werk (kolom 5). Met name de organisatorische en technologische ontwikkelingen als ook het belang van interpersoonlijke en taalvaardigheden zijn gerelateerd aan de mate van informeel leren van laag- versus hoogopgeleiden. Ook verdwijnt het significante verschil in de mate van informeel leren op het werk tussen middelbaar- en hoogopgeleiden zodra we rekening houden met de inhoud van het werk.

TABEL 2.6 Verschil in informeel leren naar opleidingsniveau

\begin{tabular}{|l|c|c|c|c|c|c|}
\hline Informeel leren op het werk & $(1)$ & $(2)$ & $(3)$ & $(4)$ & $(5)$ & (6) \\
\hline Laagopgeleiden & $-0,098^{* * *}$ & $-0,079^{* * *}$ & $-0,089^{* * *}$ & $-0,065^{* * *}$ & $-0,020$ & $-0,023$ \\
\hline Middelbaar opgeleiden & $-0,061^{* * *}$ & $-0,053^{* * *}$ & $-0,059^{* * *}$ & $-0,040^{* * *}$ & $-0,017$ & $-0,019$ \\
\hline Hoogopgeleiden & ref & ref & ref & ref & ref & ref \\
\hline Controle- variabelen & nee & ja & ja & ja & ja & ja \\
\hline Leefstijl en leefsituatie & nee & nee & ja & ja & ja & ja \\
\hline Persoonlijkheid & nee & nee & nee & ja & ja & ja \\
\hline Inhoud werk & nee & nee & nee & nee & ja & ja \\
\hline HR-beleid & nee & nee & nee & nee & nee & ja
\end{tabular}

Bronnen: ROA LLL Enquête, 2017; NSS 2017; LISS, 2014-2017

Verschillen in informeel leren op het werk tussen werknemers met een vast en tijdelijk dienstverband zijn slechts gedeeltelijk het gevolg van minder ervaring.
In Tabel 2.7 is eenzelfde exercitie gedaan voor het informeel leren naar contractvorm. Zoals al bleek uit paragraaf 1.1 leren werkenden met een tijdelijk contract en zelfstandigen juist 
meer van de taken op hun werk dan mensen met een vast dienstverband. Een eerste verklaring die hiervoor gegeven kan worden is dat dit komt omdat ze hun werk minder lang doen. Echter, dit blijkt slechts gedeeltelijk van invloed te zijn. Hoewel we een significante relatie vinden tussen het percentage informeel leren op het werk enerzijds en leeftijd en het aantal jaren werkervaring anderzijds, blijft het relatief hoge percentage informeel leren op het werk overeind voor werknemers met een tijdelijk contract zonder uitzicht op vast en voor zelfstandigen. Met andere woorden, de observatie dat werknemers met een tijdelijk contract zonder perspectief en zelfstandigen meer informeel leren op het werk is niet alleen te wijten aan hun jongere leeftijd en aan minder werkervaring. Een andere oorzaak wordt echter niet gevonden: leefstijl, leefsituatie, persoonlijkheid en bedrijfsfactoren blijken het verschil van 7 procent tussen werknemers met een vast contact en werknemers met een tijdelijk contract zonder perspectief niet te verklaren.

TABEL 2.7 Verschil in informeel leren naar contracttype

\begin{tabular}{|l|c|c|c|c|c|c|}
\hline Cursusdeelname & $(1)$ & $(2)$ & $(3)$ & $(4)$ & $(5)$ & (6) \\
\hline Vast contract & ref & ref & ref & ref & ref & ref \\
\hline Tijdelijk contract met perspectief & $0,093^{* * *}$ & $0,059^{* * *}$ & $0,057^{* * *}$ & $0,043^{* *}$ & $0,051^{* *}$ & $0,042^{* *}$ \\
\hline Tijdelijk contract zonder perspectief & 0,034 & 0,022 & 0,021 & 0,014 & 0,025 & 0,031 \\
\hline Zelfstandigen & $0,038^{*}$ & $0,048^{* *}$ & $0,053^{* * *}$ & 0,025 & $0,058^{* * *}$ & \\
\hline Controle- variabelen & nee & ja & ja & ja & ja & ja \\
\hline Leefstijl en leefsituatie & nee & nee & ja & ja & ja & ja \\
\hline Persoonlijkheid & nee & nee & nee & ja & ja & ja \\
\hline Inhoud werk & nee & nee & nee & nee & ja & ja \\
\hline HR-beleid & nee & nee & nee & nee & nee & ja
\end{tabular}

Bronnen: ROA LLL Enquête, 2017; LISS, 2015/2016

Het verschil in informeel leren tussen mensen met een vast dienstverband en mensen met een tijdelijk contract met perspectief neemt significant af als rekening gehouden wordt met het opleidingsniveau, de leeftijd en het aantal jaren dat men werkzaam is in de huidige functie. In plaats van een verschil van 9 procent blijft er echter nog steeds een verschil van 4 procent over, in het voordeel van de werknemer met een tijdelijk contract. Dit verschil blijkt niet te verklaren door het meenemen van variabelen die betrekking hebben op iemands leefstijl en leefsituatie, persoonlijkheid en de inhoud van het werk of het HR-beleid. 


\section{DETERMINANTEN VAN HET LEREN ONDER WERKENDEN MET EEN KWETSBARE POSITIE OP DE ARBEIDSMARKT}

In dit hoofdstuk geven wij inzicht in de factoren die van invloed zijn op het werkgerelateerd leergedrag van de werkenden met een kwetsbare positie op de arbeidsmarkt. Naast de standaard variabelen, geslacht, omvang en duur van het contract, leeftijd, opleidingsniveau en type contract, kijken we naar de invloed van vier clusters van determinanten: iemands persoonlijkheid, leefstijl en leefsituatie en de mate waarin iemand gestimuleerd wordt door het HR-beleid en de inhoud van het werk. We laten telkens per cluster variabelen zien in hoeverre deze de variantie in het werkgerelateerde leergedrag verklaren. Omdat de HR-instrumenten een grote relevantie hebben en door de organisatie zelf kunnen worden bijgesteld, kijken wij daarnaast ook naar de invloed van specifieke HR-instrumenten.

Paragraaf 3.1 gaat in op de determinanten van het werkgerelateerd leren van 55-66 jarige werkenden. Daarbij vergelijken we deze met de factoren die van invloed zijn op de jongere leeftijdsgroepen. Paragraaf 3.2 gaat in het op de determinanten van het werkgerelateerd leren van laagopgeleiden, in vergelijking met de middelbaar- en hoogopgeleiden. In paragraaf 2.3 staan de determinanten van het werkgerelateerde leren van zelfstandigen centraal. Deze worden vergeleken met die van werknemers. In paragraaf 3.4 richten we ons op de meest kwetsbare groep werknemers: degenen met een tijdelijk dienstverband zonder uitzicht op vast werk en vergelijken we deze met de werknemers met een tijdelijk dienstverband met uitzicht op vast werk en met werknemers die in vaste dienst zijn.

\subsection{5 tot 66 jarige werkenden}

In Tabel 3.1 is voor de 55 tot en met 66 jarigen aangegeven in hoeverre de clusters determinanten de geobserveerde variantie in het trainingsgedrag kunnen verklaren..$^{22}$ Uit de tabel blijkt dat de standaard controlevariabelen 4,7 procent van de variantie verklaren. Voor de jongere leeftijdsgroepen is de verklaarde variantie van dit cluster iets kleiner. Naast het opleidingsniveau en het type arbeidscontract blijkt ook de contractomvang een rol te spelen. Een 55-66 jarige die 10 uur meer werkt per week heeft 5 procent meer kans om een cursus te volgen.23 Terwijl iemands persoonlijkheid bij de 55-66 jarigen

22 Alle uitgevoerde analyses zijn Ordinary Least Squares (OLS) modellen.

23 Dit is niet uit Tabel 3.1 te halen. 
slechts 0,5 procent van de verschillen blijkt te verklaren, is dit percentage maar liefst gelijk aan 5,3 procent van de variantie voor 16 tot 39-jarigen. Leefstijl en leefsituatie blijken voor geen enkele leeftijdsgroep een verklarende rol te hebben. De inhoud van het werk blijkt wel belangrijk te zijn voor de trainingsdeelname. Als de organisatie waarin men werkzaam is aan organisatorische en/of technologische veranderingen onderhevig is, vergroot dit de kans op trainingsdeelname. Het takenpakket blijkt daarnaast ook van invloed op de trainingsparticipatie van werkenden. Zo blijkt dat 55-66 jarigen vaker participeren in een cursus als het beschikken over interpersoonlijke vaardigheden of taalvaardigheden belangrijk is voor hun werk.

TABEL 3.1 Verklaarde variantie cursusparticipatie naar groepen determinanten, naar leeftijd

\begin{tabular}{|l|r|r|r|}
\hline Variantie verklaard door: & 55 -66 jarigen & $16-39$ jarigen & $40-54$ jarigen \\
\hline Standaad controlevariabelen & $4,7 \%$ & $4,1 \%$ & $3,8 \%$ \\
\hline Persoonlijkheid & $0,5 \%$ & $5,3 \%$ & $2,8 \%$ \\
\hline Leefstijl en leefsituatie & $0 \%$ & $0 \%$ & $0 \%$ \\
\hline Inhoud werk & $7,8 \%$ & $9,6 \%$ & $8,3 \%$ \\
\hline HR-beleid & $3,5 \%$ & $6,4 \%$ & $9,3 \%$ \\
\hline Totale variantie verklaard & & & $12,1 \%$ \\
\hline N & $7,2 \%$ & $14,7 \%$ & 720 \\
\hline
\end{tabular}

Bronnen: ROA LLL Enquête, 2017; NSS, 2017; LISS, 2015/2016

Noot: verklaarde variantie is adjusted $R^{2}$.

Het HR-beleid heeft beduidend minder invloed op de trainingsparticipatie van 55-66 jarigen dan op de trainingsdeelname van werkenden van andere leeftijdsgroepen. Bij oudere werkenden zijn vooral taakroulatie en coaching gerelateerd aan cursusdeelname. deze gerelateerd zijn aan de trainingsdeelname. De tabel laat zien dat de meeste HR-instrumenten geen significante invloed hebben op iemands cursusparticipatie. Dit geldt voor alle leeftijdsgroepen. Opvallend genoeg blijken HR-instrumenten voor de verschillende leeftijdsgroepen een andere rol te spelen. De cursusparticipatie van 55-66 jarigen blijkt positief samen te hangen met taakroulatie en zwak significant met coaching. Voor de 16-54 jarigen geldt daarentegen dat een persoonlijk opleidings- of ontwikkelplan significant positief gerelateerd is aan cursusparticipatie. De omvang van deze correlatie is ongeveer gelijk aan die tussen coaching en cursusparticipatie bij de 55-66 jarigen. Voor 40-54 jarigen blijkt het beschikken over een persoonlijk ontwikkelingsplan ook positief samen te hangen met cursusparticipatie. Daarnaast participeren zij significant vaker als zij functionerings- en beoordelingsgesprekken hebben en als zij regelmatige feedback van collega's ontvangen. 
Als alle determinanten worden meegenomen kunnen we 7,2 procent van de totale variantie in de cursusparticipatie van 55-66 jarigen verklaren. Dit is veel minder dan bij de andere leeftijdsgroepen. Dit impliceert dat we belangrijke factoren missen die bepalen waarom een 55-66 jarige werkende al dan niet een werkgerelateerde training volgt. Toch is de verklaringskracht van het model vergelijkbaar met die uit andere studies die de cursusparticipatie van groepen werkenden proberen te verklaren. ${ }^{24}$

TABEL 3.2 Betekenis van specifieke HR-instrumenten voor de cursusparticipatie, naar leeftijd

\begin{tabular}{|l|c|c|c|}
\hline & $(1)$ & $(2)$ & $(3)$ \\
\hline Afh. Var.: cursusparticipatie & $55-66$ jarigen & $16-39$ jarigen & $40-54$ jarigen \\
\hline Functionerings- en/of beoordelingsgesprekken & 0,0897 & 0,0840 & $0,118^{* *}$ \\
\hline Persoonlijk opleidings- of ontwikkelplan & 0,0113 & $0,102^{* *}$ & $0,145^{* * *}$ \\
\hline Regelmatige feedback van leidinggevende & $-0,0361$ & $-0,0220$ & $-0,0253$ \\
\hline Regelmatige feedback door collega's & 0,0696 & $-0,0421$ & $0,104^{* *}$ \\
\hline Loopbaanplan & $-0,119$ & 0,0643 & 0,0319 \\
\hline Coaching & $0,107^{*}$ & 0,0169 & $-0,0393$ \\
\hline Functierotatie & 0,0135 & $-0,0937$ & $-0,0928$ \\
\hline Taakroulatie & $0,152^{* *}$ & 0,0633 & 0,0623 \\
\hline Detachering binnen dezelfde organisatie & $-0,0551$ & 0,0451 & $-0,00702$ \\
\hline Prestatiebeloning of bonussen & $-0,0561$ & $-0,0193$ & $-0,0141$ \\
\hline & & & 720 \\
\hline N & 547 & 526 & $12,1 \%$ \\
\hline Totale variantie verklaard & $7,2 \%$ & $14,7 \%$ & 7 \\
\hline
\end{tabular}

*** $\mathrm{p}<0.01,{ }^{* *} \mathrm{p}<0.05,{ }^{*} \mathrm{p}<0.1$

Bronnen: ROA LLL Enquête, 2017; NSS, 2017; LISS, 2014-2017

Noot: coëfficiënten gebaseerd op regressiemodel waar alle clusters variabelen tegelijk zijn opgenomen.

Tabel 3.3 laat zien in hoeverre het informeel leren op het werk verklaard kan worden door de verschillende clusters variabelen. Voor de 55-66 jarigen kan 10,1 procent van de variantie in het informeel leren op het werk verklaard worden door alle variabelen tezamen. 5 procent wordt verklaard door de standaard controlevariabelen. Vooral het opleidingsniveau en het type contract blijken hiervoor verantwoordelijk. Zowel hoogopgeleiden als werkenden met een tijdelijk dienstverband met uitzicht op vast, als ook zelfstandigen, besteden een groter percentage van hun werktijd aan taken waarvan zij leren. De verklarende waarde van deze kenmerken blijkt groter bij de 55-66 jarigen dan bij de 16-39 jarigen. Voor de jongeren en de 40-54 jarigen zijn het opleidingsniveau en de anciënniteit bepalend. Hoe langer men werkzaam is binnen de huidige functie, hoe

24 Georgellis \& Lange (2007) vinden een Pseudo R ${ }^{2}$ van 0,19; Nelen \& De Grip (2009) 0,18 voor deeltijders en 0,10 voor voltijders. Als wij, net als bovenstaande studies een probit model zouden schatten, komen wij op een Pseudo $\mathrm{R}^{2}$ van respectievelijk 12,8\%, 19,8\% en $15 \%$ voor de leeftijdscategorieën 55-66, 16-39 en 40-54 jarigen. 
lager het percentage van de werktijd waarin men informeel leert. Deze negatieve relatie wordt voor de 55-66 jarigen dus niet gevonden.

TABEL 3.3 Verklaarde variantie informeel leren op het werk naar clusters determinanten, naar leeftijd

\begin{tabular}{|l|r|r|r|}
\hline Variantie verklaard door: & $55-66$ jarigen & $16-39$ jarigen & $40-54$ jarigen \\
\hline Standaad controlevariabelen & $5 \%$ & $2,4 \%$ & $2,4 \%$ \\
\hline Persoonlijkheid & $5,1 \%$ & $10,3 \%$ & $3 \%$ \\
\hline Leefstijl en leefsituatie & $0 \%$ & $0 \%$ & $0 \%$ \\
\hline Inhoud werk & $5,5 \%$ & $7,1 \%$ & $4,3 \%$ \\
\hline HR-beleid & $3,3 \%$ & $6,3 \%$ & $4,4 \%$ \\
\hline Totale variantie verklaard & & & $8,7 \%$ \\
\hline N & $10,1 \%$ & $16,4 \%$ & 720 \\
\hline
\end{tabular}

Bronnen: ROA LLL Enquête, 2017; NSS, 2017; LISS, 2014-2017

Noot: verklaarde variantie is adjusted $R^{2}$.

Technologische ontwikkelingen zijn positief gerelateerd aan de mate van informeel leren onder alle leeftijdsgroepen.
De persoonlijkheidsvariabelen verklaren ook ongeveer 5 procent van de variantie in het informeel leren op het werk onder 55-66 jarigen. 55-66 jarigen die bevlogen zijn,

bereid zijn om risico te nemen of een open houding hebben ten opzichte van nieuwe ervaringen leren op hun werk het meest. De effecten voor openheid en bevlogenheid worden ook gevonden voor de andere leeftijdsgroepen. Bij de groep 40-54 jarigen, blijkt daarnaast positieve reciprociteit negatief samen te hangen met informeel leren terwijl bij de groep 16-39 besluiteloosheid positief samenhangt met informeel leren. ${ }^{25}$ Leefstijl en leefsituatie blijken niet alleen bij het formele maar ook bij het informele leren op het werk geen verklarende rol te spelen. Net als bij de cursusparticipatie speelt de inhoud van het werk wel een rol bij het informeel leren op het werk. Technologische ontwikkelingen blijken positief gerelateerd te zijn aan de mate van informeel leren op het werk onder alle leeftijdsgroepen. Voor 16-39 jarigen zijn organisatorische veranderingen daarnaast ook positief gerelateerd aan de mate van informeel leren op het werk, terwijl deze relatie juist negatief, maar zwak significant is voor 55-66 jarigen en niet-significant voor 40-54 jarigen. Het takenpakket blijkt voor wat betreft het informele leren een rol te spelen. Zo blijkt de mate van informeel leren op het werk onder 55-66 jarigen positief samen te hangen met het belang van interpersoonlijke vaardigheden op het werk terwijl het belang van kennis van de organisatie negatief samenhangt met het informeel leren voor deze groep. Voor 16-39 jarigen blijkt het belang van taalvaardigheden positief samen te hangen met informeel leren, terwijl voor 40-54 jarigen interpersoonlijke vaardigheden en het belang van probleemoplossend vermogen positief samenhangen met de mate van informeel leren op het werk.

25 Hoewel bij de 40-54 jarigen meer persoonlijkheidskenmerken gerelateerd zijn aan het informeel leren op het werk dan voor de 16-39 jarigen, is de verklaarde variantie lager. 
TABEL 3.4 Betekenis van specifieke HR-instrumenten voor het informeel leren op het werk, naar leeftijd

\begin{tabular}{|c|c|c|c|}
\hline & (1) & (2) & (3) \\
\hline Afh. Var.: Informeel leren & 55-66 jarigen & 16-39 jarigen & 40-54 jarigen \\
\hline Functionerings- en/of beoordelingsgesprekken & $-4,413$ & 2,048 & $4,619^{*}$ \\
\hline Persoonlijk opleidings- of ontwikkelplan & 3,740 & $-3,105$ & $-0,399$ \\
\hline Regelmatige feedback van leidinggevende & 3,028 & $-0,194$ & $-5,836^{* *}$ \\
\hline Regelmatige feedback door collega's & 0,730 & 1,836 & 2,776 \\
\hline Loopbaanplan & $-2,794$ & 3,969 & 3,023 \\
\hline Coaching & $-1,743$ & $-1,040$ & 2,273 \\
\hline Functierotatie & 5,704 & $-1,957$ & $-1,035$ \\
\hline Taakroulatie & $-5,346^{*}$ & 0,803 & $6,296^{* *}$ \\
\hline Detachering binnen dezelfde organisatie & 4,652 & 1.562 & $-1,265$ \\
\hline Prestatiebeloning of bonussen & $5,879^{* *}$ & $-0,873$ & $-2,884$ \\
\hline N & 547 & 526 & 720 \\
\hline Totale variantie verklaard & $10,1 \%$ & $16,4 \%$ & $8,7 \%$ \\
\hline
\end{tabular}

*** $\mathrm{p}<0.01,{ }^{* *} \mathrm{p}<0.05,{ }^{*} \mathrm{p}<0.1$

Bronnen: ROA LLL Enquête, 2017; NSS, 2017 ; LISS, 2015/2016

Noot: coëfficiënten gebaseerd op regressiemodel waar alle clusters variabelen tegelijk zijn opgenomen.

Het gevoerde HR-beleid verklaart iets meer dan 3 procent van de variantie in het informeel leren op het werk onder 55-66 jarigen. In Tabel 3.4 wordt aangegeven om welke HR-instrumenten het precies gaat. Zo blijken 55-66 jarigen in organisaties waar sprake is van prestatiebeloningen of bonussen vaker informeel te leren op het werk. Taakroulatie hangt voor deze groep echter negatief samen met de mate van informeel leren op het werk, al is dit effect alleen zwak significant. Interessant genoeg zijn er geen significante relaties tussen specifieke HR-instrumenten en de mate van informeel leren op het werk door 16-39 jarigen. Dit lijkt in contrast te staan met de bevinding in Tabel 3.3 waaruit blijkt dat ruim 6 procent van de variantie in informeel leren op het werk door HR-beleid verklaard wordt. Het leerklimaat in de organisatie, waarvoor we een sterk positief verband met informeel leren vinden, is hier echter in het geheel verantwoordelijk voor. Het leerklimaat van de organisatie speelt geen rol bij het verklaren van de mate van informeel leren binnen de overige leeftijdscategorieën. Bij werkenden tussen de 40 en 55 jaar oud blijken regelmatige feedback van door de leidinggevende en taakroulatie sterk samen te hangen met de mate van informeel leren op het werk. In het eerste geval is de relatie negatief en in het tweede geval positief. Daarnaast blijken functioneringsen/of beoordelingsgesprekken voor deze groep werkenden zwak positief samen te hangen met informeel leren. 


\subsection{Laagopgeleiden}

Laagopgeleiden met een tijdelijk contract zonder uitzicht op vast hebben een kwart minder kans om een cursus te volgen. Onder laagopgeleide vrouwen is de kans op cursus $14 \%$ lager dan bij mannen.
In Tabel 3.5 wordt per cluster variabelen aangegeven in hoeverre de variantie in de cursusparticipatie door laagopgeleiden verklaard kan worden. De standaard controle-variabelen verklaren 2,9 procent van de variatie. Het hebben van een tijdelijk contract zonder uitzicht op vast verkleint de

kans op cursusdeelname onder laagopgeleiden met 30 procent. Ook hebben laagopgeleide vrouwen 14 procent minder kans op deelname aan een cursus dan laagopgeleide mannen. De werkuren en de duur van het dienstverband blijken niet van belang. De rol van standaard controlevariabelen in het verklaren van cursusparticipatie is hoger onder laagopgeleiden dan onder middelbaar opgeleiden en hoogopgeleiden.

Persoonlijkheidskenmerken blijken belangrijker in het verklaren van de trainingsparticipatie van laagopgeleiden dan in het verklaren van de trainingsparticipatie van middelbaar en hoogopgeleiden. Onder laagopgeleiden blijken bevlogenheid, de bereidheid om risico te nemen en vertrouwen positief gerelateerd te zijn aan cursusparticipatie, terwijl er voor middelbaar opgeleiden een zwak positief verband is met bevlogenheid en toekomstgerichtheid (tijdsvoorkeur). Bevlogenheid hangt ook positief samen met de cursusparticipatie van hoogopgeleiden, terwijl de bereidheid om risico te nemen voor deze groep negatief samenhangt met cursusparticipatie. Dat laatste geldt ook voor de mate van toekomstgerichtheid, al is die correlatie enkel zwak significant.

TABEL 3.5 Verklaarde variantie in cursusparticipatie naar groepen determinanten, naar opleidingsniveau

\begin{tabular}{|l|r|r|r|}
\hline Variantie verklaard door: & Laag opgeleiden & Middelbaar opgeleiden & Hoog opgeleiden \\
\hline Standaad controlevariabelen & $2,9 \%$ & $1,3 \%$ & $0,5 \%$ \\
\hline Persoonlijkheid & $4,3 \%$ & $1,6 \%$ & $1,8 \%$ \\
\hline Leefstijl en leefsituatie & $0 \%$ & $0 \%$ & $0 \%$ \\
\hline Inhoud werk & $11,6 \%$ & $5 \%$ & $5,1 \%$ \\
\hline HR-beleid & $13,1 \%$ & $5,4 \%$ & $3,5 \%$ \\
\hline Totale variantie verklaard & & & \\
\hline N & $14,5 \%$ & $6,6 \%$ & $6,5 \%$ \\
\hline
\end{tabular}

Bronnen: ROA LLL Enquête, 2017; NSS, 2017; LISS, 2014-2017

Noot: verklaarde variantie is adjusted $R^{2}$. 
De inhoud van het werk is medebepalend voor de cursusparticipatie van laagopgeleiden.
Wederom blijkt iemands leefstijl en leefsituatie geen invloed te hebben op de cursusparticipatie. Dit geldt niet alleen voor de laagopgeleiden, maar ook voor werkenden met een middelbare of hogere opleiding. De inhoud van het werk is daarentegen wel van belang voor de cursusparticipatie van laagopgeleiden. 11,6 procent van de variatie in cursusparticipatie wordt verklaard door dit cluster. Het gaat dan met name om de mate waarin technologische ontwikkelingen een rol spelen in het bedrijf. Ook zien we dat de mate waarin interpersoonlijke vaardigheden en taalvaardigheden belangrijk zijn in het werk positief samenhangen met cursusparticipatie. Het belang van het gebruik van computers hangt zwak negatief samen met cursusparticipatie voor laagopgeleiden.

Het HR-beleid is erg bepalend voor de trainingsdeelname van laagopgeleiden. Met name de feedback van collega's en het hebben van een opleidings- of ontwikkelplan spelen een positieve rol.
De rol van het HR-beleid in het verklaren van trainingsgedrag onder laagopgeleiden is erg groot. Ruim 13 procent van alle waargenomen variatie in trainingsgedrag onder deze groep kan verklaard worden door het HR-beleid. Uit Tabel 3.6 maken we op dat de

cursusparticipatie van laagopgeleiden positief gerelateerd is aan bepaalde HR-instrumenten. Een persoonlijk opleidings- of ontwikkelplan en regelmatige feedback van collega's vergroten de trainingsdeelname. ${ }^{26}$ Wel blijkt er opmerkelijk genoeg een negatieve relatie te zijn tussen het ontvangen van feedback van de leidinggevende en cursusparticipatie voor laagopgeleiden. Een mogelijke verklaring hiervoor is dat deze vorm van feedback vaker onderdeel uitmaakt van beoordelingen door de leidinggevende en wellicht vaker gepercipieerd wordt als demotiverend. Nader onderzoek is nodig om hier uitsluitsel over te geven. Voor middelbaar opgeleiden is er alleen een zwak positieve relatie met regelmatige feedback van collega's, terwijl er voor hoogopgeleiden een zwak positieve relatie met het hebben van functionerings- en beoordelingsgesprekken en het beschikken over een persoonlijk opleidings- en ontwikkelingsplan is. Daarnaast blijkt taakroulatie een HR-instrument te zijn dat voor deze groep werkenden positief samenhangt met de cursusparticipatie.

26 Dit bevestigt dat het trainingsverschil in opleidingsniveau voor ongeveer $37 \%$ verklaard wordt doordat laagopgeleiden minder vaak een POP hebben en minder regelmatige feedback krijgen van hun collega's, in plaats van dat een POP en feedback van collega's minder effectief zijn voor laagopgeleiden vergeleken met middelbaar- en hoogopgeleiden. 
TABEL 3.6 Betekenis van specifieke HR-instrumenten voor de cursusparticipatie, naar opleidingsniveau

\begin{tabular}{|l|c|c|c|}
\hline Afh. Var.: Cursusparticipatie & $(1)$ & $(2)$ & $(3)$ \\
\hline Functionerings- en/of beoordelingsgesprekken & Laag & Middelbaar & Hoog \\
\hline Persoonlijk opleidings- of ontwikkelplan & 0,120 & 0,0615 & $0,108^{*}$ \\
\hline Regelmatige feedback van leidinggevende & $0,149^{* *}$ & 0,0758 & $0,0763^{*}$ \\
\hline Regelmatige feedback door collega's & $-0,176^{* *}$ & $-0,0490$ & 0,00597 \\
\hline Loopbaanplan & $0,220^{* * *}$ & $0,0878^{*}$ & $-0,00649$ \\
\hline Coaching & $-0,0907$ & $-0,0507$ & 0,0206 \\
\hline Functierotatie & 0,0460 & 0,0657 & 0,00296 \\
\hline Taakroulatie & $-0,115$ & $-0,100$ & $-0,0161$ \\
\hline Detachering binnen dezelfde organisatie & 0,0943 & 0,0494 & $0,119^{* *}$ \\
\hline Prestatiebeloning of bonussen & $-0,0498$ & 0,0882 & $-0,0342$ \\
\hline N & $-0,0612$ & $-0,0371$ & 0,0261 \\
\hline Totale variantie verklaard & & & 789 \\
\hline
\end{tabular}

*** $p<0.01,{ }^{* *} p<0.05,{ }^{*} p<0.1$.

Bronnen: ROA LLL Enquête, 2017; NSS, 2017; LISS, 2014-2017

Noot: coëfficiënten gebaseerd op regressiemodel waar alle clusters variabelen tegelijk zijn opgenomen.

Zowel het HR-beleid, als de inhoud van het werk, blijken een grotere rol te spelen in het verklaren van cursusparticipatie van laagopgeleiden dan in het verklaren van cursusparticipatie van middelbaar- en hoogopgeleiden.

Laagopgeleide vrouwen leren ruim $6,5 \%$ minder op het werk dan laagopgeleide mannen. Dit is voornamelijk toe te schrijven aan het feit dat laagopgeleide vrouwen vaker in bedrijven werken waar sprake is van weinig technologische veranderingen.
Tabel 3.7 geeft aan in hoeverre de door ons onderscheiden clusters van variabelen de variantie in het informeel leren op het werk kunnen verklaren. Voor de laagopgeleiden is dit 11 procent. 2,7 procent wordt verklaard door de standaard controlevariabelen. Zo blijkt dat onder de laagopgeleide werkenden diegenen met een tijdelijk contract met uitzicht op een vast contract het meeste informeel leren op het werk. ${ }^{27}$ Laagopgeleide vrouwen leren daarentegen 5,6 procent minder op het werk dan laagopgeleide mannen (met een vergelijkbare leeftijd, contractvorm, omvang en duur van het dienstverband). De controlevariabelen die het informeel leren onder middelbaar opgeleiden verklaren, blijken opmerkelijk genoeg andere te zijn: de leeftijd en de duur van het arbeidscontract. Hoe ouder iemand is en hoe langer hij of zij werkzaam is in de huidige functie, hoe lager het percentage informeel leren op het werk.

27 Onder middelbaar opgeleiden leren de zelfstandigen informeel het meeste en onder hoogopgeleiden de tijdelijke werknemers zonder perspectief op een vaste aanstelling. 
TABEL 3.7 Verklaarde variantie informeel leren op het werk naar groepen determinanten, naar leeftijd

\begin{tabular}{|l|r|r|r|}
\hline Variantie verklaard door: & Laag-opgeleiden & Middelbaar opgeleiden & Hoog-opgeleiden \\
\hline Standaad controlevariabelen & $2,7 \%$ & $3,2 \%$ & $2,1 \%$ \\
\hline Persoonlijkheid & $1,7 \%$ & $4,7 \%$ & $6,3 \%$ \\
\hline Leefstijl en leefsituatie & $2,2 \%$ & $0,6 \%$ & $0,2 \%$ \\
\hline Inhoud werk & $7,2 \%$ & $5,1 \%$ & $0,8 \%$ \\
\hline HR-beleid & $4,2 \%$ & $3,3 \%$ & $3,2 \%$ \\
\hline Totale variantie verklaard & & & $9,6 \%$ \\
\hline N & $11 \%$ & $11,3 \%$ & 789 \\
\hline
\end{tabular}

Bronnen: ROA LLL Enquête, 2017; NSS, 2017; LISS, 2014-2017

Noot: verklaarde variantie is adjusted $R^{2}$.

Laagopgeleiden met examenvrees blijken over het algemeen iets meer informeel te leren op het werk. Andere persoonlijkheidskenmerken hebben geen invloed op de mate waarin laagopgeleiden informeel leren. Dit in tegenstelling tot werkenden met een middelbare of hoge opleidingsachtergrond. Zowel middelbaar opgeleiden als hoogopgeleiden die openstaan voor nieuwe ervaringen en bevlogen zijn, leren meer informeel op het werk. Daarnaast is de mate waarin middelbaar opgeleiden bereid zijn risico te nemen positief gerelateerd aan de mate van informeel leren op het werk. Bij hoogopgeleiden blijkt de mate van besluiteloosheid zwak positief samen te hangen met het informeel leren op het werk.

Leefstijl en leefsituatie blijken nauwelijks gerelateerd te zijn aan de mate waarin iemand informeel leert op het werk.

Het informeel leren op het werk van laagopgeleiden wordt voornamelijk bepaald door de inhoud van het werk (met name als gevolg van technologische veranderingen) en het HR-beleid. (positieve relatie met informeel leren op het werk) en (2) de mate van concurrentie in de markt waarin de organisatie opereert (negatieve relatie met informeel leren op het werk). Daarnaast blijkt het belang van taalvaardigheid op het werk positief samen te hangen met de mate van informeel leren onder laagopgeleiden. Voor middelbaar opgeleiden vinden we net als bij de laagopgeleiden een positieve relatie met technologische verandering. Daarnaast vinden we voor deze groep werkenden een positieve relatie tussen het belang van interpersoonlijke vaardigheden op het werk en de mate waarin er informeel geleerd wordt en een negatieve relatie tussen de mate waarin er informeel wordt geleerd op het werk en de stabiliteit van de marktvraag. Onder hoogopgeleiden is geen enkele variabele met betrekking tot de inhoud van het werk of het takenpakket gerelateerd aan het informeel leren op het werk. 
Het hebben van een persoonlijk opleidings- of ontwikkelplan is niet alleen gerelateerd aan de cursusparticipatie van laagopgeleiden maar ook aan de mate waarin zij informeel leren op hun werk.

Met betrekking tot het HR-beleid blijkt er voor middelbaar en hoogopgeleiden een grotere rol te zijn voor het leerklimaat dan voor laagopgeleiden. ${ }^{28}$ Voor laagopgeleiden blijkt daarentegen met name het hebben van een persoonlijk opleidingsof ontwikkelplan gerelateerd te zijn aan de mate van informeel leren (zie Tabel 3.8). Voor middelbaar opgeleiden vinden we alleen een zwak significant negatief verband tussen prestatiebeloningen of bonussen en informeel leren, terwijl we hier onder hoogopgeleiden een zwak positief verband vinden. Daarnaast vinden we voor deze groep een zwak positief verband met regelmatige feedback van collega's.

TABEL 3.8 Betekenis van specifieke HR-instrumenten voor het informeel leren op het werk, naar opleidingsniveau

\begin{tabular}{|l|c|c|c|}
\hline & $(1)$ & $(2)$ & $(3)$ \\
\hline Afh. Var.: Informeel leren & Laag & Middelbaar & Hoog \\
\hline Functionerings- en/of beoordelingsgesprekken & & & 1,274 \\
\hline Persoonlijk opleidings- of ontwikkelplan & $-2,577$ & 2,130 & $-0,272$ \\
\hline Regelmatige feedback van leidinggevende & $7,843^{* *}$ & $-1,762$ & $-0,324$ \\
\hline Regelmatige feedback door collega's & $-1,806$ & $-3,446$ & $4,005^{*}$ \\
\hline Loopbaanplan & 3,568 & $-0,962$ & 1,205 \\
\hline Coaching & 1,214 & 1,723 & $-1,714$ \\
\hline Functierotatie & 0,398 & 2,868 & $-3,866$ \\
\hline Taakroulatie & 3,750 & 4,564 & 1,001 \\
\hline Detachering binnen dezelfde organisatie & $-1,181$ & 3,188 & 0,327 \\
\hline Prestatiebeloning of bonussen & 4,566 & 0,167 & $3,692^{*}$ \\
\hline & $-4,834$ & $-4,559^{*}$ & \\
\hline N & & & 789 \\
\hline Totale variantie verklaard & 324 & 680 & $9,6 \%$ \\
\hline
\end{tabular}

*** $\mathrm{p}<0.01,{ }^{* *} \mathrm{p}<0.05,{ }^{*} \mathrm{p}<0.1$

Bronnen: ROA LLL Enquête, 2017; NSS, 2017; LISS, 2014-2017

Noot: coëfficiënten gebaseerd op regressiemodel waar alle clusters variabelen tegelijk zijn opgenomen.

\subsection{Zelfstandigen}

In deze paragraaf vergelijken we de determinanten van het leergedrag van zelfstandigen met het leergedrag van werknemers. Uit Tabel 3.9 wordt allereerst duidelijk dat alle variabelen samen een ongeveer even grote verklarende rol spelen voor de cursusparticipatie

28 Bij middelbaar opgeleiden verdwijnt de rol van het leerklimaat als de andere variabelen in de analyse meegenomen worden. 
van zelfstandigen als bij de werknemers. Dit is verrassend omdat de cursusparticipatie van werknemers voor een relatief groot deel verklaard wordt door het HR-beleid van de organisatie waar men werkzaam is. ${ }^{29}$ Voor de zelfstandigen is er logischerwijs geen informatie over het gevoerde HR-beleid.

TABEL 3.9 Verklaarde variantie cursusparticipatie naar groepen determinanten, voor zelfstandigen en werknemers

\begin{tabular}{|l|r|r|}
\hline Variantie verklaard door: & Zelfstandigen & Werknemers \\
\hline Standaad controlevariabelen & $7,8 \%$ & $3,7 \%$ \\
\hline Persoonlijkheid & $2,2 \%$ & 3,5 \\
\hline Leefstijl en leefsituatie & $0 \%$ & $0 \%$ \\
\hline Inhoud werk & $5,3 \%$ & $8,6 \%$ \\
\hline HR-beleid & - & $6,9 \%$ \\
\hline Totale variantie verklaard & $11,5 \%$ & $12,4 \%$ \\
\hline N & 152 & 1.663
\end{tabular}

Bronnen: ROA LLL Enquête, 2017; NSS, 2017; LISS, 2014-2017

Noot: verklaarde variantie is adjusted $\mathrm{R}^{2}$.

Cursusparticipatie onder zelfstandigen is positief gerelateerd aan zowel opleidingsniveau als leeftijd
De variantie die verklaard wordt door het meenemen van de standaard controlevariabelen is groter voor de zelfstandigen dan voor de werknemers. Bij de werknemers zijn

het opleidingsniveau en het aantal uren dat men werkt positief gerelateerd aan hun cursusparticipatie. Voor zelfstandigen is er een positief verband met opleidingsniveau en leeftijd.

lemands persoonlijkheid blijkt bepalender voor de cursusparticipatie van werknemers dan voor zelfstandigen. Voor zelfstandigen is er een positieve samenhang tussen openheid voor nieuwe ervaringen en cursusparticipatie. Ook vinden we zwak positieve verbanden met bevlogenheid en vertrouwen. Voor werknemers vinden we positieve verbanden tussen cursusparticipatie enerzijds en besluiteloosheid, bevlogenheid, de bereidheid om risico te nemen en openheid voor nieuwe ervaringen anderzijds. Tevens vinden we een zwak negatieve relatie tussen positieve reciprociteit en cursusparticipatie voor werknemers. Leefstijl en leefsituatie hebben zowel voor zelfstandigen als voor werknemers geen invloed op de cursusparticipatie. De inhoud van het werk hangt niet samen met de cursusparticipatie van zelfstandigen, maar wel met de cursusparticipatie van werknemers. Voor werknemers geldt dat een hogere mate van technologische verandering gepaard gaat met een hogere cursusparticipatie. Qua takenpakket geldt dat zelfstandigen die veel gebruik maken van probleemoplossend vermogen vaker een cursus volgen. Hetzelfde geldt ook voor werknemers die werkzaam zijn in banen waar

$29 \mathrm{Er}$ is ook geen sprake van minder variatie in de cursusparticipatie van zelfstandigen (gemiddelde is $43 \%$, standaard deviatie is 0.50) dan van werknemers (gemiddelde is $56 \%$, standaard deviatie is 0.50 ). 
interpersoonlijke vaardigheden, taalvaardigheden en kennis van de organisatie belangrijk zijn.

Onder zelfstandigen blijken persoonlijkheidskenmerken voor een relatief groot deel bepalend voor de mate van informeel leren op het werk.
Tabel 3.10 laat zien dat de verschillen in de mate van informeel leren op het werk bij werknemers iets beter verklaard kunnen worden door de verschillende clusters van potentiële determinanten. De standaard controlevariabelen zijn niet in staat een deel van de variantie in de mate van informeel leren op het werk te verklaren voor zelfstandigen. Alleen het opleidingsniveau blijkt van belang, waarbij een hoger opleidingsniveau samenhangt met een hogere mate van informeel leren. Bij de werknemers spelen ook de leeftijd en de duur van het dienstverband een rol. Hoe ouder en hoe langer iemand werkzaam is in de huidige functie, hoe minder er informeel geleerd wordt op het werk. Bij zowel zelfstandigen als werknemers blijken de verschillende aspecten van iemands persoonlijkheid wel een rol te spelen voor de mate waarin er op het werk informeel wordt geleerd: Open staan voor nieuwe ervaringen, bevlogenheid en vertrouwen zijn positief gerelateerd aan de mate van informeel leren op het werk onder zelfstandigen. ${ }^{30}$ Bij werknemers vinden we geen effect van vertrouwen, maar wel een relatie tussen besluiteloosheid (positief), positieve reciprociteit (zwak negatief) en de bereidheid om risico te nemen (positief) in combinatie met de mate waarin men informeel leert. De mate waarin technologische ontwikkelingen de inhoud van het werk veranderen is enkel significant positief gerelateerd aan het informeel leren op het werk van werknemers. Zelfstandigen leren wel meer informeel op het werk als probleemoplossend vermogen een belangrijk onderdeel is van hun werk. Werknemers waarvoor interpersoonlijke vaardigheden en taalvaardigheden belangrijk zijn op het werk leren ook relatief veel van hun werk, terwijl werknemers waarvoor kennis van de organisatie belangrijk is juist in minder mate informeel leren op het werk.

TABEL 3.10 Verklaarde variantie informeel leren op het werk naar groepen determinanten, voor zelfstandigen en werknemers

\begin{tabular}{|l|r|r|}
\hline Variantie verklaard door: & Zelfstandigen & Werknemers \\
\hline Standaad controlevariabelen & $0 \%$ & $5,2 \%$ \\
\hline Persoonlijkheid & $5,5 \%$ & $5,8 \%$ \\
\hline Leefstijl en leefsituatie & $1,6 \%$ & $0 \%$ \\
\hline Inhoud werk & $5 \%$ & $6,3 \%$ \\
\hline HR-beleid & - & $4,3 \%$ \\
\hline Totale variantie verklaard & & $12,3 \%$ \\
\hline N & 9,9 & 1.663 \\
\hline
\end{tabular}

Bronnen: ROA LLL Enquête, 2017; NSS, 2017; LISS, 2014-2017

Noot: verklaarde variantie is adjusted $\mathrm{R}^{2}$.

30 In het geval van bevlogenheid en vertrouwen is het verband zwak significant. 


\subsection{Werknemers met een tijdelijk contract zonder uitzicht op vast}

De inhoud van het werk is voor werknemers met een tijdelijk contract zonder uitzicht op vast minder sterk gerelateerd aan de cursusparticipatie dan bij vaste medewerkers en bij tijdelijke medewerkers met uitzicht op een vast contract.
In deze paragraaf vergelijken we de determinanten van het leergedrag van werknemers met een tijdelijk contract zonder uitzicht op vast werk met het leergedrag van andere werknemers. ${ }^{31}$ Vanwege het relatief lage aantal tijdelijke werknemers zonder uitzicht op een vaste aanstelling bespreken we de

clusters niet in detail..$^{32}$

TABEL 3.11 Verklaarde variantie cursusparticipatie naar groepen determinanten, naar contractvorm

\begin{tabular}{|l|r|r|r|}
\hline Variantie verklaard door: & $\begin{array}{r}\text { Tijdelijk contract zonder } \\
\text { perspectief }\end{array}$ & $\begin{array}{r}\text { Tijdelijk contract met } \\
\text { perspectief }\end{array}$ & Vast contract \\
\hline Standaad controlevariabelen & $4,1 \%$ & $1,9 \%$ & $3,4 \%$ \\
\hline Persoonlijkheid & $8,1 \%$ & $1,5 \%$ & $2,9 \%$ \\
\hline Leefstijl en leefsituatie & $3,2 \%$ & $0 \%$ & $0 \%$ \\
\hline Inhoud werk & $1,2 \%$ & $4,9 \%$ & $8,2 \%$ \\
\hline HR-beleid & $7,2 \%$ & $3,3 \%$ & $6 \%$ \\
\hline & & & $11,3 \%$ \\
\hline Totale variantie verklaard & $5,5 \%$ & $9 \%$ & 1.418 \\
\hline N
\end{tabular}

Bronnen: ROA LLL Enquête, 2017; NSS, 2017; LISS, 2014-2017

Noot: verklaarde variantie is adjusted $R^{2}$.

De groep vaste werknemers is het grootst. Voor hen is zowel het opleidingsniveau als het aantal uren dat men per week werkt bepalend voor de cursusparticipatie. Bevlogenheid, open staan voor nieuwe ervaringen en vertrouwen zijn persoonlijkheidskenmerken die significant positief gerelateerd zijn aan de cursusdeelname van werknemers met een vast contract. Het is verder nog opvallend dat er bij deze groep werknemers een negatieve relatie is tussen iemands BMI en de kans op cursusdeelname. De inhoud van het werk is ook erg bepalend voor de cursusdeelname van werknemers met een vast contract. Naast de vaker gevonden positieve relaties tussen cursusdeelname en organisatorische en technologische ontwikkelingen, ${ }^{33}$ blijkt ook de mate van concurrentie op de afzetmarkt van het bedrijf waar men werkt van belang. Hoe meer concurrentie op de markt, des te lager de cursusparticipatie.

31 Het aantal respondenten in deze groep is erg klein. Hierdoor is de verklarende kracht van het model beperkt.

32 Vaak zijn de onderliggende variabelen als gevolg van het lage aantal observaties niet significant, maar zijn ze als groep wel gezamenlijk significant.

33 De correlatie tussen technologische verandering en cursusdeelname is enkel zwak significant. 
TABEL 3.12 Betekenis van specifieke HR-instrumenten voor de cursusparticipatie, naar contractvorm

\begin{tabular}{|l|c|c|c|}
\hline Afh. Var.: Training participatie & $(1)$ & $(2)$ & (3) \\
\hline Functionerings- en/of beoordelingsgesprekken & $\begin{array}{c}\text { Tijdelijk contract zonder } \\
\text { perspectief }\end{array}$ & $\begin{array}{c}\text { Tijdelijk contract met } \\
\text { perspectief }\end{array}$ & Vast contract \\
\hline Persoonlijk opleidings- of ontwikkelplan & 0,148 & $0,278^{*}$ & $0,0908^{* *}$ \\
\hline Regelmatige feedback van leidinggevende & 0,0369 & 0,0342 & $0,0905^{* * *}$ \\
\hline Regelmatige feedback door collega's & 0,204 & $-0,123$ & $-0,0346$ \\
\hline Loopbaanplan & 0,0372 & 0,109 & $0,0574^{*}$ \\
\hline Coaching & $-0,275$ & 0,142 & $-0,0350$ \\
\hline Functierotatie & 0,0217 & 0,0965 & 0,0342 \\
\hline Taakroulatie & 0,248 & $-0,0194$ & $-0,0788$ \\
\hline Detachering binnen dezelfde organisatie & 0,143 & 0,119 & $0,0782^{* *}$ \\
\hline Prestatiebeloning of bonussen & 0,389 & 0,0181 & 0,00830 \\
\hline & $-0,486$ & 0,0556 & $-0,0176$ \\
\hline N & & & 1.418 \\
\hline Totale variantie verklaard & 85 & 138 & $11,3 \%$ \\
\hline
\end{tabular}

*** $\mathrm{p}<0.01,{ }^{* *} \mathrm{p}<0.05,{ }^{*} \mathrm{p}<0.1$

Bronnen: ROA LLL Enquête, 2017; NSS, 2017; LISS, 2014-2017

Noot: coëfficiënten gebaseerd op regressiemodel waar alle clusters variabelen tegelijk zijn opgenomen.

Uit Tabel 3.12 blijkt dat er geen significante relatie is tussen individuele HR-instrumenten en cursusparticipatie van werknemers met een tijdelijk contract zonder uitzicht op vast. Zoals gezegd, zal dat mede het gevolg zijn van het geringe aantal respondenten met een dergelijk contract. Er zijn echter wel aanwijzingen voor een positieve relatie tussen cursusparticipatie enerzijds en functionerings- en/of beoordelingsgesprekken en regelmatige feedback van collega's anderzijds. De coëfficiënt zijn vrij groot en wijzen ook nog eens in dezelfde richting als de vergelijkbare coëfficiënten van de andere groepen werknemers. Hetzelfde geldt ook voor variabelen als taakroulatie en detachering binnen dezelfde organisatie. De groep werknemers met een tijdelijk contract zonder uitzicht op vast is echter te klein voor een precieze schatting van de relatie.

In Tabel 3.13 is de verklaarde variantie in het informeel leren op het werk weergegeven. De observatie dat maar liefst 22,2 procent van de variantie van het informeel leren op het werk onder werknemers met een tijdelijk dienstverband zonder uitzicht op vast werk verklaard kan worden door het totale model, steekt duidelijk af tegen de beperkte verklarende waarde van het model voor cursusparticipatie (zie Tabel 3.11). 
Net als bij zelfstandigen bepaalt ook de persoonlijkheid van werknemers met een tijdelijk contract zonder uitzicht op vast werk voor een belangrijk deel de mate van informeel leren op het werk.
Naast de standaard controlevariabelen (gedreven door opleidingsniveau), blijkt met name iemands persoonlijkheid de mate van informeel leren op het werk te kunnen verklaren. De bereidheid risico te nemen hangt positief samen met de mate van infor-

meel leren onder alle groepen. Open staan voor nieuwe ervaringen hangt positief samen met informeel leren voor tijdelijke werknemers zonder uitzicht op een vast contract en vaste medewerkers. Bevlogenheid hangt daarnaast samen met de mate van informeel leren onder tijdelijke werknemers met uitzicht op een vast contract en vaste werknemers. De inhoud van het werk verklaart een relatief groot deel van de geobserveerde variantie in het informeel leren onder tijdelijke werknemers zonder perspectief op een vast contract.

TABEL 3.13 Verklaarde variantie informeel leren op het werk naar groepen determinanten, naar contractvorm

\begin{tabular}{|l|r|r|r|}
\hline Variantie verklaard door: & $\begin{array}{r}\text { Tijdelijk contract zonder } \\
\text { perspectief }\end{array}$ & $\begin{array}{r}\text { Tijdelijk contract met } \\
\text { perspectief }\end{array}$ & $\begin{array}{r}\text { Vast contract } \\
\hline \text { Standaad controlevariabelen }\end{array} \quad 4,4 \%$ \\
\hline Persoonlijkheid & $22,1 \%$ & $2,8 \%$ & $4,2 \%$ \\
\hline Leefstijl en leefsituatie & $0 \%$ & $1,7 \%$ & $4,3 \%$ \\
\hline Inhoud werk & $15,9 \%$ & $10,3 \%$ & $0 \%$ \\
\hline HR-beleid & $1,2 \%$ & $3,8 \%$ & $6,5 \%$ \\
\hline & & $0 \%$ & $4,7 \%$ \\
\hline Totale variantie verklaard & $22,2 \%$ & & $10,1 \%$ \\
\hline N & 85 & $21,6 \%$ & 1.418 \\
\hline
\end{tabular}

Bronnen: ROA LLL Enquête, 2017; NSS, 2017; LISS, 2014-2017

Noot: verklaarde variantie is adjusted $\mathrm{R}^{2}$.

Hoewel we uit Tabel 3.13 al kunnen opmaken dat het HR-beleid nauwelijks in staat is om de variantie in het informeel leren onder tijdelijke werknemers te verklaren, laten we in Tabel 3.14 toch de specifieke relatie zien tussen de individuele HR-instrumenten en de mate van informeel leren op het werk. Uit de tabel blijkt opmerkelijk genoeg dat het hebben van een persoonlijk opleidings- en ontwikkelingsplan zwak negatief samenhangt met de mate van informeel leren onder werknemers met een tijdelijk contract zonder uitzicht op een vast contract. Hetzelfde geldt ook voor het ontvangen van regelmatige feedback van de leidinggevende, een verband dat we al geregeld zagen terugkomen. Verder blijkt de leercultuur van de organisatie sterk van invloed op de mate waarin tijdelijke werknemers zonder perspectief op een vaste aanstelling informeel leren op het werk. Deze laatste relatie met leercultuur vinden we ook terug onder vaste medewerkers, al is het effect daar veel minder sterk. Onder tijdelijke werknemers met uitzicht op vast en vaste werknemers vinden we verder geen relaties tussen HR-instrumenten en informeel leren. 
TABEL 3.14 Betekenis van specifieke HR-instrumenten in het informeel leren op het werk, naar contractvorm

\begin{tabular}{|l|c|c|c|}
\hline Afh. Var.: Informeel leren & $\begin{array}{c}(1) \\
\text { Tijdelijk contract } \\
\text { zonder perspectief }\end{array}$ & $\begin{array}{c}(2) \\
\text { Tijdelijk contract met } \\
\text { perspectief }\end{array}$ & \begin{tabular}{c} 
Vast contract \\
\hline Functionerings- en/of beoordelingsgesprekken
\end{tabular} \\
\hline Persoonlijk opleidings- of ontwikkelplan & 6,040 & 5,611 & 1,406 \\
\hline Regelmatige feedback van leidinggevende & $-23,03^{*}$ & 0,0208 & 1,161 \\
\hline Regelmatige feedback door collega's & $-18,98^{*}$ & 3,486 & $-1,739$ \\
\hline Loopbaanplan & 15,76 & 1,901 & 2,342 \\
\hline Coaching & 18,71 & $-0,515$ & 0,0336 \\
\hline Functierotatie & 5,746 & 4,916 & 0,126 \\
\hline Taakroulatie & 10,77 & $-3,352$ & 1,386 \\
\hline Detachering binnen dezelfde organisatie & $-18,87$ & 8,830 & 0,599 \\
\hline Prestatiebeloning of bonussen & 20,65 & 12,91 & 1,442 \\
\hline & $-13,45$ & $-6,675$ & 0,434 \\
\hline N & & & 1.418 \\
\hline Totale variantie verklaard & 85 & 138 & $10,1 \%$ \\
\hline
\end{tabular}

${ }^{* * *} p<0.01,{ }^{* *} p<0.05,{ }^{*} p<0.1$

Bronnen: ROA LLL Enquête, 2017; NSS, 2017; LISS, 2014-2017

Noot: coëfficiënten gebaseerd op regressiemodel waar alle clusters variabelen tegelijk zijn opgenomen 


\section{BEREIDHEID VAN WERKENDEN MET EEN KWETSBARE POSITIE OM CURSUSSEN TE VOLGEN}

In dit hoofdstuk wordt, door middel van een keuze experiment (vignet), onderzocht hoe de cursusdeelname onder werknemers met een kwetsbare positie op de arbeidsmarkt gestimuleerd kan worden. Allereerst bespreken we in paragraaf 4.1 de opzet van het gebruikte vignet, waarna we laten zien wat de gemiddelde werkende stimuleert om een cursus te gaan volgen. In paragraaf 4.2 gaan we achtereenvolgens expliciet in op de 55-66 jarige werknemers, de laagopgeleide werknemers en de werknemers met een tijdelijk contract zonder uitzicht op een vaste aanstelling. In paragraaf 4.3 gaan we in op het keuzeproces van zelfstandigen. In de daaropvolgende paragrafen bespreken we achtereenvolgens in hoeverre iemands leefstijl en leefsituatie (paragraaf 4.4) en persoonlijkheid (paragraaf 4.5) een rol spelen. Daarbij stellen we de vraag welke mensen het beste te stimuleren zijn en voor wie bepaalde belemmeringen een extra grote rol spelen.

\subsection{Stimulerende en belemmerende factoren voor cursusdeelname}

De factoren die een rol spelen bij het wel niet volgen van cursussen zijn door de onderzoeker niet altijd goed waarneembaar. In een dergelijk geval kan een realistisch keuzeexperiment informatief zijn over de manier waarop iemand voor cursussen kiest. In de ROA Levenslang Leren Enquête 2017 is een dergelijk keuze-experiment opgenomen waarbij respondenten gevraagd zijn een keuze te maken tussen twee soorten cursussen die verschillen op een aantal kenmerken (bijvoorbeeld soort vaardigheid en cursuslast). Elke respondent is drie keer gevraagd een keuze te maken tussen cursussen met verschillende kenmerken. Met deze opzet is het mogelijk om het keuzeproces inzichtelijk te maken. Zo kan worden nagegaan welke eigenschappen van een cursus stimulerend of belemmerend werken op de beslissing om een cursus te gaan volgen. De volgende situatie is aan de respondenten voorgelegd: 
"Stel dat u van uw werkgever een tegoedbon ontvangt ter waarde van 1.000 euro die u naar eigen wens mag inzetten voor het volgen van een training of cursus in de komende 12 maanden. ${ }^{34}$

Hieronder vragen wij u om 3 keer een keuze te maken uit twee mogelijke cursussen.

De cursussen verschillen op een zestal kenmerken van elkaar. ${ }^{35}$ Verder zijn de cursussen identiek aan elkaar."

Tabel 4.1 geeft een overzicht van de zes verschillende kenmerken van de trainingen waaruit men moet kiezen. Elk kenmerk heeft 3 opties, ook deze zijn in de tabel opgenomen. De opties die de respondent per cursus te zien kreeg zijn gerandomiseerd.

TABEL 4.1 Kenmerken van de training en opties binnen het werknemers vignet

\begin{tabular}{|c|c|}
\hline Kenmerken van de training & Opties \\
\hline Getrainde vaardigheden & $\begin{array}{l}\text { 1. Vaktechnische kennis en vaardigheden } \\
\text { 2. Sociale en communicatieve vaardigheden } \\
\text { 3. Loopbaanoriëntatie en coaching }\end{array}$ \\
\hline Gericht op: & $\begin{array}{l}\text { 1. Uw huidige baan } \\
\text { 2. Uw loopbaan binnen uw huidige organisatie } \\
\text { 3. Uw loopbaan buiten uw huidige organisatie }\end{array}$ \\
\hline Eigen bijdrage & $\begin{array}{l}\text { 1. } 0 \text { Euro } \\
\text { 2. } 100 \text { Euro } \\
\text { 3. } 200 \text { Euro }\end{array}$ \\
\hline Cursuslast & $\begin{array}{l}\text { 1. } 8 \text { uur onder werktijd } \\
\text { 2. } 4 \text { uur onder werktijd en } 4 \text { uur in eigen tijd } \\
\text { 3. } 8 \text { uur in eigen tijd }\end{array}$ \\
\hline Beoordeling & $\begin{array}{l}\text { 1. Geen eindtoets/ beoordeling } \\
\text { 2. Beoordeling op basis van persoonlijke inzet tijdens cursus } \\
\text { 3. Eindtoets van opgedane kennis en vaardigheden }\end{array}$ \\
\hline Cursusvorm & $\begin{array}{l}\text { 1. Klassikale lessen } \\
\text { 2. Individuele training } \\
\text { 3. Online cursus }\end{array}$ \\
\hline
\end{tabular}

De drie soorten getrainde vaardigheden maken het mogelijk om te kijken of de verschillende groepen werkenden verschillende preferenties hebben. In Hoofdstuk 5 bekijken we of deze preferenties overeenstemmen met de vaardigheden die de werkgevers belangrijk vinden bij het aanbieden van scholing. Een ander kenmerk van de cursus is in hoeverre deze gericht is op de huidige baan of op de loopbaan. Dit onderscheid is met name interessant voor 55-64 jarigen en voor werknemers met een tijdelijk dienstverband. In het vignet zijn ook twee kenmerken meegenomen die ingaan op de mate waarin een eigen bijdrage vereist is. Het gaat daarbij om een bijdrage in tijd of in geld. Het is belangrijk om te weten of een eigen bijdrage belemmerend werkt en zo ja, of een eigen de werkgever, kregen zij de situatie voorgelegd dat zij een tegoedbon kregen van de overheid. Uit analyses blijkt dat respondenten in beide situatie op een vergelijkbare manier hun keuze voor een cursus maken.

35 Niet-werkenden hebben een soortgelijk vignet gekregen. In dit hoofdstuk gaan wij echter alleen in op de werkenden. 
bijdrage voor alle groepen werkenden even belemmerend is. Ook de manier waarop de in de cursus opgedane kennis en vaardigheden beoordeeld worden is meegenomen in het vignet, omdat uit eerder onderzoek bleek dat mensen met examenvrees minder geneigd zijn om aan scholing deel te nemen (Fouarge et al., 2013). Door dit kenmerk mee te nemen in het vignet kan worden onderzocht of andere vormen van beoordeling de cursusdeelname onder mensen met examenvrees kan compenseren. De cursusvorm is meegenomen om inzicht te krijgen in de (heterogene) voorkeuren van werkenden om aan een bepaald soort cursus deel te nemen.

Een eigen financiële bijdrage of het moeten volgen van de cursus in eigen tijd belemmeren de cursusdeelname.
In Figuur 4.1 is voor elk cursuskenmerk de verandering weergegeven in de kans dat een cursus gekozen wordt. Daarbij is er voor elk kenmerk een referentiecategorie opge-

nomen. Voor de getrainde vaardigheden zijn vaktechnische kennis en vaardigheden de referentiecategorie. Uit Figuur 4.1 is op te maken dat mensen een cursus significant minder vaak kiezen (afname van 2 procentpunt) als deze betrekking heeft op sociale en communicatieve vaardigheden, of als deze ingaat op loopbaanoriëntatie en coaching, dan een cursus die gericht is op vaktechnische kennis en vaardigheden. Het maakt voor werkenden niet uit of de cursus zich richt op de huidige baan of een loopbaan binnen of buiten de huidige organisatie. De mate waarin respondenten een eigen bijdrage in termen van geld of tijd moeten leveren blijkt daarentegen wel degelijk van belang. Een eigen financiële bijdrage van 100 euro verkleint de kans om de cursus te kiezen met ongeveer 2 procentpunt, een eigen bijdrage van 200 euro zelfs met 5 procentpunt. Een cursus die gedeeltelijk in eigen tijd moet worden gevolgd, wordt niet significant minder vaak gekozen dan een cursus die geheel tijdens werktijd kan worden gevolgd. Echter, wanneer een cursus geheel in eigen tijd moet worden gevolgd dan verkleint dit de kans om de cursus gekozen wordt met 2 procentpunt ten opzichte van een cursus die men geheel in werktijd kan volgen. De manier waarop de in de cursus opgedane kennis en vaardigheden al dan niet getoetst worden blijkt voor werkenden niet van belang te zijn. Ten slotte blijkt dat men minder graag een online cursus volgt dan klassikale lessen of een individuele training. 
FIGUUR 4.1 Stimulerende en belemmerende factoren in de cursuskeuze

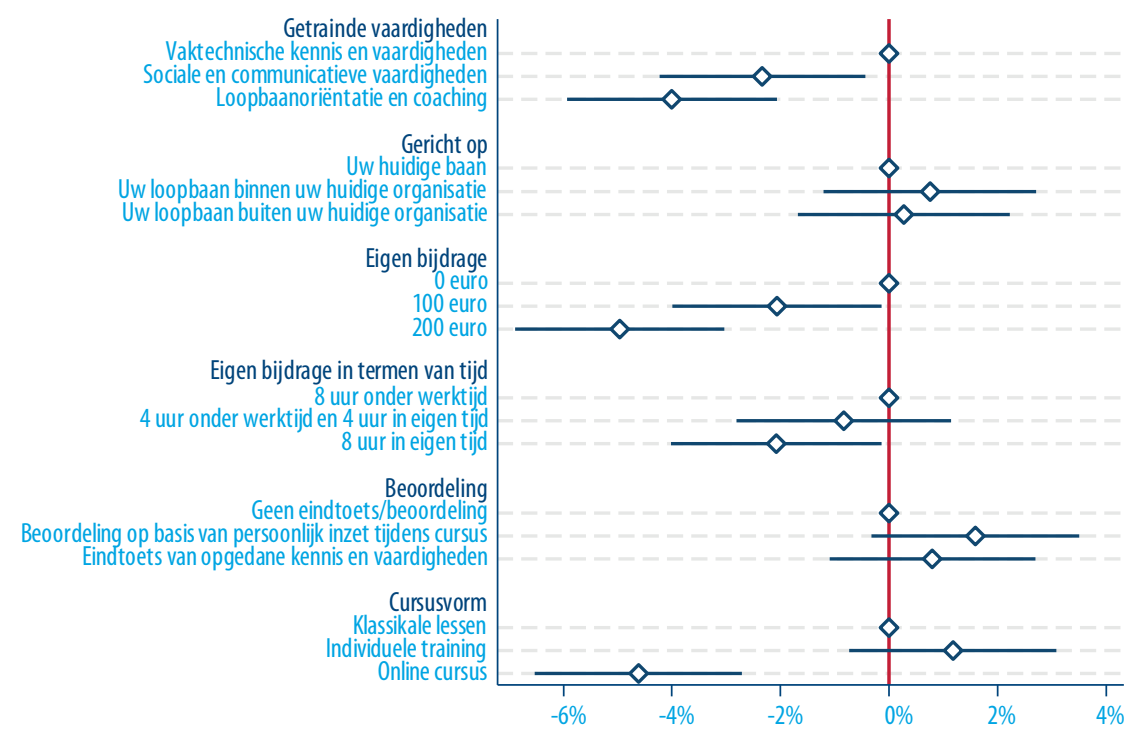

Verandering in kans dat cursus/training wordt gekozen (gemiddeld marginaal effect), inclusief $95 \%$ betrouwbaarheidsinterval

Bron: ROA LLL Enquête, 2017

Noot: gebaseerd op probit analyses met cluster-robuuste standaardfouten.

Om inzichtelijk te krijgen wat de stimulerende en belemmerende factoren in de cursuskeuze zijn, moeten respondenten in het vignetexperiment een keuze maken uit twee voorgelegde cursussen. Echter, de vraag of men de gekozen cursus ook daadwerkelijk zou gaan volgen mocht deze in de realiteit aangeboden worden is natuurlijk een andere vraag. Daarom hebben wij na elke cursuskeuze nog een vervolgvraag gesteld: Zou u deze cursus ook daadwerkelijk gaan volgen? In Tabel 4.2 is weergegeven hoe vaak respondenten de cursus ook daadwerkelijk zouden gaan volgen als deze in realiteit aangeboden zou worden. lets meer dan een kwart van alle respondenten geeft aan geen van de gekozen cursussen daadwerkelijk te willen gaan volgen als deze hen in de realiteit zou worden aangeboden. 15 procent van de respondenten zou één van de drie gekozen cursussen daadwerkelijk willen volgen; 21 procent twee van de drie gekozen cursussen en 37 procent zou alle drie de gekozen cursussen daadwerkelijk willen volgen.

TABEL 4.2 Voornemen om gekozen cursussen uit vignet daadwerkelijk te volgen

\begin{tabular}{|l|l|}
\hline Aantal keer dat respondenten de gekozen cursus daadwerkelijk willen volgen & $\%$ \\
\hline 0 keer & 27 \\
\hline 1 keer & 15 \\
\hline 2 keer & 21 \\
\hline 3 keer & 37 \\
\hline
\end{tabular}

Bron: ROA LLL Enquête, 2017 
Er is een sterke relatie tussen het daadwerkelijke traingedrag en de bereidheid om een binnen het vignet gekomen cursus daadwerkelijk te volgen.

Er blijkt een duidelijke relatie te zijn tussen het aantal keer dat men de gekozen cursus ook daadwerkelijk wil gaan volgen en het feitelijke cursusdeelname in de afgelopen twee jaar. Tabel 4.3 laat zien dat van degenen die geen van de in het vignet gekozen cursussen daadwerkelijk willen gaan volgen slechts 38 procent de afgelopen twee jaren een cursus heeft gevolgd en 41 procent zelfs nog nooit een cursus heeft gevolgd sinds het verlaten van school. Onder de respondenten die minimaal 1 keer de gekozen cursus ook daadwerkelijk willen gaan volgen, heeft 60 procent in de afgelopen twee jaar ook daadwerkelijk een cursus gevolgd en is het percentage dat nog nooit een cursus heeft gevolgd met 21 procent veel lager. Het aantal cursussen dat iemand in de afgelopen twee jaar heeft gevolgd loopt ook iets op naarmate iemand vaker bereid is de binnen het vignet gekozen cursussen te gaan volgen.

TABEL 4.3 Relatie tussen voornemen om gekozen cursus uit vignet daadwerkelijk te volgen en het trainingsgedrag

\begin{tabular}{|l|r|r|r|}
\hline $\begin{array}{l}\text { Aantal keer daadwerkelijk volgen van } \\
\text { gekozen cursus }\end{array}$ & $\begin{array}{r}\text { nog nooit een training } \\
\text { gevolgd }\end{array}$ & $\begin{array}{r}\text { cursusdeelname in de } \\
\text { afgelopen twee jaar } \\
\%\end{array}$ & $\begin{array}{r}\text { Gemiddeld aantal } \\
\text { cursussen in de afgelopen } \\
\text { twee jaar }\end{array}$ \\
\hline 0 keer & 41 & 38 & 0,95 \\
\hline 1 keer & 21 & 59 & 1,76 \\
\hline 2 keer & 21 & 59 & 1,75 \\
\hline 3 keer & 21 & 60 & 1,81 \\
\hline
\end{tabular}

Bron: ROA LLL Enquête, 2017

\subsection{Verschillen naar kwetsbare positie op de arbeidsmarkt}

In Figuur 4.2 worden de stimulerende en belemmerende factoren voor de cursuskeuze apart weergegeven voor de drie groepen werknemers met een kwetsbare positie op de arbeidsmarkt. ${ }^{36}$ Op die manier kunnen we kijken of de in paragraaf 4.1 gevonden stimulerende en belemmerende factoren ook gelden voor de 55-66 jarige werknemers, de laagopgeleide werknemers en de werknemers met een tijdelijk dienstverband zonder uitzicht op vast.

Figuur 4.2 laat zien dat er slechts kleine, maar wel interessante verschillen zijn tussen de groepen werkenden. Zo zijn alleen voor de laagopgeleide werknemers de sociale en communicatieve cursussen minder geliefd dan de cursussen die gericht zijn op vaktechnische kennis en vaardigheden. De werknemers in de leeftijd van 55-66 jaar en degenen met een tijdelijk dienstverband zonder uitzicht op vast, blijken geen voorkeur te hebben voor vaktechnische of sociaal-communicatieve cursussen. Laagopgeleide werknemers en 55-plusser kiezen weer minder snel een cursus die gericht is op loopbaanoriëntatie en

36 In paragraaf 4.3 gaan we in op de zelfstandigen. 
coaching, terwijl werkenden met een tijdelijk dienstverband zonder uitzicht op vast juist vaker voor een dergelijke cursus kiezen.

Werknemers met een tijdelijk dienstverband zonder uitzicht op een vast contract laten zich in hun cursuskeuze niet beïnvloeden door een eigen bijdrage in termen van geld of tijd. Dit geldt wel voor laagopgeleide en 55-66 jarige werknemers.
Ook de observatie dat een cursus minder aantrekkelijk wordt voor werknemers als zij een eigen bijdrage in termen van tijd of geld moeten leveren geldt niet voor alle groepen werknemers. Wederom blijkt dat werknemers met een tijdelijk dienstverband zonder uitzicht op een vast contract een cursus niet minder vaak kiezen als zij een eigen bijdrage in termen van geld of tijd moeten leveren. Het soort getrainde vaardigheden blijkt voor hen belangrijker in de keuze voor een cursus dan beide vormen van een eigen bijdrage.

FIGUUR 4.2 Stimulerende en belemmerende factoren in de cursuskeuze, voor 55-66 jarigen, laagopgeleiden en werknemers met een tijdelijk dienstverband zonder uitzicht op vast

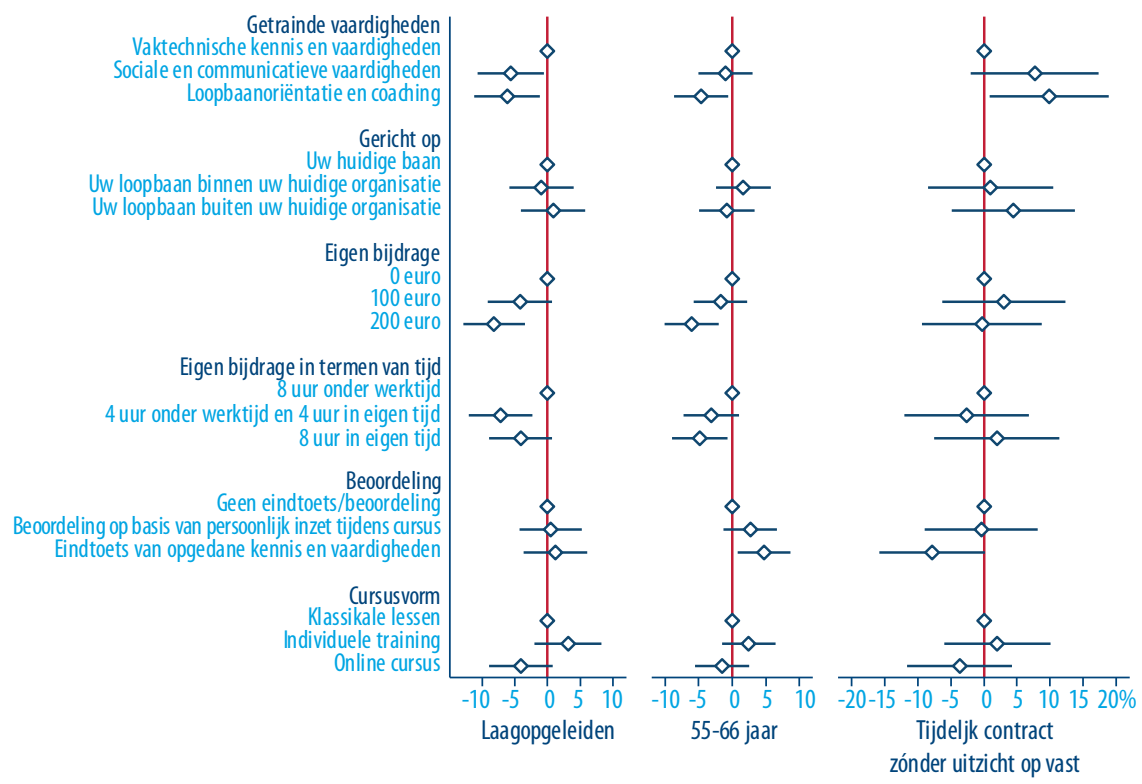

Verandering in kans dat cursus/training wordt gekozen (gemiddeld marginaal effect), inclusief $95 \%$ betrouwbaarheidsinterval

Bron: ROA LLL Enquête, 2017

Noot: gebaseerd op probit analyses met cluster-robuuste standaardfouten. 
Er zijn weinig verschillen in de stimulerende en belemmerende factoren voor de cursuskeuze tussen werknemers met een zwakke positie op de arbeidsmarkt en werknemers met een goede positie.

Het is opmerkelijk dat de stimulerende en belemmerende factoren voor de cursusdeelname in het algemeen weinig verschillen tussen de verschillende groepen werkenden. Als we de kwetsbare groepen vergelijken met hun referentiegroepen, vinden we alleen kleine of zelfs geen significante verschillen. ${ }^{37}$ Terwijl we voor 55 -plussers vinden dat een cursus die geheel in eigen tijd gevolgd moet worden significant minder vaak gekozen wordt, vinden we dit niet voor de andere leeftijdsgroepen..$^{38}$ We vinden geen verschillen in de stimulerende en belemmerende factoren tussen laagopgeleiden en middelbaaren hoogopgeleiden. Net als voor werknemers in vaste dienst, en in tegenstelling tot werknemers met een tijdelijk contract zonder uitzicht op vast, wordt een cursus die gericht is op loopbaanoriëntatie en coaching significant minder vaak gekozen door werknemers met een tijdelijk contract met uitzicht op vast dan een cursus die inzet op vaktechnische kennis en vaardigheden. Wat betreft de eigen bijdrage in termen van geld en tijd is er juist een verschil tussen aan de ene kant de werkenden met een tijdelijk contract (met of zonder uitzicht op vast) en de mensen met een vast dienstverband.

Hoewel er dus weinig verschil is in de mate waarin werknemers te stimuleren zijn om een cursus te volgen, is het desalniettemin interessant om ook hier te kijken naar de mate waarin de binnen het vignet gekozen cursus ook daadwerkelijk gevolgd zou worden. ${ }^{39}$ In Figuur 4.3 is voor elke categorie werkenden het percentage weergegeven dat de gekozen cursus ook daadwerkelijk zou willen volgen. Hier zien we grote verschillen tussen de 55-plussers en de werknemers die jonger zijn. Van de 55-plussers geeft 40 procent aan geen enkele keer de uitgekozen cursussen daadwerkelijk te willen volgen; voor de andere leeftijdsgroepen ligt dit percentage bijna de helft lager. Bovendien zou maar 30 procent van de 55-plussers alle drie de gekozen cursussen daadwerkelijk willen volgen, tegenover 40 procent van de jongere werknemers.

37 Zie Bijlage B voor de figuren B.1-B.3 waarin we de referentiegroepen leggen naast de desbetreffende werknemers met een kwetsbare positie op de arbeidsmarkt.

38 De verschillen tussen de drie leeftijdsgroepen zijn echter klein en niet significant.

39 Als we de stimulerende en belemmerende factoren analyseren op basis van gekozen cursussen die men ook daadwerkelijk zou willen volgen, blijven de resultaten gelijk. 
FIGUUR 4.3 Voornemen om gekozen cursus uit vignet daadwerkelijk te gaan volgen, naar type werknemer

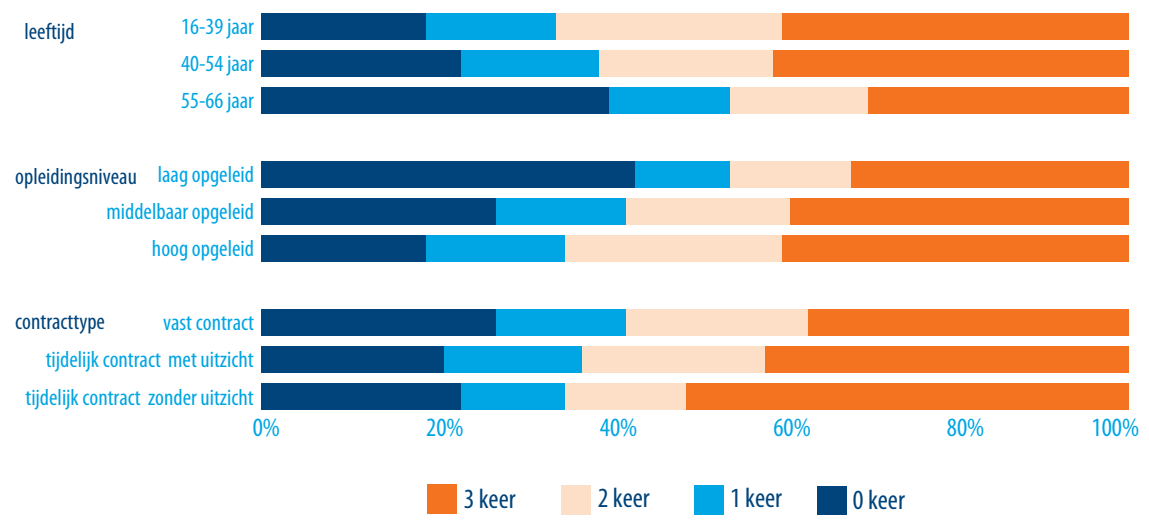

Bron: ROA LLL Enquête, 2017

Ook de laagopgeleiden willen minder vaak de binnen het vignet gekozen cursus daadwerkelijk volgen. De verschillen zijn hier groot. Terwijl 43 procent van de laagopgeleiden geen van de gekozen opleidingen daadwerkelijk zou willen volgen, wil slechts 27 procent van de middelbaaropgeleiden en 19 procent van de hoogopgeleiden dit ook niet doen. Daar tegenover staat dat de hoogopgeleiden significant vaker alle drie de gekozen cursussen daadwerkelijk zouden willen volgen dan de laagopgeleiden.

De verschillen tussen 55-plussers en laagopgeleiden aan de ene kant en hun referentiegroepen aan de andere kant, komen overeen met hun feitelijke cursusdeelname. $\mathrm{Er}$ is zowel een significante relatie met het percentage dat nog nooit een training heeft gevolgd als met de cursusdeelname in de afgelopen twee jaar.

Onder werknemers met een tijdelijk contract zonder uitzicht op vast werk is de bereidheid om een cursus te volgen erg groot, maar er is geen significante relatie tussen het aantal binnen het vignet gekozen cursussen die zij daadwerkelijk zouden willen volgen en hun daadwerkelijke cursusparticipatie. Dit suggereert dat hun lagere trainingsdeelname het gevolg is van een geringere bereidheid van werkgevers om cursussen aan te bieden.
Dit staat in schril contrast met de resultaten voor de werknemers met een tijdelijk dienstverband zonder uitzicht op een vast contract. Voor hen zien we in Figuur 4.4 juist dat zij significant vaker alle drie de binnen het vignet gekozen cursussen daadwerkelijk zouden willen volgen dan de werknemers met een vast contract. ${ }^{40}$ Hun scholingsbereidheid is dus groot. Bovendien ontbreekt voor de werknemers met een tijdelijk dienstverband zonder uitzicht op een vast contract

$40 \mathrm{Er}$ is geen significant verschil in het aantal keer dat de gekozen cursus ook daadwerkelijk gevolgd zou worden tussen werknemers met een tijdelijk contract met en zonder uitzicht op vast. 
een significante relatie tussen het aantal binnen het vignet gekozen cursussen die zij daadwerkelijk zouden willen volgen en hun daadwerkelijke cursusdeelname. Dit suggereert dat met name voor de werknemers met een tijdelijk dienstverband zonder uitzicht op een vast contract, de lagere trainingsparticipatie (zie Hoofdstuk 2), niet gedreven wordt door een lage scholingsbereidheid, maar eerder het gevolg is van een geringere bereidheid van werkgevers om cursussen aan te bieden. In Hoofdstuk 5 gaan we hier, op basis van een werkgeversvignet, verder op in.

Tabel 4.4 laat voor de werkenden met de verschillende typen dienstverbanden zien welke factoren van invloed zijn op het voornemen om de in het vignet gekozen cursus daadwerkelijk te gaan volgen. ${ }^{41}$ Het is opvallend dat de leefstijl en leefsituatie van werknemers met een tijdelijk dienstverband zonder uitzicht op een vast contact een relatief groot deel van de variantie in het aantal binnen het vignet gekozen cursussen dat men daadwerkelijk zou willen volgen verklaart. Ook het HR-beleid speelt een relatief grote rol voor deze tijdelijke werknemers. Als werknemers met een tijdelijk contract zonder uitzicht op een vast contract regelmatig feedback krijgen van collega's zijn ze vaker bereid om meer cursussen daadwerkelijk te gaan volgen, al dient opgemerkt te worden dat deze relatie slechts zwak significant is.

Persoonskenmerken, persoonlijkheid, leefstijl en leefsituatie, inhoud van het werk en HR-beleid zijn veel meer in staat om de bereidheid van werknemers met een tijdelijk dienstverband zonder uitzicht op een vast contract te verklaren dan hun daadwerkelijke traingedrag.
Een vergelijking met Tabel 3.11 laat zien dat de totale variantie die, voor werknemers met een tijdelijk contract, verklaard kan worden door standaard controlevariabelen, persoonlijkheid, leefstijl en leefsituatie, inhoud van het werk en het HR-beleid, veel groter is in een model dat voorgenomen cursusdeelname probeert te verklaren

(Tabel 4.4) dan een model dat daadwerkelijk cursusgedrag probeert te verklaren (Tabel 3.11). Terwijl alle potentiële determinanten samen slechts de helft van de variantie onder werknemers met een tijdelijk dienstverband zonder uitzicht op vast contract vergeleken met werknemers met een vast contract kon verklaren, is dit hier niet meer het geval. De verklaarde variantie van het model voor de werknemers met een tijdelijk contract zonder uitzicht op vast is bijna 4 procentpunt groter dan die van de werknemers met een vast dienstverband. De totale verklaarde variantie voor tijdelijke werknemers met uitzicht op een vast contract is zelfs meer dan twee keer zo groot als voor werknemers met een vast contract.

41 Omdat er voor de 55-66 jarigen en de laagopgeleiden een sterke relatie is tussen het daadwerkelijk trainingsgedrag (zie Hoofdstuk 2) en de bereidheid om een binnen het vignet gekozen cursus daadwerkelijk te volgen, analyseren we voor deze groepen de determinanten van deze bereidheid niet. 
TABEL 4.4 Determinanten van het aantal binnen het vignet gekozen cursussen dat men daadwerkelijk zou willen volgen, naar type dienstverband

\begin{tabular}{|l|r|r|r|}
\hline Variantie verklaard door: & $\begin{array}{r}\text { Tijdelijk contract zonder } \\
\text { perspectief }\end{array}$ & $\begin{array}{r}\text { Tijdelijk contract met } \\
\text { perspectief }\end{array}$ & Vast contract \\
\hline Standaad controlevariabelen & $3,4 \%$ & $1,6 \%$ & $5,4 \%$ \\
\hline Persoonlijkheid & $6,1 \%$ & $10,3 \%$ & $6,2 \%$ \\
\hline Leefstijl en leefsituatie & $5,9 \%$ & $0 \%$ & $0 \%$ \\
\hline Inhoud werk & $4,8 \%$ & $9,5 \%$ & $5,5 \%$ \\
\hline HR-beleid & $7 \%$ & $4,6 \%$ & $1,3 \%$ \\
\hline & & & $11,7 \%$ \\
\hline Totale variantie verklaard & $15,9 \%$ & $25,4 \%$ & 1418 \\
\hline N & 85 & 138 & \\
\hline
\end{tabular}

Bronnen: ROA LLL Enquête, 2017; NSS, 2017; LISS, 2014-2017

Noot: verklaarde variantie is adjusted $\mathrm{R}^{2}$.

\subsection{Stimulerende en belemmerende factoren voor zelfstandigen}

Ook aan zelfstandigen is gevraagd om drie keer een keuze te maken tussen twee mogelijke cursussen. De attributen en opties zijn dezelfde als voor de werknemers (zie paragraaf 4.1). Het enige verschil is dat de voorgestelde cursussen bij het vignet voor zelfstandigen altijd aangeboden worden door de overheid. In Figuur 4.4 zijn de hoofdresultaten voor het vignet weergegeven. 
FIGUUR 4.4 Stimulerende en belemmerende factoren in de cursuskeuze, voor zelfstandigen

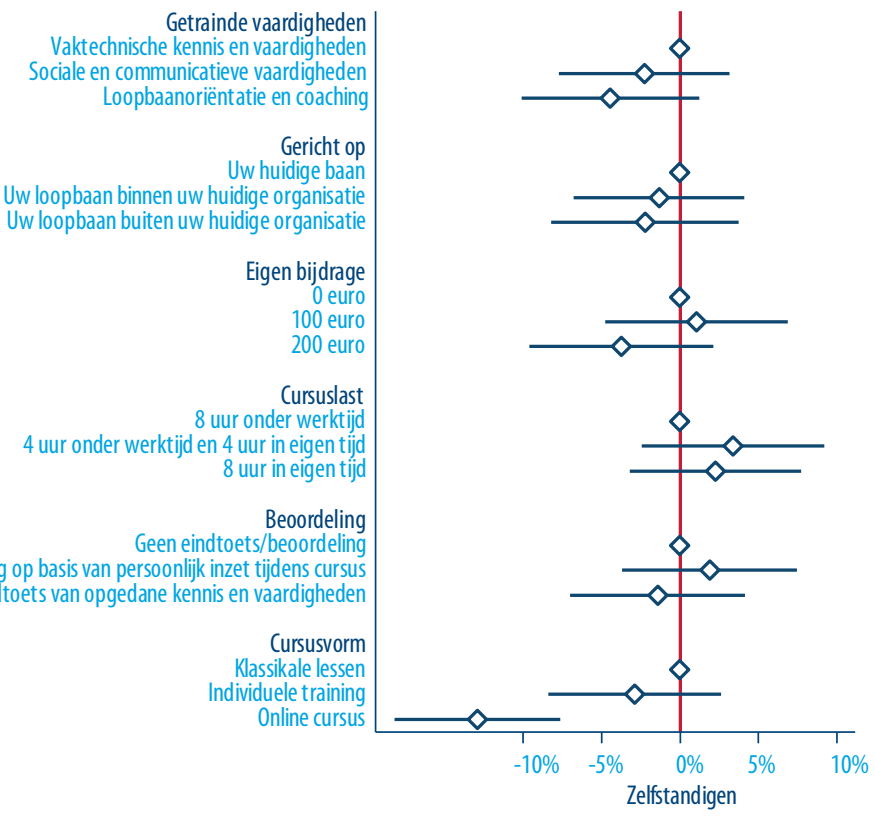

Bron: ROA LLL Enquête, 2017

Noot: gebaseerd op probit analyses met cluster-robuuste standaardfouten.

Zelfstandigen laten zich in hun cursuskeuze niet leiden door de in het vignet opgenomen attributen zoals een eigen bijdrage in tijd of geld.
Uit de figuur blijkt dat zelfstandigen zich in hun cursuskeuze niet laten leiden door de in het vignet opgenomen attributen. De getrainde vaardigheden, de loopbaan waarop de cursus zich richt, de eigen bijdrage in termen van geld en tijd en de manier van beoordeling van de cursus blijken allemaal insignificant. De enige uitzondering is de cursusvorm. Evenals de werknemers blijken ook de zelfstandigen duidelijk minder vaak te kiezen voor online cursussen.

35 procent van alle zelfstandigen zou geen enkele van de binnen het vignet gekozen cursussen daadwerkelijk willen volgen. 17 procent zou één van de gekozen cursussen willen gaan volgen en 18 procent twee van de gekozen cursussen. Ruim 40 procent zou alle drie de gekozen cursussen daadwerkelijk willen volgen. Net als voor de 55-plussers en de laagopgeleiden is er ook bij de zelfstandigen een significante correlatie tussen de feitelijke cursusparticipatie en het daadwerkelijk willen volgen van de binnen het vignet gekozen cursussen. 


\subsection{Is de bereidheid tot eigen bijdrage afhankelijk van iemands leefsituatie of leefstijl?}

Omdat uit de voorgaande paragrafen blijkt dat werkenden met een kwetsbare positie op de arbeidsmarkt een vergelijkbare waarde hechten aan de kenmerken van cursussen, bekijken we hier voor de gehele groep werknemers in hoeverre de bereidheid om eigen bijdrage in termen van geld en eigen tijd te leveren afhankelijk is van iemands leefsituatie en leefstijl. Is de mate waarin een eigen bijdrage in termen van geld en tijd voor werknemers met (maar ook zonder) een kwetsbare positie op de arbeidsmarkt een belemmering vormt om een cursus te gaan volgen afhankelijk van hun leefsituatie of leefstijl?

\section{Leefsituatie}

Figuur 4.5 laat zien dat de mate waarin een eigen financiële bijdrage een rol speelt in het keuzeproces niet verschilt tussen mensen met en zonder thuiswonende kinderen. De eigen bijdrage in termen van tijd blijkt daarentegen wel een andere rol te spelen. Terwijl de eigen bijdrage in termen van tijd helemaal niet meespeelt in de keuze van werknemers zonder thuiswonende kinderen, is dit voor werknemers met thuiswonende kinderen wel een belemmering. Als een cursus geheel in eigen tijd moet worden gevolgd neemt de kans dat werknemers met thuiswonende kinderen deze cursus kiezen met bijna 4 procentpunt af. Dit resultaat impliceert dat de in paragraaf 4.2 gevonden lagere bereidheid om een cursus te kiezen die geheel buiten werktijd gevolgd moet worden, helemaal is toe te schrijven aan de werkenden met thuiswonende kinderen.

We hebben geanalyseerd of een dergelijk verschil ook gevonden wordt tussen mensen die naast hun werk al dan niet nog vrijwilligerswerk en/of mantelzorg verrichten. Dit bleek niet het geval. Ook is er geen verschil tussen werkenden met een deeltijdbaan en voltijdswerkenden. 
FIGUUR 4.5 Stimulerende en belemmerende factoren in de cursuskeuze, voor werknemers met en zonder thuiswonende kinderen

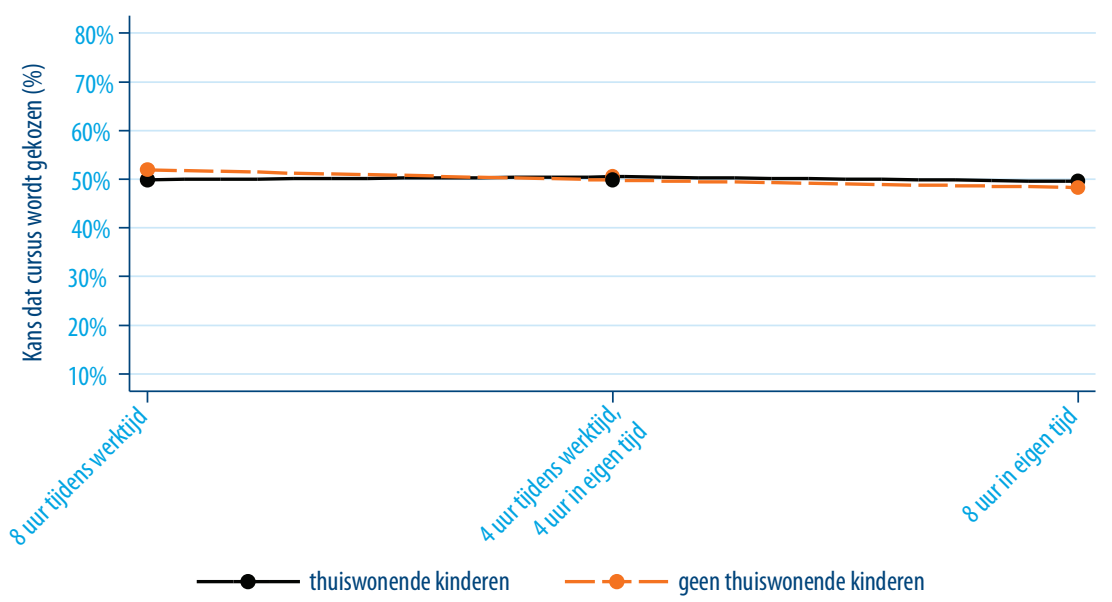

Bron: ROA LLL Enquête, 2017

Noot: gebaseerd op probit analyses met cluster-robuuste standaardfouten.

\section{Leefstijl}

Leefstijl, gemeten door het al dan niet hebben van een extreem BMI en het al dan niet roken, blijkt niet van invloed te zijn op de belemmerende rol die een cursus in eigen tijd of met eigen financiële middelen heeft op de cursuskeuze. ${ }^{42}$

\subsection{Is de bereidheid tot eigen bijdrage afhankelijk van iemands persoonlijkheid?}

In deze paragraaf gaan we in op de vraag of de mate waarin een eigen bijdrage in termen van geld en tijd voor werknemers met (maar ook zonder) een kwetsbare positie op de arbeidsmarkt een belemmering vormt om een cursus te gaan volgen afhankelijk is van iemands persoonlijkheid en economische voorkeuren.

\section{Persoonlijkheid}

De mate waarin een eigen bijdrage in termen van geld en tijd voor werknemers met een kwetsbare positie op de arbeidsmarkt een belemmering vormt om een cursus te gaan volgen blijkt nauwelijks afhankelijk van hun persoonlijkheid. ${ }^{43}$ Alleen de mate waarin men anderen vertrouwd blijkt relevant te zijn in deze context. Werkenden met een hoge mate van vertrouwen blijken namelijk meer bereid om een cursus te kiezen als hier een eigen bijdrage (van $€ 100$ of $€ 200$ ) aan verbonden is dan werkenden met een laag niveau van vertrouwen in anderen. Met andere woorden, hoe groter het vertrouwen in

42 Een extreem BMI is gedefinieerd als een BMI onder de 18,5 of gelijk aan en groter dan 30.

43 We hebben alle persoonlijkheidsindicatoren bekeken die ook in de hoofdstukken 2 en 3 aan bod komen. Het betreft: examenvrees, besluiteloosheid, bevlogenheid, positieve reciprociteit, vertrouwen en de big 5 persoonlijkheidskenmerken. 
anderen, hoe kleiner de belemmerende rol van een eigen financiële bijdrage. Een dergelijke relatie wordt niet gevonden voor de eigen bijdrage in termen van tijd.

\section{Economische voorkeuren}

lemands risicovoorkeur blijkt inderdaad belangrijk bij de belemmerende rol die een eigen bijdrage in geld en tijd spelen in een cursuskeuze. Het negatieve effect van de eis om een deel van een cursus in eigen tijd te volgen is significant kleiner voor mensen die meer bereid zijn risico's te nemen. Er blijkt geen afname te zijn in de belemmerende rol die een eigen financiële bijdrage met zich mee brengt naarmate men meer bereid is risico's te nemen.

Er blijkt ook geen verschil te zijn in de belemmerende rol die een eigen bijdrage in termen van eigen tijd speelt voor cursusdeelname tussen mensen met een hoge en lage tijdsvoorkeur. ${ }^{44}$ Daarentegen is de negatieve rol die een eigen tijdsinvestering speelt in de cursusdeelname significant kleiner voor mensen met een lagere tijdsvoorkeur. Personen die meer op de toekomst gericht zijn laten zich dus minder afschrikken door een eigen bijdrage in termen van tijd.

44 Een hoge tijdsvoorkeur houdt in dat het heden belangrijker is dan de toekomst. Een lage tijdsvoorkeur daarentegen houdt in dat men relatief veel waarde aan de toekomst hecht. 


\section{INVESTERINGSBEREIDHEID VAN WERKGEVERS}

In dit hoofdstuk staat de bereidheid van werkgevers om te investeren in de scholing van personen met een kwetsbare positie op de arbeidsmarkt centraal. Om hierover uitspraken te kunnen doen zijn binnen de ROA Werkgeversenquête Scholingsbeleid 2017 drie vignetstudies opgenomen waarvan de resultaten in dit hoofdstuk besproken worden. In paragraaf 5.1 bekijken we de bereidheid van werkgevers om in 60-jarige werknemers te investeren. Daarbij kijken we ook of deze bereidheid groter is als de 60-jarige werknemer goed presteert op het werk of over een goede motivatie beschikt. Paragraaf 5.2 richt zich op de bereidheid van werkgevers om scholing aan te bieden aan laagopgeleide werknemers. Ook wordt gekeken naar het beeld dat werkgevers hebben van de leermotivatie en het leervermogen van laagopgeleiden en in hoeverre dit beeld bepalend is voor hun bereidheid om in deze groep te investeren. In paragraaf 5.3 gaan we in op de bereidheid vanuit werkgevers om scholing aan te bieden aan werknemers met een tijdelijk arbeidscontract. Er wordt onder andere gekeken naar de mogelijkheid deze bereidheid te vergroten door het invoeren van een terugbetalingsverplichting van de scholingskosten als de medewerker vroegtijdig het bedrijf verlaat.

\subsection{Bereidheid om in 60-jarigen te investeren}

Het eerste vignetexperiment heeft betrekking op de bereidheid van werkgevers om te investeren in de scholing van werknemers uit verschillende leeftijdscategorieën. Daarbij richten we ons op de vraag in welke mate werkgevers minder bereid zijn om in de scholing van een 60-jarige medewerker te investeren dan in de scholing van een 30 of 45-jarige medewerker. Onze analyses tonen aan dat werkgevers significant minder bereid zijn om in de scholing van een 60-jarige weknemer te investeren. Dit suggereert dat de in Hoofdstuk 2 geobserveerde lagere trainingsparticipatie onder oudere werknemers deels verklaard kan worden door een lagere bereidheid onder werkgevers om in oudere werknemers te investeren.

\section{Opzet vignetexperiment}

In een eerste vignet wordt aan de werkgevers gevraagd om bij het aanbieden van scholing drie keer een keuze te maken tussen twee werknemers die van elkaar verschillen op een viertal kenmerken: leeftijd, omvang van de werkweek, de evaluatie huidige performance door leidinggevende en de evaluatie werkmotivatie door leidinggevende. 
In de vragenlijst werden de vignetexperimenten als volgt geïntroduceerd:

"Er volgen nu een aantal situaties waarin wij u 2 medewerkers voorleggen die in aanmerking komen voor het volgen van scholing (cursus of training). De medewerkers verschillen slechts op een aantal kenmerken van elkaar. Verder zijn de medewerkers identiek. Wij vragen u aan welke van deze twee medewerkers u de voorkeur geeft voor het aanbieden van scholing.

Als u geen medewerker hebt die aan de genoemde kenmerken voldoet, probeert u zich in te beelden hoe u zou kiezen als u deze medewerker wel in dienst zou hebben."

Vervolgens werd de specifieke context van het eerste keuze experiment nader toegelicht:

"We vragen u $[\ldots]$ ] keer een keuze te maken tussen 2 medewerkers voor het volgen van scholing (cursus of training) die 16 uur duurt en $€ 2.000$,- kost. De medewerkers verschillen [... ] op de volgende kenmerken:

- Evaluatie huidige performance door leidinggevende

- Evaluatie werkmotivatie door leidinggevende

- Leeftijd medewerker

- Omvang werkweek medewerker"

Tabel 5.1 geeft een overzicht van de vier kenmerken waarop de werknemers verschillen. Elk kenmerk heeft drie onderliggende waardes die telkens gerandomiseerd worden. Bij de leeftijd van de werknemer is gekozen voor de leeftijden 30, 45 en 60 jaar. ${ }^{45}$

TABEL 5.1 Kenmerken en onderliggende waardes in het vignetexperiment met betrekking tot de leeftijd van medewerkers

\begin{tabular}{|l|l|}
\hline Kenmerk & Opties \\
\hline Evaluatie huidige performance door leidinggevende & $\begin{array}{l}\text { 1. Matig } \\
\text { 2. Voldoende } \\
\text { 3. Goed }\end{array}$ \\
\hline Evaluatie werkmotivatie door leidinggevende & $\begin{array}{l}\text { 1. Matig } \\
\text { 2. Voldoende } \\
\text { 3. Goed }\end{array}$ \\
\hline Leeftijd werknemer & $\begin{array}{l}\text { 1. } 30 \text { jaar } \\
\text { 2. } 45 \text { jaar }\end{array}$ \\
\hline Omvang werkweek werknemer & 3.60 jaar \\
\hline 1. Werkt 5 dagen van 8 uur per week \\
2. Werkt 4 dagen van 8 uur per week \\
3. Werkt 3 dagen van 8 uur per week
\end{tabular}

45 In dit rapport hebben tot nu toe steeds de leeftijdsgroepen 16-39 jaar, 40-54 jaar en 55-66 jaar centraal gestaan. Voor de duidelijkheid is hier echter gekozen om elke leeftijdsgroep te representeren met één specifieke leeftijd. 
Vanuit de theorie van het menselijk kapitaal (Becker, 1964) zou verwacht kunnen worden dat werkgevers minder bereid zijn om in ouderen te investeren aangezien de verwachte duur waarin nog van deze investering geprofiteerd kan worden begrensd wordt door de naderende pensioengerechtigde leeftijd. Daarnaast blijkt dat werkgevers de productiviteit van ouderen vaak lager inschatten dan de productiviteit van jongeren (Van Dalen \& Schippers, 2010). Ook dit zal de bereidheid om in oudere werknemers te investeren naar verwachting verkleinen.

Naast de leeftijd van de werknemer zijn er nog drie andere kenmerken opgenomen in het vignet. De omvang van de werkweek is meegenomen omdat oudere werknemers in verschillende cao's nog gebruik kunnen maken van doorbetaalde arbeidsduurverkorting, leeftijdvakantiedagen of seniorenverlof. Ouderen kunnen er bovendien voor kiezen om gebruik te maken van deeltijdpensioen. ${ }^{46}$ Net als bij werkenden met een hogere leeftijd geldt dat werkgevers mogelijk minder sterk profiteren van een scholingsinvestering in iemand die deeltijd werkt dan in iemand die voltijds werkt; er zijn immers minder uren waarin van de eventuele productiviteitswinst geprofiteerd kan worden. Binnen het vignet is het dus mogelijk om te analyseren of werknemers met deeltijdpensioen een extra nadeel hebben als het gaat om de bereidheid van werkgevers om hen een cursus aan te bieden. Ook zijn er twee kenmerken opgenomen die betrekking hebben op de werkmotivatie en de performance van werknemers. Het idee hierachter is dat een werkgever waarschijnlijk eerder scholing aanbiedt aan een meer gemotiveerde medewerker. Ook zou een werkgever werknemers met een betere performance eerder een scholing kunnen aanbieden als beloning voor de goede prestaties (Armstrong-Stassen \& Ursel, 2009). Een hogere performance zou in dat geval ook een compenserende rol kunnen spelen om in de scholing van oudere werknemers te investeren. Werkgevers zouden echter ook geneigd kunnen zijn juist eerder te investeren in de scholing van werknemers met een slechtere performance, om hun performance door middel van deze scholing te verbeteren.

\section{Bereidheid tot investeren naar werknemerskenmerken}

In Figuur 5.1 is voor elk werknemerskenmerk aangegeven in hoeverre een werknemer met dit kenmerk een grotere of juist kleinere kans heeft om scholing aangeboden te krijgen. Deze grotere of kleinere kans is altijd gegeven ten opzichte van een bepaalde referentiewaarde. Deze referentiewaarde is telkens de eerst genoemde waarde van het bijbehorende kenmerk (zie Tabel 5.1). In het geval van leeftijd is de referentiewaarde dus een medewerker van 30 jaar.

46 Volgens het CBS (2017) werkte in 2016 ruim 47\% van alle werkende in de leeftijdscategorie 55 tot en met 65 jaar in deeltijd, d.w.z. gemiddeld minder dan 35 uur per week. Bron: http://statline.cbs.nl/ Statweb/publication/?VW=T\&DM $=S L N L \& P A=82647$ ned\&D1=0-1\&D2=0\&D3=0,7-8\&D4=69\&HD=171129$1324 \& H D R=G_{3}, T \& S T B=G 1, G 2 \& P=T$. 
FIGUUR 5.1 Effect van verschillende werknemerskenmerken op de kans om scholing aangeboden te krijgen

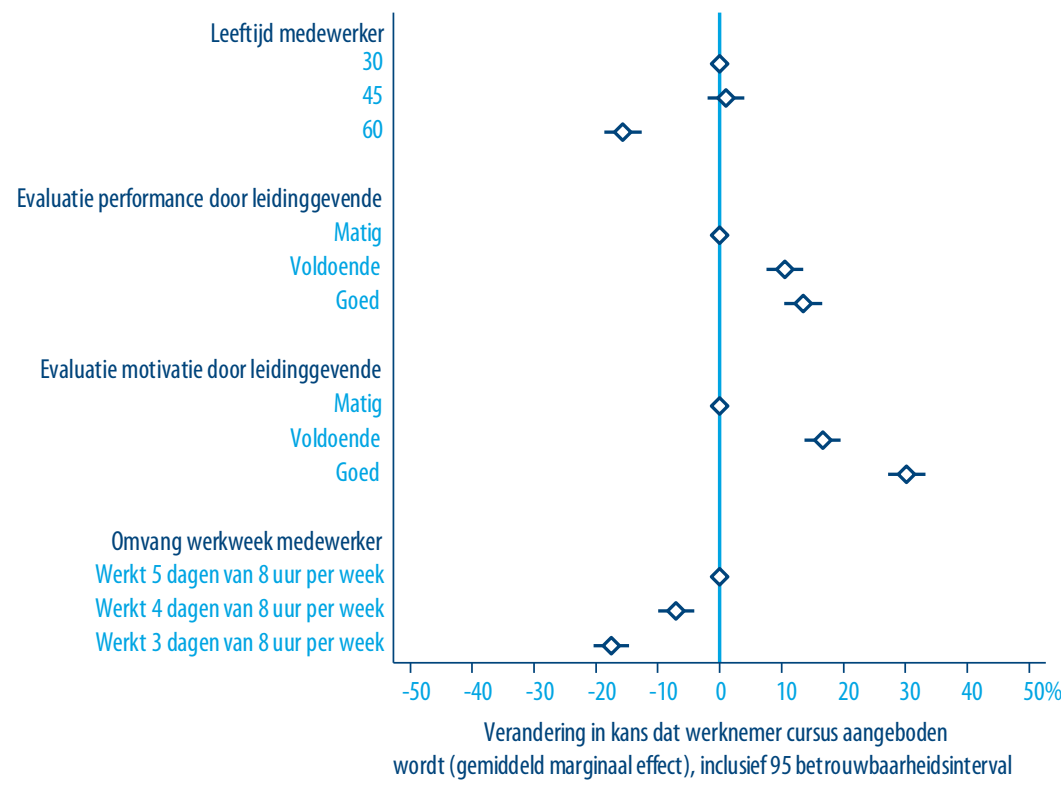

Bron: ROA Werkgeversenquête Scholingsbeleid, 2017

Noot: gebaseerd op een probit regressie met cluster-robuuste standaardfouten.

Werkgevers zijn minder bereid om in de scholing van 60-jarigen te investeren dan in die van 30 en 45 -jarigen. Er is echter geen verschil in bereidheid om in de scholing van 45 -jarigen of 30 -jarigen te investeren.
Figuur 5.1 laat zien dat werkgevers minder bereid zijn om in de scholing van 60-jarigen te investeren dan in de scholing van 30-jarigen en 45 -jarigen. Dit verschil is aanzienlijk en statistisch significant. Indien alle andere werknemerskenmerken gelijk zijn, dan zijn werkgevers 16 procentpunt minder bereid om in een 60-jarige te investeren dan in een 30 of 45-jarige. Daarentegen zijn werkgevers niet minder bereid om scholing aan te bieden aan 45-jarigen dan aan 30-jarigen. Dit betekent dat 55-plussers niet alleen minder scholing volgen vanwege hun geringere scholingsbereidheid (zie Hoofdstuk 4), maar ook omdat werkgevers minder bereid zijn om in hun scholing te investeren. Aanvullende analyses naar bedrijfsgrootte (hier niet getoond) laten geen significant verschil zien in de bereidheid om in 60-jarigen te investeren tussen grote en kleine bedrijven. 
Werkgevers investeren het meest in de scholing van medewerkers met een goede motivatie (+30\%-punt t.o.v. een matige motivatie) en performance (+13\%-punt t.o.v. een matige performance).
Figuur 5.1 laat ook zien dat zowel een goede perfomance als een goede motivatie van de werknemer de kans om een cursus aangeboden te krijgen vergroot. Werknemers waarvan de performance of motivatie als 'voldoende' worden beoordeeld hebben een

grotere kans om een cursus aangeboden te krijgen dan werknemers die op deze punten als 'matig' worden beoordeeld. Hetzelfde geldt overigens voor werknemers die als 'goed' worden beoordeeld ten opzicht van werknemers die als 'voldoende' worden beoordeeld. Een interessant verschil is wel dat het effect van de motivatie van de werknemer groter is dan het effect van diens performance. Zo heeft een medewerker met een goede performance 13 procentpunt meer kans om scholing aangeboden te krijgen dan iemand met een matige performance, terwijl een medewerker met een goede motivatie maar liefst 30 procentpunt meer kans heeft om scholing aangeboden te krijgen (ten opzicht van iemand die hier 'matig' scoort). Ook lijkt het erop dat het effect van iemands performance op de kans om scholing aangeboden te krijgen vooral betrekking heeft op het verschil tussen een matige en voldoende performance. Hier is het verschil namelijk 10 procentpunt, terwijl het verschil tussen 'voldoende' en goed slechts 3 procentpunt is. ${ }^{47}$ Vergelijkbare conclusies zijn eerder getrokken als het gaat om de werving door werkgevers (Humburg \& van der Velden, 2015). Bij de evaluatie van motivatie lijkt geen sprake van een dergelijke, duidelijke afvlakking: het verschil tussen een matige en voldoende motivatie is 17 procentpunt en het verschil tussen een voldoende en een goede motivatie is 14 procentpunt.

In deeltijd werken verkleint de kans om scholing aangeboden te krijgen aanzienlijk. Dit negatieve effect op de scholingskans is gelijk voor 30, 45 en 60-jarigen.
Tot slot blijkt uit Figuur 5.1 dat werkgevers minder bereid zijn om in de scholing van deeltijders te investeren. Ten opzichte van werkenden die voltijds werken zijn werkgevers 19 procentpunt minder bereid om te

investeren in werkenden die 32 uur per week werken (in dit geval meer specifiek 4 dagen van 8 uur per week). Dit is vergelijkbaar met het verschil in trainingsbereidheid tussen 30 of 45 jarigen en 60 jarigen. Voor werkenden die 24 uur per week werken loopt dit percentage zelfs op tot 48 procentpunt. Werkgevers zijn dus bijna de helft minder bereid om scholing aan te bieden aan werkenden die 3 dagen (van 8 uur) in plaats van 5 dagen (van 8 uur) per week werken. Een 6o-jarige werknemer die in deeltijd werkt heeft dus te maken met een dubbele achterstand in de werkgeversbereidheid om een training aan te bieden. Opvallend is wel dat ouderen die in deeltijd werken geen extra nadeel ondervinden van het feit dat zij in deeltijd werken dan jongeren. ledereen met een deeltijd-

47 Het verschil tussen 'voldoende' en 'goed' is net niet significant op 5\%-niveau, maar wel op 10\%-niveau $(p$-waarde $=0.0506)$. 
contract wordt geconfronteerd met dezelfde geringere bereidheid van de werkgever om scholing aan te bieden. ${ }^{48}$

\section{Afruil tussen werknemerskenmerken}

In deze paragraaf staat de vraag centraal in hoeverre 60-jarigen hun lagere kans om scholing aangeboden te krijgen kunnen compenseren door een goede performance of motivatie.

Figuur 5.2 geeft de afruil weer tussen leeftijd en de performance van een medewerker voor de kans om scholing aangeboden te krijgen.49 Op de horizontale as staan de verschillende leeftijden en op de verticale as de kans dat een werknemer een cursus aangeboden krijgt. De drie lijnen staan ieder voor een bepaalde waarde van de performance van de medewerker. De lijn voor een voldoende performance ligt altijd boven die van een matige performance en hetzelfde geldt voor de lijn met een goede performance ten opzicht van de lijn met een voldoende performance.

Uit het feit dat de lijnen in Figuur 5.2 elkaar niet kruisen kunnen we aflezen dat de kans om scholing aangeboden te krijgen voor alle leeftijden toeneemt als de performance van de medewerker beter is. 60-jarigen met een matige performance hebben de laagste kans om scholing aangeboden te krijgen, 30 en 45-jarigen met een goede performance hebben de hoogste kans om scholing aangeboden te krijgen. Uit de figuur blijkt ook dat er voor 60-jarigen (beperkte) mogelijkheden tot compensatie zijn: 60-jarigen met een goede performance hebben dezelfde kans om scholing aangeboden te krijgen als 30 of 45 -jarigen met een matige performance..$^{50} 60$-jarigen kunnen met een goede beoordeling van hun performance dus net in de buurt komen van een 30 of 45 -jarige werknemer met een matige performance. Op basis van alleen hun performance blijkt het voor 60-jarigen niet mogelijk om qua scholingskans in de buurt te komen van 30 en 45-jarigen waarvan de performance 'voldoende' is. Ten slotte laat de figuur zien dat de kans om scholing aangeboden te krijgen veel sterker stijgt als de performance van 'matig' naar 'voldoende' stijgt dan als de performance van 'voldoende' naar 'goed' stijgt. Het lijkt er dus op dat werkgevers voor alle leeftijdsgroepen vooral scholingsinvesteringen in matig presterende werknemers willen vermijden en in mindere mate selecteren op de best presenterende medewerkers.

48 Dit resultaat is niet af te lezen uit Figuur 5.1, maar is gebaseerd op een aanvullend interactiemodel.

49 De kenmerken van het vignetexperiment die níet in Figuur 5.2 zijn weergeven moeten voor het berekenen van de getoonde effecten wordt vastgeprikt op een vaste waarde. De hier weergeven effecten hebben betrekking op personen die voltijds werken en waarvan de motivatie door de leidinggevende als'voldoende' werd beoordeeld.

50 De vergelijking tussen 60-jarigen met een voldoende performance en 45 en 30-jarigen met een matige performance vallen nog in het nadeel van de 6o-jarigen uit: zij hebben in dat geval een scholingskans die nog net iets lager is dan een matig scorende 45 of 30 -jarige. 
FIGUUR 5.2 Kans dat werknemers van verschillende leeftijd scholing aangeboden krijgen afhankelijk van hun performance

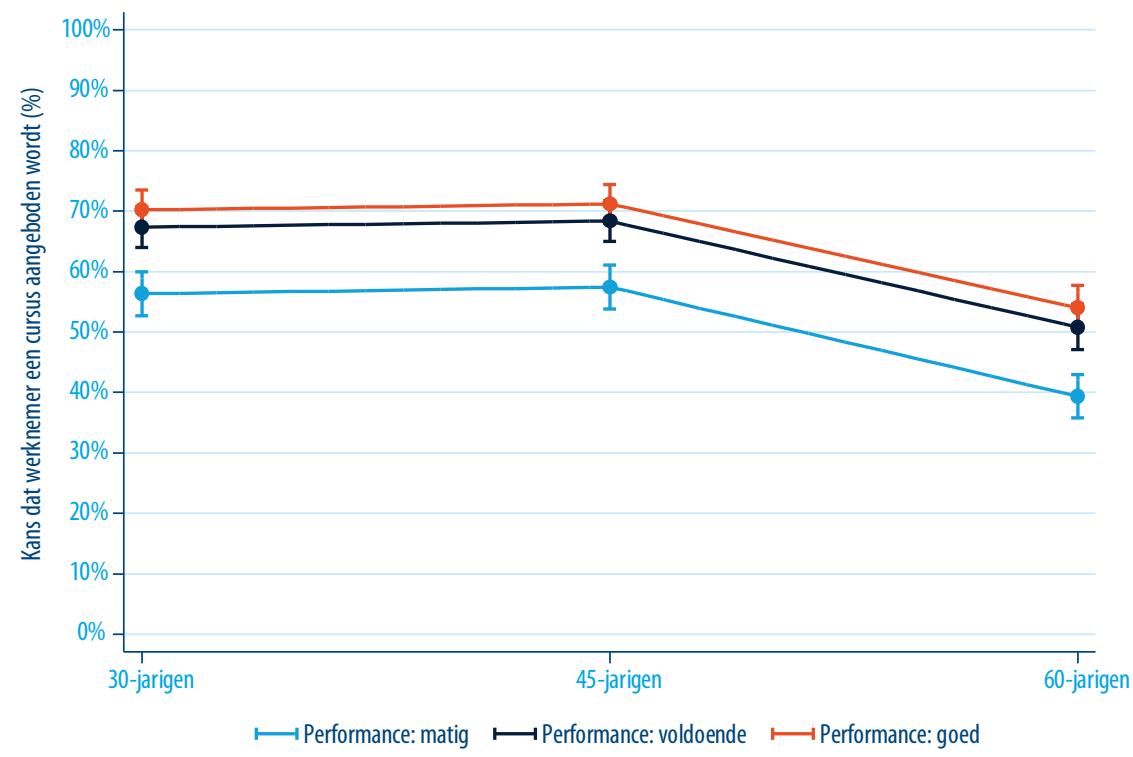

Bron: ROA Werkgeversenquête Scholingsbeleid, 2017

Noot: gebaseerd op probit regressie met cluster-robuuste standaardfouten.

6o-jarigen met een goede motivatie en performance kunnen hun lagere kans op scholing als gevolg van hun leeftijd (deels) compenseren doordat een goede motivatie en goede performance de kans op scholing juist verhogen. lemands motivatie speelt daarbij een belangrijkere dan iemands performance.
Naast de evaluatie van performance is in het vignetexperiment ook de evaluatie van de werkmotivatie van werknemers meegenomen. Figuur 5.3 toont de afruilmogelijkheden tussen leeftijd en de beoordeling met betrekking tot motivatie als bepalende kenmerken voor de kans om scholing aangeboden te krijgen. ${ }^{51}$ De figuur is op dezelfde manier opgezet als Figuur 5.2: de drie doorgetrokken lijnen representeren de verschillende niveaus van motivatie, zoals die is ingeschat door de direct leidinggevende. Ook hier blijkt dat 60-jarigen met een matige motivatie de laagste kans hebben om scholing aangeboden te krijgen en 30 en 45-jarigen met een goede beoordeling de hoogste kans. De figuur maakt meteen duidelijk dat er voor 60-jarige werkenden mogelijkheden tot compensatie zijn: werkgevers zijn significant vaker bereid om een goed gemotiveerde

51 Ook hier geldt dat de kenmerken van het vignet die níet de figuur zijn weergeven zijn vastgeprikt. De weergegeven effecten hebben daarom betrekking op personen die voltijds werken en waarvan de motivatie door de leidinggevende als 'voldoende' werd beoordeeld. 
60 jarige werknemer scholing aan te bieden dan de matig gemotiveerde 30 of 45 jarige werknemer, terwijl 60 jarigen met voldoende motivatie een vergelijkbare scholingskans hebben als 30 en 45 -jarigen met als matige motivatie. ${ }^{52} 60$-jarigen met een goede motivatie hebben ook een vergelijkbare kans op scholing als 30 en 45-jarigen met'voldoende' motivatie..$^{53}$ Een goede motivatie is dus wel degelijk een manier om de bereidheid van werkgevers om in 60-jarige werknemers te investeren te vergroten.

FIGUUR 5.3 Kans dat werknemers van verschillende leeftijd scholing aangeboden krijgen afhankelijk van hun motivatie

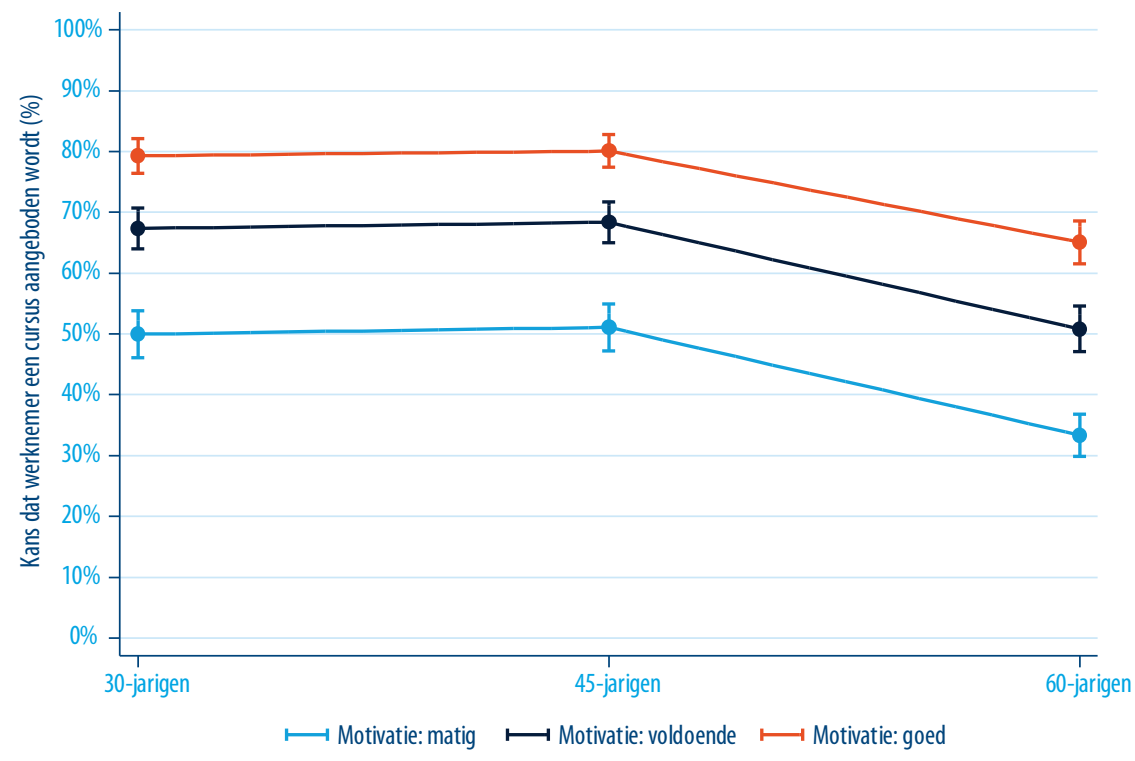

Bron: ROA Werkgeversenquête Scholingsbeleid, 2017

Noot: gebaseerd op probit regressie met cluster-robuuste standaardfouten.

Een 60-jarige met een goede performance en een goede motivatie heeft een vergelijkbare kans op scholing als een 30 of 40 jarige die op beide kenmerken voldoende scoort. kans op scholing hebben dan 30 en 45-jarigen die op beide variabelen 'matig' scoren. Ook blijkt dat deze 60-jarigen een gelijke scholingskans hebben als 30 en 45-jarigen met

52

De verschillen tussen 60-jarigen met voldoende motivatie en 45 en 30-jarigen met een matige motivatie zijn statistisch niet significant.

53 Ook hier geldt dat de verschillen tussen de groepen niet statistisch significant zijn. 
een voldoende performance en een matige motivatie. Dit geldt echter niet ten opzicht van 30 en 45-jarigen met een matige performance en voldoende motivatie. Ten opzichte van de 30 en 45-jarigen met een matige performance en voldoende motivatie hebben 6o-jarigen met een goede performance en motivatie echter wel een grotere scholingskans. Bij een goede score onder 60-jarigen op beide kenmerken is de scholingskans vergelijkbaar met 30 en 45 -jarigen die op beide kenmerken een 'voldoende' scoren.

\section{Stereotyperingen mogelijke verklaring voor lagere scholingsbereidheid werkgever}

Een verklaring voor de lagere bereidheid om in 60-jarigen te investeren kan mogelijk worden gevonden in het beeld of de stereotypes die werkgevers hebben van ouderen. Zo zou het bijvoorbeeld zo kunnen zijn dat werkgevers de motivatie en het vermogen om nieuwe dingen te leren onder oudere werknemers lager inschatten. Als gevolg hiervan zou het verwachte rendement van een scholingsinvestering in deze groep ook lager zijn waardoor een lagere bereidheid om in deze groep te investeren voor de hand ligt. In deze paragraaf onderzoeken we daarom of het beeld dat werkgevers hebben van de leermotivatie en het leervermogen van 60-jarigen een verklarende rol speelt in de lagere bereidheid om in deze groep te investeren. Werkgevers zijn gevraagd om op een vijfpuntschaal (van "zeer laag" tot en met "zeer hoog") aan te geven hoe hoog of laag zij $a$ ) het gemiddelde vermogen om nieuwe dingen te leren en b) de gemiddelde motivatie om nieuwe dingen te leren voor verschillende leeftijdsgroepen inschatten. Het gaat dus over de inschattingen van werkgevers met betrekking tot leeftijdsgroepen (stereotyperingen). Deze inschattingen staan los van de evaluaties met betrekking tot performance en werkmotivatie die in het keuze-experiment zélf zijn meegenomen. De evaluaties door leidinggevenden zoals die zijn meegenomen in het vignet hebben namelijk betrekking op individuen in plaats van op groepen en hebben betrekking op de werkmotivatie en de algehele performance van deze werknemers en niet direct op het vermogen en de motivatie om nieuwe dingen te leren.

Figuur 5.4 laat zien dat er duidelijke verschillen zijn tussen de inschattingen die werkgevers hebben van het leervermogen en de leermotivatie van 30, 45 en 60-jarigen. Voor beide variabelen geldt dat werkgevers hun werknemers gemiddeld lager inschatten naarmate deze werknemers ouder zijn. 
FIGUUR 5.4 Inschatting van gemiddelde leermotivatie en leervermogen door werkgevers, naar leeftijd van de werknemer

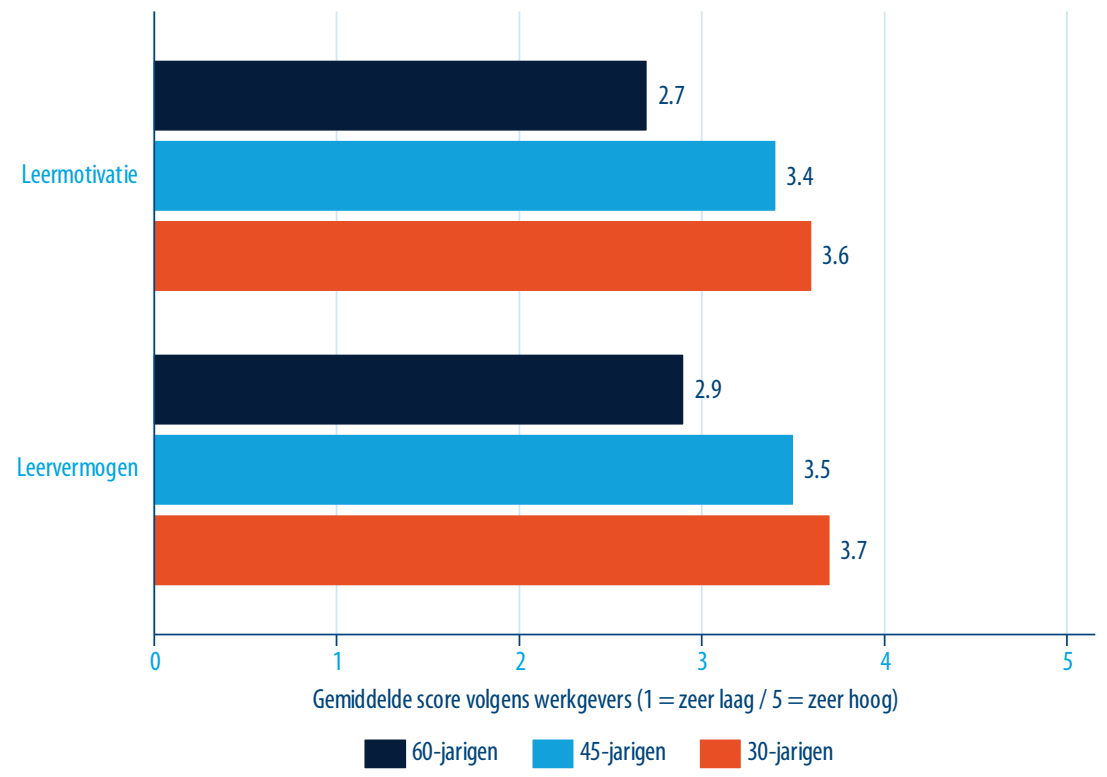

Bron: ROA Werkgeversenquête Scholingsbeleid, 2017

Noot: voor beide variabelen zijn alle onderlinge verschillen naar leeftijd statistisch significant.

Werkgevers schatten de gemiddelde leermotivatie en het gemiddelde leervermogen van oudere werknemers lager in. Dit beeld van oudere werknemers vormt een gedeeltelijke verklaring voor hun lagere bereidheid om in de scholing van 6o-jarigen te investeren.
De verschillen in het gepercipieerde leervermogen en de gepercipieerde leermotivatie blijken inderdaad een rol te spelen bij het verklaren van het verschil in de scholingsbereidheid van werkgevers voor werknemers van verschillende leeftijden. Het effect hiervan is te zien in Figuur 5.5. De percentages in deze figuur hebben betrekking op

voltijdswerkende 60-jarigen met zowel een voldoende performance als motivatie. Uit de figuur blijkt dat deze werkenden een kans van 47 procent hebben om de scholing aangeboden te krijgen als hun werkgever de leermotivatie en het leervermogen van 60-jarige werkenden als relatief laag beoordelen. ${ }^{54}$ Als de leermotivatie of het leervermogen van 60-jarigen door de werkgever als hoog wordt ingeschat, dan stijgt de kans om de scholing aangeboden te krijgen naar ongeveer 55 procent en bij werkgevers die 60 -jarigen op beide variabelen relatief hoog inschatten stijgt dit percentage naar 62 procent. Dit suggereert dat de relatief lage inschatting van werkgevers met betrekking

54 Relatief laag beoordelen wil zeggen dat zij 6o-jarigen een score gaven van 1-3 op de hierboven beschreven enquêtevragen. 
tot de leermotivatie en het leervermogen van 60-jarigen deels verantwoordelijk is voor hun lagere bereidheid om in de scholing 60-jarigen te investeren.

FIGUUR 5.5 Kans dat een 60-jarige werknemer scholing aangeboden krijgt, naar inschatting van de werkgever over het leervermogen en leermotivatie van laagopgeleiden.

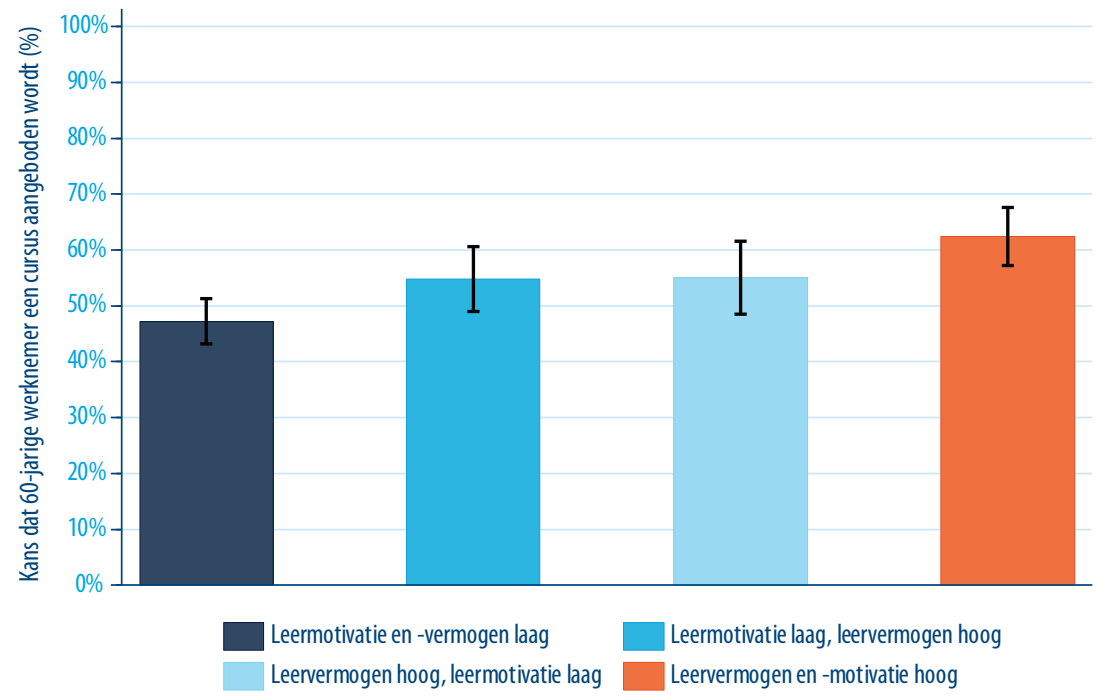

Bron: ROA Werkgeversenquête Scholingsbeleid, 2017.

Noot: gebaseerd op probit regressie met cluster-robuuste standaardfouten en interactie-effecten tussen respectievelijk de leeftijd van de werkende en de inschatting van leermotivatie en de leeftijd en de inschatting van het leervermogen.

\subsection{Bereidheid om in laagopgeleiden te investeren}

In het tweede vignetexperiment dat is opgenomen in de ROA Werkgeversenquête Scholingsbeleid 2017 staat de bereidheid van werkgevers om scholing aan te bieden aan werknemers met verschillende opleidingsniveaus centraal. De vraag die we met dit tweede vignet proberen te beantwoorden is in welke mate werkgevers bereid zijn te investeren in de scholing van laagopgeleide medewerkers in vergelijking met hoger opgeleide medewerkers.

\section{Opzet vignetexperiment}

In dit tweede vignetexperiment werden werkgevers gevraagd om bij het aanbieden van een cursus een keuze te maken tussen twee werknemers die van elkaar verschillen op een viertal gerandomiseerde kenmerken: hun opleidingsniveau, het gebied waarop zij scholing betrekking op heeft, hun bereidheid zich in eigen tijd te scholen, en hun 
bereidheid tot het leveren van een eigen financiële bijdrage voor de scholing. De specifieke context van dit vignetexperiment werd als volgt toegelicht:55

\author{
"Wij vragen u [...] 3 keer een keuze te maken tussen 2 medewerkers voor het volgen van scholing \\ die 8 uur duurt en $€ 1.000$,- kost. De medewerkers verschillen van elkaar op de volgende kenmerken: \\ - Het gebied waarop zij scholing willen volgen \\ - Hun opleidingsniveau \\ - Hun bereidheid zich in eigen tijd te scholen \\ - Hun bereidheid tot het leveren van een eigen financiële bijdrage voor de scholing"
}

Tabel 5.2 geeft een overzicht van de vier kenmerken en hun onderliggende waardes waarop de medewerkers van elkaar verschillen. Bij deze kenmerken is geprobeerd zoveel mogelijk een link te leggen met het werknemersvignet dat besproken is in Hoofdstuk 4.

Voor het kenmerk 'opleidingsniveau werknemer' is gekozen voor drie specifieke opleidingsniveaus, te weten vmbo, mbo en hbo. Deze drie opleidingsniveaus representeren respectievelijk de laagopgeleiden, middelbaar opgeleiden en hoogopgeleiden. Net als bij het leeftijdenvignet is dit gedaan om het realisme van het vignet te vergoten. Bij een specifiek opleidingsniveau kunnen werkgevers zich namelijk gemakkelijker een beeld vormen. De overige drie kenmerken die naast het opleidingsniveau van de werkende worden meegenomen zijn hoofdzakelijk gebaseerd op het werknemersvignet (Hoofdstuk 4). Uit Hoofdstuk 4 bleek dat laagopgeleide werknemers minder geneigd zijn een cursus te volgen als er van hen een eigen bijdrage in termen van tijd of geld verwacht wordt.

TABEL 5.2 Kenmerken en onderliggende waardes in het vignetexperiment met betrekking tot het opleidingsniveau van medewerkers

\begin{tabular}{|c|c|}
\hline Kenmerk & Opties \\
\hline Opleidingsniveau werknemer & $\begin{array}{l}\text { 1. } \mathrm{Vmbo} \\
\text { 2. } \mathrm{Mbo} \\
\text { 3. } \mathrm{Hbo}\end{array}$ \\
\hline Gebied waarop de werknemer scholing wil volgen & $\begin{array}{l}\text { 1. Vaktechnische kennis en vaardigheden } \\
\text { 2. Sociale en communicatieve vaardigheden } \\
\text { 3. Loopbaanoriëntatie en coaching }\end{array}$ \\
\hline Bereidheid werknemer om zich in eigen tijd te scholen & $\begin{array}{l}\text { 1. } 0 \text { uur in eigen tijd } \\
\text { 2. } 4 \text { uur in eigen tijd } \\
\text { 3. } 8 \text { uur in eigen tijd }\end{array}$ \\
\hline $\begin{array}{l}\text { Bereidheid van werknemer tot het leveren van een eigen financiële } \\
\text { bijdrage voor de scholing }\end{array}$ & $\begin{array}{l}\text { 1. } 0 \text { euro } \\
\text { 2. } 100 \text { euro } \\
\text { 3. } 200 \text { euro }\end{array}$ \\
\hline
\end{tabular}

55 De situatieschets bij dit vignet wijkt dus enigszins af van die bij het leeftijdenvignet. Zo duurt de cursus hier 8 uur in plaats van 16 uur en kostte de cursus $€ 1000$,- in plaats van $€ 2000$,-. Ook heeft de scholing in dit vignetexperiment niet meer louter betrekking op vaktechnische kennis en vaardigheden, maar varieert het type scholing in het experiment. Deze afwijkende context van dit vignet vergemakkelijkt een directe vergelijking met het werknemersvignet uit Hoofdstuk 4 (hier betrof het ook een cursus van 8 uur die $€ 1000,-$ kost en varieerde het type cursus). 


\section{Bereidheid tot investeren naar werknemerskenmerken}

In Figuur 5.6 is voor elk werknemerskenmerk aangegeven in hoeverre een werknemer met dit kenmerk een grotere of juist kleinere kans heeft om scholing aangeboden te krijgen dan een medewerker met de referentiewaarde op dat kenmerk.

De resultaten van het vignetexperiment in Figuur 5.6 geven geen indicatie dat werkgevers minder bereid zijn om in laagopgeleiden te investeren dan in hoogopgeleiden.56 Zoals in Figuur 5.6 kan worden gezien liggen de geschatte effecten voor laagopgeleiden (vmbo'ers) en hoogopgeleiden (hbo'ers) heel dicht bij elkaar. ${ }^{57}$ Wel is er sprake van een voorkeur voor het investeren in de scholing van middelbaar opgeleiden. De kans dat zij de scholing kunnen volgen is 5 procentpunt hoger dan voor de laagopgeleiden. Het feit dat werkgevers in ons vignetexperiment dus niet minder bereid zijn om in laagopgeleiden dan in hoogopgeleiden te investeren suggereert dat de lagere trainingsparticipatie die in Hoofdstuk 2 is waargenomen voornamelijk het gevolg is van een lagere trainingsbereidheid van de laagopgeleide zelf en niet zozeer van een lagere bereidheid vanuit de werkgever (zie ook Fouarge et al., 2013). Deze suggestie wordt ook ondersteund door de bevinding in Hoofdstuk 4 dat laagopgeleiden minder bereid blijken om de door hen binnen het vignet gekozen cursus ook daadwerkelijk te gaan volgen. Aanvullende analyses naar bedrijfsgrootte (hier niet getoond) laten geen significant verschil zien in de bereidheid om in laagopgeleiden te investeren tussen grote en kleine bedrijven. minder groot dan de kans dat een lager opgeleide de scholing krijgt aangeboden, maar dit verschil blijkt niet statistisch significant (zoals ook kan worden gezien aan het feit dat het 95\%-betrouwbaarheidsinterval de verticale blauwe lijn in het midden van de figuur doorkruist). 
FIGUUR 5.6 Effect van verschillende werknemerskenmerken op de kans om scholing aangeboden te krijgen

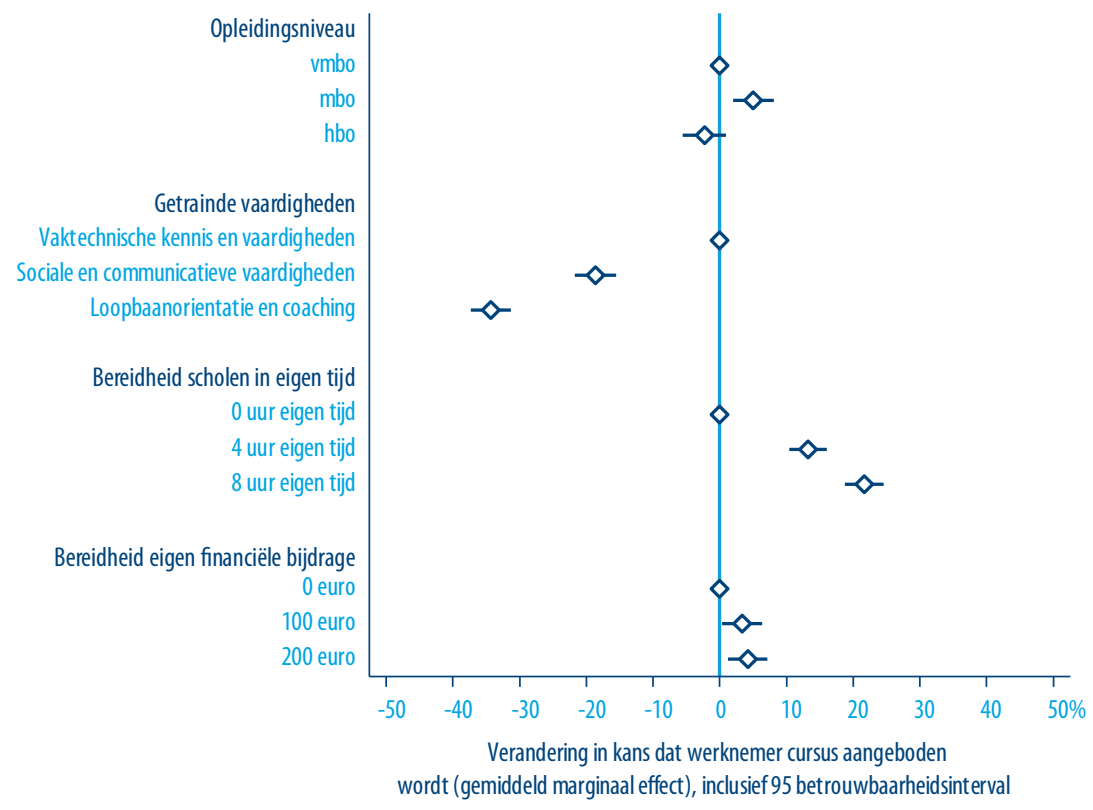

Bron: ROA Werkgeversenquête Scholingsbeleid, 2017

Noot: gebaseerd op probit regressie met cluster-robuuste standaardfouten.

Werknemers die bereid zijn een eigen bijdrage te leveren in termen van tijd of geld hebben een grotere kans om scholing te ontvangen. Het positieve effect van een eigen bijdrage vlakt snel af naarmate de eigen bijdrage hoger is, terwijl dat niet geldt voor een eigen bijdrage in termen van tijd.
Naast opleidingsniveau kan ook naar de overige kenmerken die in dit vignet zijn meegenomen gekeken worden. Werkgevers blijken werknemers die bereid zijn om zelf een bijdrage in termen van geld of eigen tijd te leveren eerder scholing aan te bieden dan werknemers die niet bereid zijn dat te doen. Interessant om hierbij op te merken is dat er in het geval van een eigen bijdrage in termen van geld duidelijk sprake is van een afnemend effect: de eerste 100 euro die werkenden bereid zijn zelf bij te dragen vergroot de kans op training met iets meer dan 3 procentpunt, terwijl een verdubbeling van de eigen bijdrage naar 200 euro de kans om de scholing te mogen volgen met minder dan 1 extra procentpunt vergroot. Dit suggereert dat werkgevers een eigen bijdrage zien als een extra commitment van de werknemer om zich voor de scholing in te zetten. 
De bereidheid om 4 uur zelf bij te dragen vergroot de kans om gekozen te worden met 13 procentpunt ten opzichte van iemand die de scholing alleen wil volgen als deze volledig onder werktijd gevolgd kan worden. Werknemers die bereid zijn de volledige scholing van 8 uur in eigen tijd te volgen hebben zelfs een 22 procentpunt grotere kans om de scholing te volgen dan werknemers die de scholing alleen willen volgen als dat volledig onder werktijd kan.

In Hoofdstuk 4 bleek echter dat een eigen financiële bijdrage het participeren in scholing voor de laagopgeleiden zelf minder aantrekkelijk maakt..58 Ook eigen bijdragen in termen van tijd bleken voor hen een signifcant negatieve impact te hebben op hun scholingsbereidheid. ${ }^{59}$ Werkgevers blijken overigens vooral een eigen bijdrage in termen van tijd te waarderen, terwijl werknemers vooral een afkeer hebben van een eigen bijdrage in termen van geld. Dit suggereert dat werkgevers en werknemers elkaar dus vooral zouden kunnen vinden bij de eis dat de scholing in werktijd gevolgd moet kunnen worden en minder goed bij een vereiste eigen financiële bijdrage.

Werkgevers bieden het liefst scholing aan gericht op vaktechnische kennis en vaardigheden. Het trainen van sociale en communicatie vaardigheden is onder werkgevers minder populair. Dit geldt nog sterker voor scholing op het gebied van loopbaanoriëntatie en coaching.
Tot slot blijkt uit Figuur 5.6 dat werkgevers eerder bereid zijn om in scholing te investeren als de medewerker een training wil volgen op het gebied van vaktechnische kennis en vaardigheden. Scholing gericht op sociale en communicatieve vaardigheden is beduidend minder populair: medewerkers die scholing op dit terrein willen volgen maken gemiddeld 19 procentpunt minder kans om de scholing door hun werkgever aangeboden te krijgen dan medewerkers die hun vaktechnische kennis en vaardigheden willen trainen. Loopbaanoriëntatie en coaching blijkt onder werkgevers echter nog minder prioriteit te hebben. De kans dat werkgevers werkenden die scholing op dit terrein willen volgen daadwerkelijk de scholing willen laten volgen is 34 procentpunt lager dan de kans dat zij iemand de mogelijkheid bieden om door een training zijn of haar vaktechnische kennis en vaardigheden te verbeteren.

De resultaten wat betreft het type cursus (dat wil zeggen wat betreft de vaardigheden die getraind worden) zijn grotendeels vergelijkbaar met de resultaten uit het werknemersvignet in Hoofdstuk 4. Hier hadden de cursussen gericht op vaktechnische competenties en vaardigheden voor laagopgeleiden (en de meeste andere onderscheiden groepen) ook de hoogste prioriteit, terwijl het trainen van sociale en communicatie vaardigheden en loopbaanoriëntatie en coaching onder laagopgeleiden een stuk minder populair bleken.

58 Dit gold overigens ook voor de andere categorieën werknemers, met uitzonderingen van werknemers met een tijdelijk contract. 


\section{Beeld van werkgevers met betrekking tot de leermotivatie en het leervermogen van laagopgeleiden}

In deze paragraaf brengen we in kaart welk beeld werkgevers hebben van het leervermogen en de leermotivatie onder laagopgeleiden, middelbaar opgeleiden en hoogopgeleiden. Daarnaast onderzoeken we in hoeverre de bereidheid om in laagopgeleiden te investeren afhankelijk is van beeld dat werkgevers hebben van de leermotivatie en het leervermogen van deze groep.

Allereerst kijken we weer naar de vraag hoe werkgevers de leermotivatie en het leervermogen van laag-, middelbaar en hoogopgeleide werkenden inschatten. In Figuur 5.7 zijn de percepties van werkgevers te zien voor de drie onderscheiden opleidingsniveaus. Zowel de inschatting van de leermotivatie als de inschatting van het leervermogen is het laagst voor laagopgeleiden en het hoogst voor hoogopgeleiden. De verschillen zijn omvangrijk en statistisch significant, al zijn de verschillen wel iets minder groot dan de verschillen tussen de verschillende leeftijdsgroepen in de vorige paragraaf.

FIGUUR 5.7 Inschatting van leermotivatie en leervermogen door werkgevers, naar het opleidingsniveau van de medewerkers

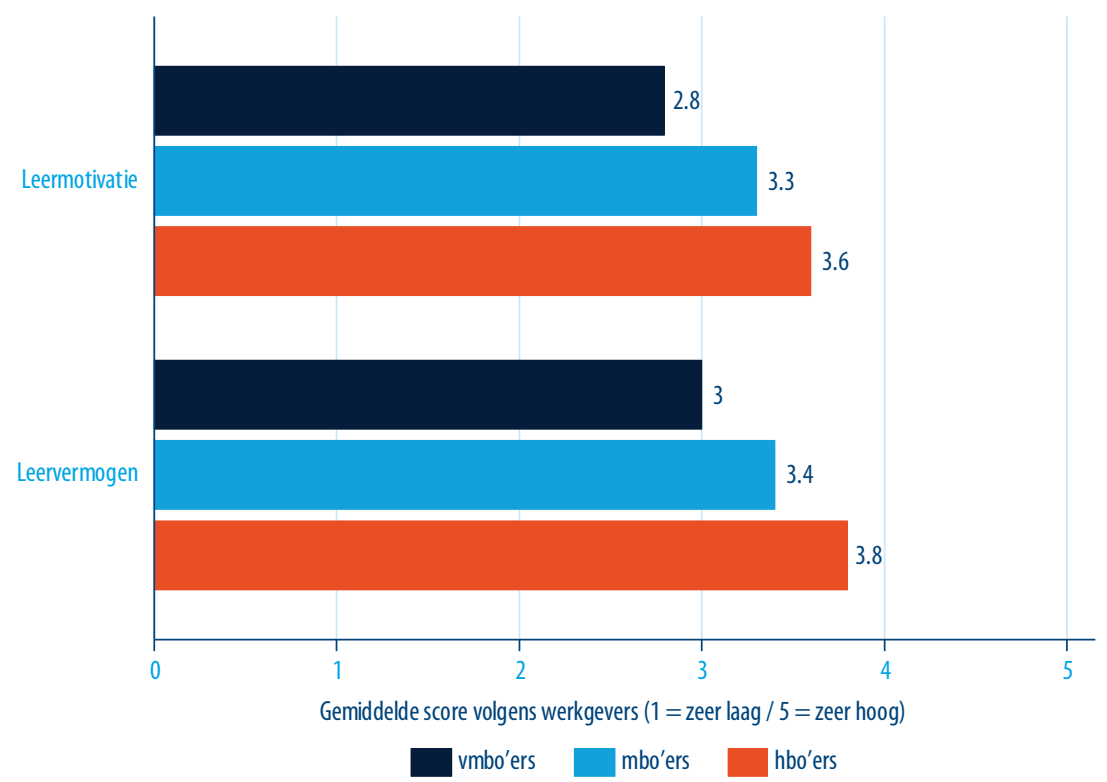

Bron: ROA Werkgeversenquête Scholingsbeleid, 2017

Noot: voor beide variabelen geldt dat alle onderlinge verschillen naar opleidingsniveau statistisch significant zijn. 
De bereidheid om in laagopgeleiden te investeren blijkt nauwelijks afhankelijk van de werkgeverpercepties met betrekking tot het leervermogen en de leermotivatie van deze groep.
Ondanks de relatief grote verschillen in de inschatting van werkgevers van de leermotivatie en het leervermogen van de werkenden uit verschillende opleidingsniveaus blijkt dat werkgevers die verschillen in deze percepties niet verschillen in hun keuzes bij het aanbieden van cursussen. Figuur 5.8 laat zien dat de kans dat een laagopgeleide medewerker scholing aangeboden krijgt nauwelijks verschilt tussen werkgevers die een relatief negatief beeld hebben van de leermotivatie en het leervermogen van laagopgeleiden en werkgevers die juist een relatief hoge inschatting van het leervermogen en de leermotivatie van deze groep hebben. ${ }^{60}$ Het verschil tussen werkgevers die zowel de leermotivatie als het leervermogen relatief laag inschatten versus werkgevers die beide relatief hoog inschatten is 5 procentpunt en is slechts significant op 10 procent-niveau. De overige verschillen zijn statistisch niet significant.

FIGUUR 5.8 Kans dat een vmbo werknemer scholing aangeboden krijgt, naar de inschatting van werkgever van het leervermogen en de leermotivatie van laagopgeleiden.

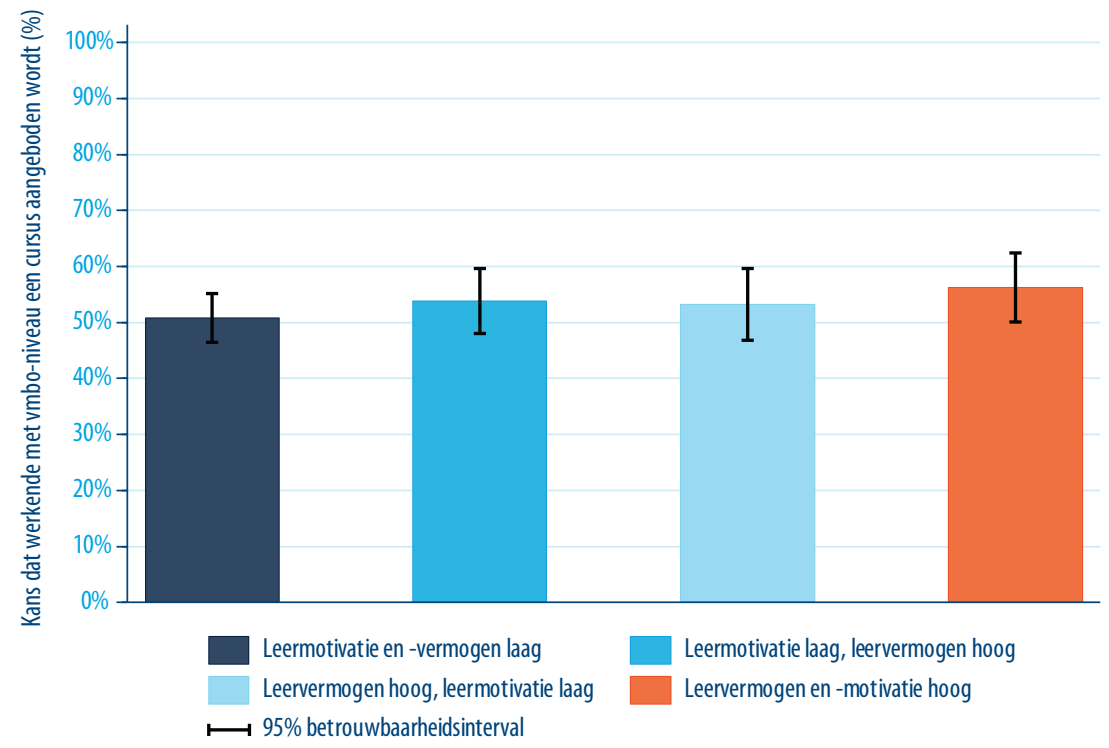

Bron: ROA Werkgeversenquête Scholingsbeleid, 2017

Noot: gebaseerd op probit regressie met cluster-robuuste standaardfouten en interactie-effecten tussen respectievelijk het opleidingsniveau en de inschatting van de leermotivatie en opleidingsniveau en de inschatting van het leervermogen.

60 De percentages in Figuur 5.8 zijn gebaseerd op een vmbo'er die een vaktechnische cursus wil volgen en niet bereid is om een eigen bijdrage in termen van geld of tijd te leveren. 


\title{
5.3 Bereidheid om te investeren in werkenden met een tijdelijk contract
}

In het derde vignetexperiment dat is opgenomen in de ROA Werkgeversenquête Scholingsbeleid 2017, proberen we de vraag te beantwoorden of werkgevers minder bereid zijn om in de scholing van een medewerker met een tijdelijk contract te investeren dan in de scholing van een medewerker met een vast contract. Ook hier maken we een onderscheid tussen tijdelijke contracten mét uitzicht op een vast contract en tijdelijke contracten zónder uitzicht op een vast contract.

De analyses laten zien dat werkenden met een tijdelijk contract in de vignetstudie minder kans maken om de scholing te kunnen volgen. Dit wijst erop dat de lagere trainingsparticipatie van werkenden met een tijdelijk contract die naar voren kwam in de eerdere hoofdstukken eerder het gevolg is van een lagere bereidheid vanuit de werkgever om in deze groep te investeren dan dat deze lagere trainingsparticipatie te wijten is aan de werknemer zelf. In Hoofdstuk 4 werd namelijk duidelijk dat werknemers met een tijdelijk contract zonder uitzicht op vast, in tegenstelling tot alle andere onderscheiden groepen werknemers, niet afschrikken van een eigen bijdrage in termen van geld en tijd. Daarnaast is er voor de werknemers met een tijdelijk contract zonder uitzicht op vast geen correlatie tussen hun bereidheid om de binnen het vignet uitgekozen cursus daadwerkelijk te volgen en hun feitelijke trainingsdeelname. Zo blijkt uit Hoofdstuk 2 dat zij een fors lagere trainingsparticipatie hebben dan werkenden met een vaste aanstelling, terwijl zij in de vignetstudie in Hoofdstuk 4 veel vaker aangeven een cursus daadwerkelijk te willen volgen dan werknemers met een vast contract. ${ }^{61}$

\section{Opzet vignetexperiment contracttypes}

Ook in dit derde vignetexperiment wordt aan de werkgevers gevraagd om bij het aanbieden van scholing drie keer een keuze te maken tussen twee werknemers die van elkaar verschillen op een viertal kenmerken: het type arbeidscontract, de bruikbaarheid van de scholing binnen en buiten de organisatie, de bereidheid tot het leveren van een eigen financiële bijdrage voor de scholing, en een eventuele terugbetalingsverplichting van de scholingskosten door de medewerker. ${ }^{62}$ De specifieke context die bij dit vignetexperiment werd gegeven luidde als volgt:

\author{
"Wij vragen u [...] 3 keer een keuze te maken tussen 2 medewerkers voor het volgen van scholing \\ (cursus of training) gericht op vaktechnische kennis en vaardigheden die 16 uur duurt en $€ 2.000,-$ kost. \\ De medewerkers verschillen deze keer op de volgende kenmerken: \\ - Het type arbeidscontract \\ - De bruikbaarheid van de scholing binnen en buiten uw organisatie
}

61 Onder geen enkele door ons onderscheiden groep met een kwetsbare arbeidsmarktpositie is de trainingsparticipatie zo laag als onder werkenden met tijdelijk contract zonder uitzicht op vast (Figuur 2.1), terwijl tegelijkertijd onder geen enkele groep het percentage werkenden dat alle gekozen cursussen uit ons werknemersvignet daadwerkelijk wil gaan volgen zo hoog is (Figuur 4.3).

62 De situatieschets bij dit vignet was vrijwel identiek aan die bij het leeftijdenvignet. Als een werkgever een bepaalde categorie werknemers niet in dienst heeft (bijvoorbeeld tijdelijke werknemers zonder zicht op een vast contract), werd hen gevraagd zich voor te stellen dat zij deze toch in dienst hebben. 
- Hun bereidheid tot het leveren van een eigen financiële bijdrage voor de scholing

- De terugbetalingsverplichting van de scholingskosten door de medewerker"

Tabel 5.3 geeft een overzicht van de vier kenmerken en hun onderliggende waardes waarop de werknemers in dit vignetexperiment van elkaar verschillen. De bruikbaarheid van de scholing binnen en buiten de organisatie is meegenomen, omdat het voor de verdere loopbaan van werkenden met een tijdelijk contract zonder uitzicht op een vaste aanstelling noodzakelijk is dat de getrainde kennis en vaardigheden ook bij potentiële nieuwe werkgevers kunnen worden ingezet. Dit sluit aan bij het in de menselijk-kapitaal literatuur gemaakte onderscheid tussen bedrijfsspecifieke kennis en vaardigheden en meer algemene vaardigheden anderzijds (Becker, 1964). De bereidheid tot het leveren van een eigen financiële bijdrage en de terugbetalingsverplichting van de gemaakte scholingskosten bij vroegtijdig vertrek zijn meegenomen als potentiële compenserende factoren waarmee een eventuele lagere bereidheid om in werkenden met een tijdelijk contract te investeren mogelijk gecompenseerd zou kunnen worden.

TABEL 5.3 Kenmerken en onderliggende waardes in het vignetexperiment met betrekking tot de aard van het dienstverband van medewerkers

\begin{tabular}{|c|c|}
\hline Kenmerk & Opties \\
\hline Het type arbeidscontract & $\begin{array}{l}\text { 1. Vast contract } \\
\text { 2. Tijdelijk contract voor } 2 \text { jaar mét uitzicht op vast } \\
\text { 3. Tijdelijk contract voor } 2 \text { jaar zónder uitzicht op vast }\end{array}$ \\
\hline De bruikbaarheid van de scholing binnen en buiten uw organisatie & $\begin{array}{l}\text { 1. Uitsluitend in uw organisatie } \\
\text { 2. In uw organisatie en organisaties binnen uw bedrifftak } \\
\text { 3. In uw organisatie en organisaties binnen en buiten uw } \\
\text { bedrijfstak }\end{array}$ \\
\hline Bereidheid tot het leveren van een eigen financiële bijdrage & $\begin{array}{l}\text { 1. } 0 \text { euro } \\
\text { 2. } 200 \text { euro } \\
3.400 \text { euro }\end{array}$ \\
\hline $\begin{array}{l}\text { Terugbetalingsverplichting van de scholingskosten door de } \\
\text { medewerker }\end{array}$ & $\begin{array}{l}\text { 1. Geen terugbetaling } \\
\text { 2. Medewerker betaalt } 50 \% \text { terug bij vrijwillig verlaten } \\
\text { bedrijf binnen } 1 \text { jaar } \\
\text { 3. Medewerker betaalt } 100 \% \text { terug bij vrijwillig verlaten } \\
\text { bedrijf binnen } 1 \text { jaar }\end{array}$ \\
\hline
\end{tabular}

\section{Bereidheid tot investeren naar werknemerskenmerken}

Werkgevers zijn fors minder bereid om in de scholing van werknemers met een tijdelijke aanstelling te investeren. Werknemers met een tijdelijk contract zonder uitzicht op een vaste aanstelling ondervinden hiervan veruit het grootste nadeel.
In Figuur 5.9 is voor elk werknemerskenmerk aangegeven in hoeverre een werknemer met dit kenmerk een grotere dan wel kleinere kans heeft om scholing aangeboden te krijgen dan een medewerker met de referen- 
tiewaarde op dat kenmerk. Het laat duidelijk zien dat werkgevers minder bereid zijn om te investeren in de scholing van werknemers die in tijdelijke dienst zijn. Werkenden met een tijdelijk contract mét uitzicht op vast hebben ongeveer 10 procentpunt minder kans om scholing aangeboden te krijgen dan werkenden met een vaste aanstelling. Werkenden met een tijdelijk contract zónder uitzicht op vast hebben een nog groter nadeel: voor hen is de kans op scholing in het vignetexperiment maar liefst 37 procentpunt kleiner dan voor werkenden met een vaste aanstelling. Opvallend is dus dat de tijdelijke contracten mét uitzicht qua kans op scholing meer op de vaste contracten lijken dan dat op de tijdelijke contracten zónder uitzicht lijken. Dit is in overeenstemming met de bevindingen uit Hoofdstuk 2 en de bestaande literatuur over trainingsgedrag (Ferreira et al., 2017).

FIGUUR 5.9 Effect van verschillende werknemerskenmerken op de kans om scholing aangeboden te krijgen

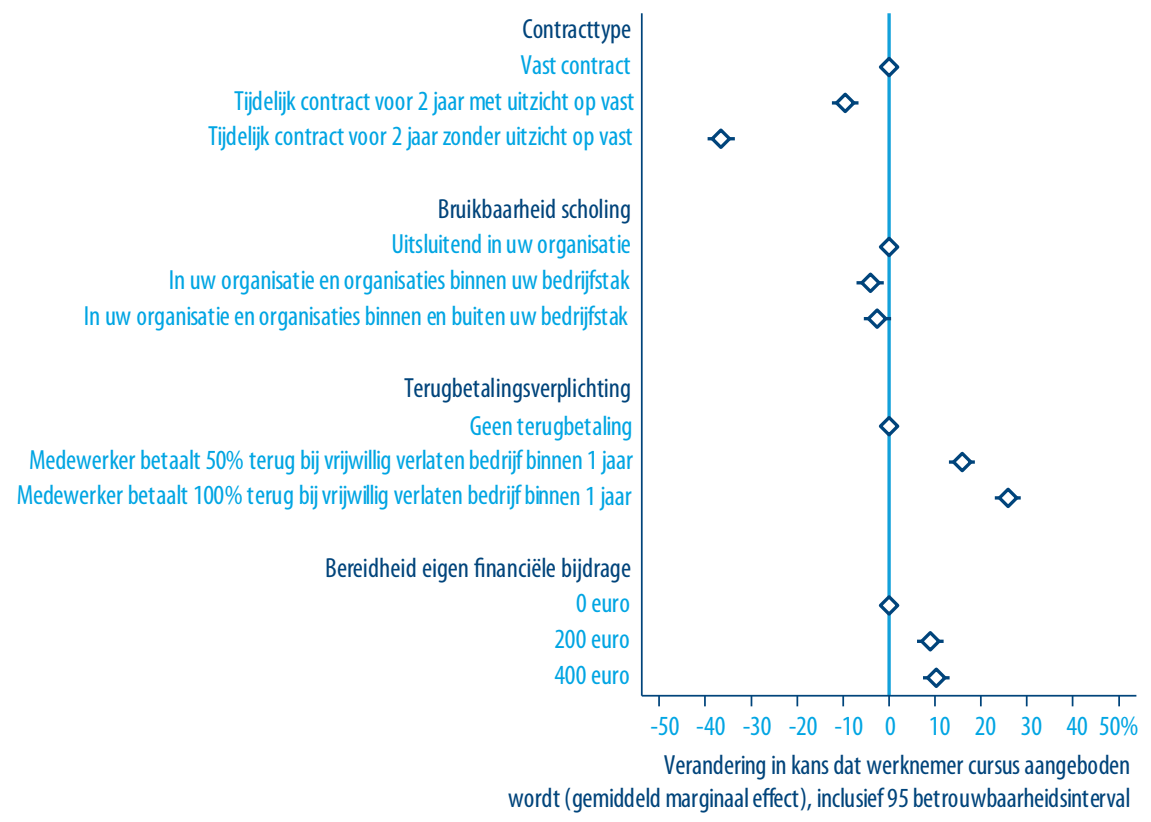

Bron: ROA Werkgeversenquête Scholingsbeleid, 2017

Noot: gebaseerd op probit regressie met cluster-robuuste standaardfouten.

Werkgevers zijn minder bereid om in scholing te investeren die ook buiten de eigen organisatie inzetbaar is. Dit is vooral nadelig voor werkenden met een tijdelijke aanstelling aangezien zij eerder gedwongen zullen zijn op zoek te gaan naar een andere baan.
Uit Figuur 5.9 blijkt ook dat werkgevers minder bereid zijn te investeren in scholing die ook binnen dezelfde bedrijfstak of zelfs buiten de eigen bedrijfstak inzetbaar is. Hoewel deze effecten met 4 en 3 procent- 
punt relatief beperkt blijven, is dit wel extra nadelig voor werkenden met een tijdelijk contract zonder uitzicht op vast werk, aangezien juist voor deze groep het investeren in kennis en vaardigheden die ook bruikbaar zijn buiten de huidige organisatie vanwege de tijdelijke aard van het contract van belang is. $\mathrm{Na}$ het verlopen van hun huidige contract zullen deze werknemers in de meeste gevallen immers op zoek moeten naar een andere werkgever.

Grotere organisaties zijn over het algemeen vaker bereid om in breed inzetbare scholing te investeren. Dit geldt echter alleen voor investeringen in vaste medewerkers of tijdelijke medewerkers met uitzicht op een vaste aanstelling en niét voor tijdelijke werknemers zonder uitzicht op een vaste aanstelling.

Aanvullende analyses naar bedrijfsgrootte (hier niet getoond) lieten geen significant verschil zien in de bereidheid om in tijdelijke werknemers te investeren, maar wel in de algemene bereidheid om in breed inzetbare scholing te investeren. Grotere organisaties blijken eerder bereid om in breed inzetbare scholing te investeren dan kleinere organisaties. Dit geldt zowel voor training die inzetbaar is binnen de eigen bedrijfstak, maar (vooral) ook voor training die zowel binnen als buiten de eigen bedrijfstak inzetbaar is. Een uitsplitsing naar contracttype laat echter zien dat dit positieve alleen statistisch significant is voor vaste werknemers en werknemers met een tijdelijk contract zónder uitzicht op vast, maar niet voor tijdelijke medewerkers zonder uitzicht op een vaste aanstelling.

Een terugbetalingsverplichting van de gemaakte scholingskosten bij vroegtijdig vertrek en een eigen financiële bijdrage vanuit de werknemer verhogen de kans op scholing.
Een terugbetalingsverplichting en een eigen financiële bijdrage blijken de kans te verhogen dat een werkgever een cursus aanbiedt. Bij beide kenmerken blijkt er echter sprake te zijn van een afnemend effect: een eigen bijdrage van de werknemer van 200

euro verhoogt de kans op scholing bijvoorbeeld met 9 procentpunt, terwijl een eigen bijdrage die twee keer zo hoog is de kans om scholing te krijgen aangeboden niet significant verder vergroot. Een 100 procent terugbetalingsverplichting blijkt de kans om scholing aangeboden te krijgen wél significant te vergroten ten opzichte van een 50 procent terugbetalingsverplichting. Maar ook dit betekent niet dat de kans op een scholingsinvestering verdubbelt als de terugbetalingsverplichting verdubbelt: een 50 procent terugbetalingsverplichting vergroot de kans op scholing met 16 procentpunt, terwijl een 100 procent terugbetalingsverplichting de kans op scholing met 26 procentpunt verhoogt. 


\section{Afruil tussen werknemerskenmerken}

In deze paragraaf staan twee vragen centraal. Allereerst kijken we naar de vraag in hoeverre werknemers met tijdelijke contracten hun lagere kans om scholing aangeboden te krijgen kunnen compenseren door een eigen financiële bijdrage. ${ }^{63}$ Daarnaast kijken we naar de vraag in hoeverre werkgevers in hogere mate bereid zijn om in de scholing van werknemers met een tijdelijke aanstelling te investeren als er een terugbetalingsovereenkomst kan worden afgesloten.

Tijdelijke werknemers zónder uitzicht op vast werk hebben zelfs bij een relatief hoge eigen financiële bijdrage een veel lagere scholingskans dan tijdelijke werknemers mét uitzicht op vast of vaste medewerkers.
Figuur 5.10 laat zien in hoeverre een eigen financiële bijdrage de kans om scholing aangeboden te krijgen beïnvloed voor de verschillende contracttypen. ${ }^{64}$ Op de horizontale as zijn de verschillende contracttypen uit het vignetexperiment gegeven en

op de verticale as de kans dat een werknemer een cursus aangeboden krijgt. De drie doorgetrokken lijnen representeren ieder één bepaalde terugbetalingsregeling. De figuur maakt duidelijk dat voor elk contracttype de kans om scholing aangeboden te krijgen groter is als de werknemer bereid is om een eigen financiële bijdrage te leveren. Hierbij dient wel te worden opgemerkt dat de bereidheid om een eigen bijdrage van 400 euro te leveren geen statistisch significant hogere kans op scholing biedt dan de bereidheid om een eigen bijdrage van 200 euro te leveren. Voor werknemers met een tijdelijke aanstelling mét uitzicht op vast geldt dat zij bij een eigen bijdrage van 200 euro een vergelijkbare kans op scholing hebben als werkenden met een vaste aanstelling die geen eigen bijdrage leveren (de verschillen ten opzichte van laatstgenoemde groep zijn niet statistisch significant). De verschillen ten opzichte van werknemers met een vast contract die wél bereid zijn een eigen bijdrage van 200 euro te leveren zijn wel significant. ${ }^{65}$ Werknemers met een tijdelijk contract mét uitzicht op vast zijn dus in staat om hun lagere kans op scholing deels te compenseren door een het leveren van een eigen financiële bijdrage. Voor werkenden met een tijdelijke aanstelling zonder uitzicht op een vaste aanstelling zijn de vooruitzichten minder rooskleurig: zelfs als deze groep werkenden bereid is een eigen bijdrage van maar liefst 400 euro te leveren komen zij qua kans op scholing nog niet in de buurt van hun collega's met een tijdelijk contract mét uitzicht op vast die geen eigen bijdrage leveren, laat staan dat zij qua scholingskans in de buurt komen van werkenden met een vaste aanstelling.

63 Eerder onderzoek laat bijvoorbeeld zien dat flexwerkers minder vaak een door de werkgever bekostigde cursus volgen en dit deels, maar niet volledig, compenseren door zelf meer te investeren in hun eigen scholing (Fouarge et al, 2011).

64 De scholingskansen in deze figuur hebben betrekking op een cursus die inzetbaar is binnen zowel de huidige organisatie als organisaties binnen dezelfde bedrijfstak en waarvoor de medewerker bij vroegtijdig vertrek binnen 1 jaar $50 \%$ van de cursuskosten terugbetaalt.

65 Hetzelfde geldt uiteraard ten opzichte van werkenden met een vast contract die bereid zijn een eigen bijdrage van 400 euro te leveren. 
FIGUUR 5.10 Kans dat werknemer scholing aangeboden krijgt afhankelijk van de eigen financiële bijdrage aan de scholing

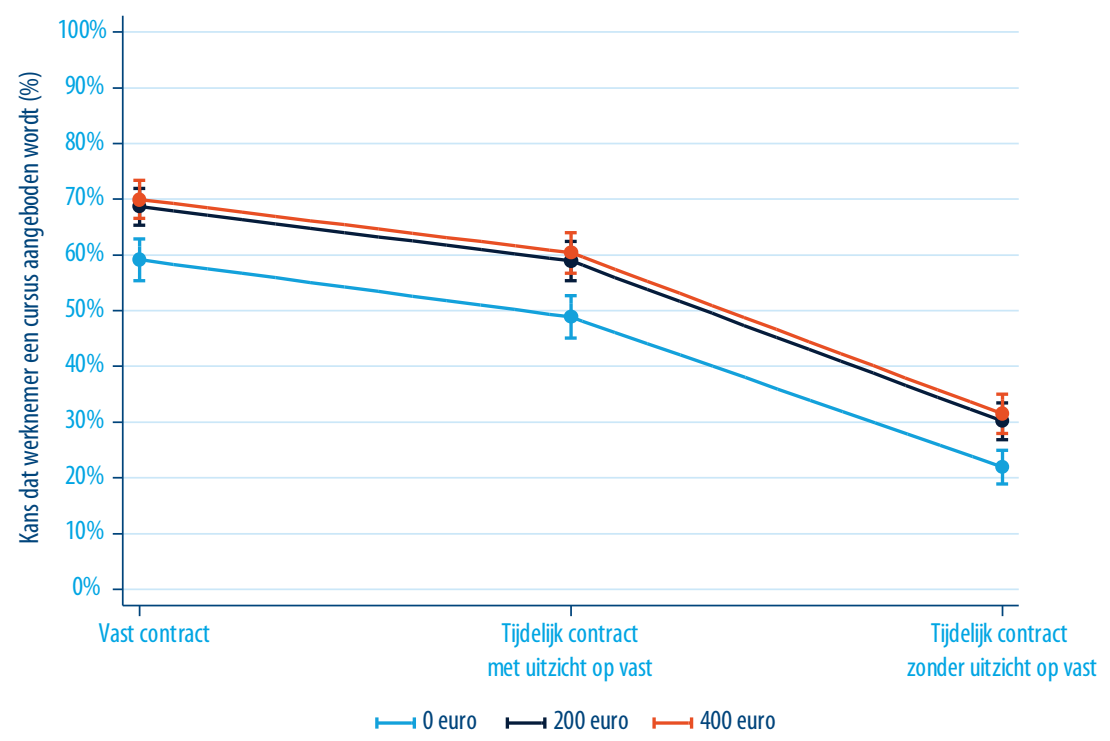

Bron: ROA Werkgeversenquête Scholingsbeleid, 2017

Noot: gebaseerd op probit regressie met cluster-robuuste standaardfouten.

In Figuur 5.11 wordt de afruil tussen het contracttype en verschillende terugbetalingsregelingen voor de kans om scholing aangeboden te krijgen in beeld gebracht. ${ }^{66} \mathrm{De}$ figuur is qua opzet vergelijkbaar met Figuur 5.10. Uit de figuur is een aantal zaken af te leiden. Ten eerste blijkt dat een striktere terugbetalingsverplichting, uitgedrukt in het percentage van de totale trainingskosten dat moet worden terugbetaald bij vroegtijdig vrijwillig vertrek binnen 1 jaar, de kans om scholing aangeboden te krijgen voor alle contracttypen vergroot. In tegenstelling tot de eigen financiële bijdragen is hier nauwelijks sprake van een afnemend effect als de terugbetalingsverplichting toeneemt van 50 procent tot 100 procent van de trainingskosten.

66 De scholingskansen in deze figuur hebben betrekking op een cursus die inzetbaar is binnen de huidige organisatie en organisaties binnen dezelfde bedrijfstak en waarvoor de medewerker een eigen bijdrage van 200 euro levert. 
Als werknemers met een tijdelijk contract mét perspectief op vast gebonden zijn aan een terugbetalingsverplichting van $50 \%$ van de scholingskosten bij vroegtijdig vertrek hebben zijn een vergelijkbare scholingskans als vaste medewerkers zónder enige terugbetalingsverplichting.

Een ander belangrijk verschil in vergelijking met de eigen financiële bijdrage is dat zowel werkenden met een tijdelijke aanstelling zónder uitzicht op vast als werkenden met een tijdelijke aanstelling mét uitzicht op vast door een terugbetalingsregeling compensatiemogelijkheden hebben waarmee de kans om scholing aangeboden te krijgen in de buurt komt van die van werkenden met een vast arbeidscontract. Werkenden met tijdelijke contracten mét uitzicht op vast hebben onder een terugbetalingsverplichting van 50 procent zelfs een grotere kans om scholing aangeboden te krijgen dan werkenden met een vast contract zonder terugbetalingsverplichting. Het lukt werkenden met een tijdelijk contract met uitzicht op vast werk echter niet om boven de scholingskans van werkenden met een vast contract met een terugbetalingsverplichting van 50 procent uit te komen, ook niet als de tijdelijke werknemers met uitzicht op vast werk zich verplichten om de volledige trainingskosten terug te betalen als zij het bedrijf vroegtijdig verlaten.

Voor werknemers met een tijdelijk contract zonder uitzicht op vast werk is bij een terugbetalingsverplichting van 50 procent de kans op scholing nog steeds fors lager dan onder vaste medewerkers en tijdelijke werknemers die wél uitzicht op een vaste aanstelling hebben. Dit is zelfs het geval als laatstgenoemde groepen bij vroegtijdig vertrek geen scholingskosten hoeven terug te betalen. Alleen werkenden met een tijdelijke aanstelling zonder perspectief op vast werk die de volledige scholingskosten moeten terugbetalen bij vroegtijdig vertrek, hebben een vergelijkbare scholingskans als werkenden met een tijdelijk contract met uitzicht op een vaste aanstelling. Met werkenden met een vast contract kunnen zij niet concurreren, ook niet als de werkenden met een tijdelijk contract zonder uitzicht op vast werk de volledige scholingskosten bij vroegtijdig vertrek moeten terugbetalen en werkenden met een vast contract geen enkele terugbetalingsverplichting hebben.

Tijdelijke werknemers zónder uitzicht op vast hebben altijd een lagere kans op scholing dan vaste medewerkers. Ook als de tijdelijke werknemer $100 \%$ van de scholingskosten moet terugbetalen bij vroegtijdig vertrek en de vaste werknemer niets hoeven terug te betalen.

lingskansen aanzienlijk vergroten 24 procentpunt (van 17\% naar 41\%). Dit illustreert dat werkgevers niet alleen minder investeren in de scholing van tijdelijke werknemers die zij geen vast werk willen aanbieden, maar ook dat werkgevers terughoudender zijn omdat ze bang zijn dat deze medewerkers al voor het aflopen van hun contract vertrekken.

Al met al zijn de compensatiemogelijkheden van een terugbetalingsverplichting voor werknemers met tijdelijke contracten, vooral bij degenen zonder uitzicht op vast werk, beperkt. Desalniettemin kunnen werknemers met een tijdelijke contracten zonder uitzicht op vast werk door een terugbetalingsverplichting van 100 procent hun scho- 
FIGUUR 5.11 Kans dat werknemer scholing aangeboden krijgt afhankelijk van verschillende typen terugbetalingsregelingen bij vroegtijdig vertrek

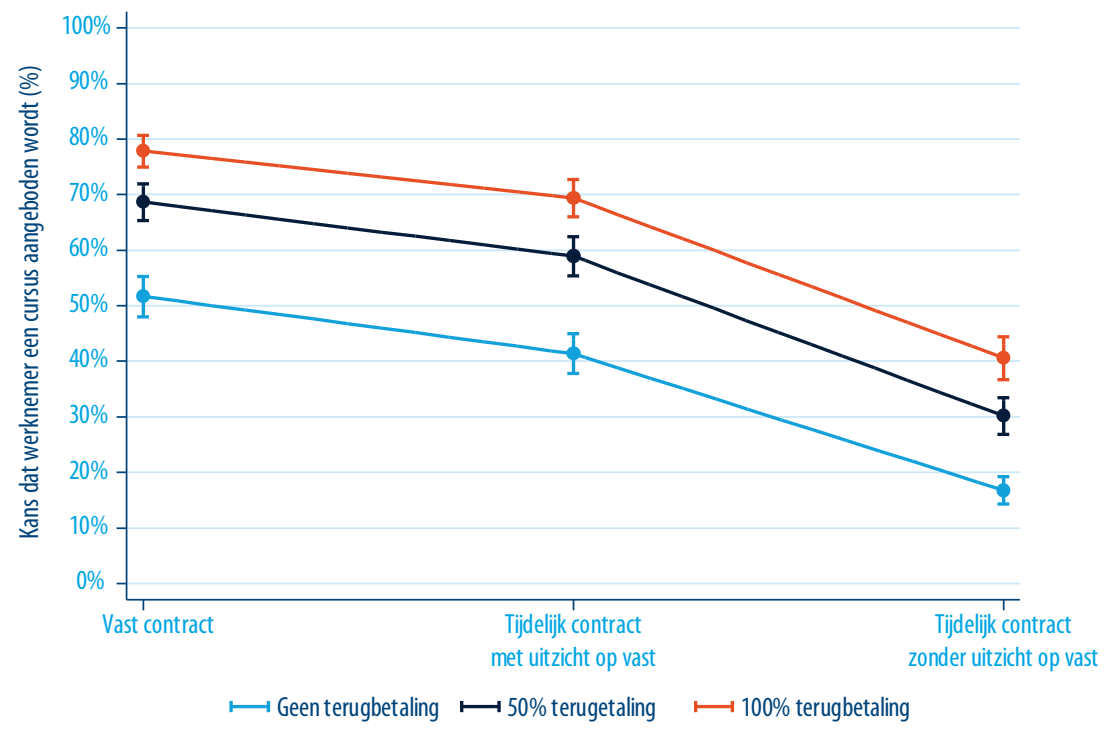

Bron: ROA Werkgeversenquête Scholingsbeleid, 2017

Noot: gebaseerd op probit regressie met cluster-robuuste standaardfouten. 



\section{LITERATUUR}

Akgündüz, Y.E. \& Huizen, T.M. van (2015). Training in two-tier labor markets: the role of job match quality. Social Science Research, 52, 508-521.

Arrow, K. (1962). The economic implications of learning by doing. Review of Economic Studies, 29, pp. 166-170.

Armstrong-Stassen, M., \& Ursel, N.D. (2009). Perceived organizational support, career satisfaction, and the retention of older workers. Journal of Occupational and Organizational Psychology, 82, 201-220.

Bates (2001). Public sector training participation: an empirical investigation, International Journal of Training and Development, 5(2), 136-152

Becker, G. (1964). Human Capital: A Theoretical and Empirical Analysis with special reference to education ( $3^{\text {rd }}$ ed.). Chicago: The University of Chicago Press.

Bierings, H., \& Loog, B. (2013). Verwachte baanvindduren werkloze 45-plussers, Sociaaleconomische trends, 2013-2

Bijlsma, I., Dijksman, S., Fouarge, D., \& Künn-Nelen, A. (2015). Winnaars en verliezers op de arbeidsmarkt 1996-2012. Tijdschrift voor Arbeidsvraagstukken, 31(2), 106-123.

Blau, P. (1964). Exchange and Power in Social Life. New York, Wiley.

Bolhaar, J., Brouwers, A., \& Scheer, B. (2016). De flexibele schil van de Nederlandse arbeidsmarkt: een analyse op basis van microdata. CPB achtergronddocument, 17 november 2016

Borghans, L, Fouarge, D., Grip, A. de, \& Thor, J. van. (2014). Werken en leren in Nederland, ROA-R$2014 / 3$

Borghans, L., Ter Weel, B., \& Weinberg, B. A. (2008). Interpersonal styles and labor market outcomes. Journal of Human Resources, 43(4), 815-858).

Caroli, E., \& Reenen, J. van. (2001). Skill-biased organizational change? Evidence from a panel of British and French establishments. Quarterly Journal of Economics, 116(4), 1449-1492.

Cockx, B., \& Picchio, M. (2012). Are short-lived jobs stepping stones to long-lasting jobs? Oxford Bulletin of Economics and Statistics, 74(5), 646-675.

Cunha, F., \& Heckman, J. (2007). The Technology of Skill Formation. The American Economic Review, 97(2), 31-47.

Dekker, R. \& Mooi-Reci, I. (2011). Tijdelijk werk: Zegen of vloek? In R. Gaalen, van, J. Sanders, W. Smits, \& J.F. Ybema (red.). Dynamiek op de Nederlandse arbeidsmarkt, 98-114. Den Haag/Hoofddorp: CBS/TNO.

Euwals, R., Vuuren, D. van, \& Wolthoff, R. (2010). Early retirement behaviour in the Netherlands: Evidence from a policy reform. De Economist, 158(3), 209-236. 
Falk, A., Becker, A., Dohmen, T. J., Huffman, D., \& Sunde, U. (2016). The preference survey module: A validated instrument for measuring risk, time, and social preferences, IZA DP 9674

Ferreira, M., Künn, A., \& Grip, A. de (2017). Work-related learning and skill development in Europe: Does initial skill mismatch matter? Research in Labor Economics, 45, 345-407.

Fouarge, D., van Eldert, P., de Grip, A., Künn-Nelen, A., Poulissen, D. (2018). Nederland in leerstand, ROA-R-2018/\#\#

Fouarge (2017). Veranderingen in werk en vaardigheden. Oratie.

Fouarge, D. \& Grip, A. de. (2013). Complexiteit, specialisatie en effectiviteit van het werk in Nederland. In: B. ter Weel \& S. Kok. De Nederlandse arbeidsmarkt in taken. Eerste bevindingen uit de Nederlandse Skills Survey. CPB: The Hague.

Fouarge, D., Schils, T., \& Grip, A. de. (2013). Why do low-educated invest less in further training? Applied Economics, 45, 2587-2601

Fouarge, D., Grip, A. de, Smits, W. \& de Vries, R. (2012). Flexible contracts and human capital investments. De Economist, 160(2), 177-195.

Germeijs,V. \& De Boeck, P. (2002). A Measurement Scale for Indecisiveness and its Relationship to Career Indecision and Other Types of Indecision. European Journal of Psychological Assessment, $18(2), 113-122$

Graaf-Zijl, M. de, A. Horst, van der, \& D. Vuuren, van. (2015). Langdurige Werkloosheid: Afwachten én Hervormen, CPB Policy Brief 2015/11.

Graaf-Zijl, M. de, Berg, G.J. van den, \& Heyma, A. (2011). Stepping stones for the unemployed: the effect of temporary jobs on the duration until (regular) work. Journal of Population Economics, 24(1), 107-139.

Heckman, J. J. (2007). The Economics, Technology, and Neuroscience of Human Capability Formation. Proceedings of the National Academy of Sciences of the United States of America, 104(33), 13250-13255.

Humburg, M., \& Velden, R. van der (2015). Skills and the graduate recruitment process: Evidence from two discrete choice experiments. Economics of Education Review, 49, 24-41.

Katz, L. \& Autor, D. (1999). Changes in the wage structure and earnings inequality. In O. Ashenfelter \& D. Card (red.), Handbook of Labor Economics, vol. 3, 1463-1555, Amsterdam: Elsevier.

Leufvén, M., Vitrakoti, R., Bergström, A., Ashish, K. C., \& Målqvist, M. (2015). Dimensions of Learning Organizations Questionnaire (DLOQ) in a low-resource health care setting in Nepal. Health research policy and systems, 13(1), 6.

Montizaan, R., Cörvers, F., \& Grip, A. de. (2010). The effects of pension rights and retirement age on training participation: Evidence from a natural experiment. Labour Economics, 17(1), 240-247.

Montizaan, R., Fouarge, D., \& Grip, A. de. (2016), Ouderen worden ondergewaardeerd door werkgevers, Tijdschrift over ouder worden \& samenleving, 36-39, 2016/2.

Nelen, A., \& Grip, A. de (2009), Why Do Part-time Workers Invest Less in Human Capital than Fulltimers?. Labour, 23(s1), 61-83.

Nelen, A. (2012), Part-Time Employment and Human Capital Development, Maastricht: Research Centre for Education and the Labour Market (ROA)

Offerhaus, J. (2013). The Type to Train? Impacts of Personality Characteristics on Further Training Participation, SOEPpaper No. 531

ROA (2017), Werkenden in leerstand, ROA-F-2017/4 
Schaufeli, W. B., \& Bakker, A. B. (2004). Bevlogenheid: Een begrip gemeten. Gedrag en Organisatie, 17, 89-112.

Taylor, J., \& Deane, F. P. (2002). Development of a Short Form of the Test Anxiety Inventory (TAI). The Journal of General Psychology, 129(3), 127-136

Dalen, H. P. van, \& Schippers, J. (2010). Productivity of older workers: Perceptions of Employers and Employees. Population and Development Review, 36(2), 309-330.

Ours, J.C. van, \& Stoeldraijer, L. (2011). Age, Wage and Productivity in Dutch Manufacturing, De Economist, vol. 159(2), 113-137

Wijk, E. van, Klein Hesselink, J., Verbiest, S., Kooij-de Bode, H. \& Goudswaard, A. (2013). Flexibiliteit en ontwikkelmogelijkheden: perspectief van de werknemer. In R. Gaalen, van, A. Goudswaard, J. Sanders \& W. Smits (red.). Dynamiek op de Nederlandse arbeidsmarkt (pp. 47-58). Den Haag/ Hoofddorp: CBS/TNO. 



\section{BIJLAGE A}

\section{TABEL A.1 Samenstelling van de steekproef}

\begin{tabular}{|c|c|}
\hline & 2017 \\
\hline Totaal & 4791 \\
\hline \multicolumn{2}{|l|}{ Geslacht } \\
\hline $\operatorname{man}$ & 2215 \\
\hline vrouw & 2576 \\
\hline \multicolumn{2}{|l|}{ Leeftijd } \\
\hline $16-24$ & 487 \\
\hline $25-34$ & 591 \\
\hline $35-44$ & 709 \\
\hline $45-54$ & 918 \\
\hline $55-66$ & 1251 \\
\hline $67+$ & 835 \\
\hline \multicolumn{2}{|l|}{ Opleidingsniveau ${ }^{67}$} \\
\hline basisonderwijs & 364 \\
\hline vmbo & 957 \\
\hline havo/vwo & 540 \\
\hline mbo & 1188 \\
\hline hbo & 1188 \\
\hline wo & 546 \\
\hline \multicolumn{2}{|l|}{ Arbeidsmarktstatus } \\
\hline verricht betaald werk in loondienst & 2281 \\
\hline werkt of is meewerkend in gezins- of familiebedrijf & 49 \\
\hline is vrije beroepsbeoefenaar, freelance of zelfstandige & 232 \\
\hline zoekt werk na verlies werkkring & 128 \\
\hline zoekt voor het eerst werk & 14 \\
\hline gaat naar school of studeert & 429 \\
\hline verzorgt de huishouding & 326 \\
\hline is met pensioen (vervroegd, aow of vut) & 925 \\
\hline is (gedeeltelijk) arbeidsongeschikt & 208 \\
\hline verricht onbetaald werk met behoud van uitkering & 20 \\
\hline verricht vrijwilligerswerk & 130 \\
\hline doet iets anders & 42 \\
\hline is te jong, heeft nog geen bezigheden & 7 \\
\hline
\end{tabular}

67 In het rapport wordt ook wel verwezen naar laagopgeleiden (basisonderwijs of vmbo), middelbaar opgeleiden (mbo of havo/vwo) en hoogopgeleiden (hbo of wo). 
TABEL A.2 Meting van het werkgerelateerd leren in de ROA Levenslang Leren Enquête

\begin{tabular}{|l|l}
\hline Variabele & Vraag \\
\hline Deelname aan cursussen en trainingen & $\begin{array}{l}\text { Hoeveel cursussen en/of trainingen hebt u in de afgelopen twee jaar } \\
\text { afgerond? Laat pure hobby-cursussen (bridge, schilderen) buiten } \\
\text { beschouwing. Cursussen die u als hobby ziet, maar voor anderen } \\
\text { nuttig kunnen zijn voor het werk tellen wel mee. }\end{array}$ \\
\hline Informeel leren op het werk & $\begin{array}{l}\text { Hoeveel procent van de werktijd besteedt u aan taken waarvan u } \\
\text { kunt leren? }\end{array}$
\end{tabular}


TABEL A.3 Variabelen behorende bij de onderscheiden clusters determinanten, incl. bron

\begin{tabular}{|c|c|c|}
\hline Naam groep determinanten & Onderliggende variabelen & Bron \\
\hline Standaard controlevariabelen & $\begin{array}{l}\text { Geslacht } \\
\text { Omvang contract (in uren) } \\
\text { Duur contract (in jaren) } \\
\text { Leeftijd' } \\
\text { Opleidingsniveau' } \\
\text { Type contract (vast, tijdelijk met uitzicht op vast, tijdelijk zonder } \\
\text { uitzicht op vast, zelfstandige) }\end{array}$ & $\begin{array}{l}\text { ROA LLL } 2017 \\
\text { ROA LLL } 2017 \\
\text { ROA LLL } 2017 \\
\text { ROA LLL } 2017 \\
\text { ROA LLL } 2017 \\
\text { ROA LLL } 2017\end{array}$ \\
\hline Persoonlijkheid & $\begin{array}{l}\text { Examenvrees (TAl short, Taylor \& Deane 2002) } \\
\text { Besluiteloosheid (Germeijs \& De Boeck 2002) } \\
\text { Bevlogenheid (Schaufeli et al., 2004) } \\
\text { Positieve reciprociteit (Falk et al., 2016) } \\
\text { Tijdsvoorkeur (Falk et al., 2016) } \\
\text { Risicovoorkeur (Falk et al., 2016) } \\
\text { Openstaan voor nieuwe ervaringen (big5) } \\
\text { Zorgvuldigheid (big5) } \\
\text { Extraversie (big5) } \\
\text { Servicegerichtheid (big5) } \\
\text { Emotionele stabiliteit (big5) } \\
\text { Vertrouwen (Falk et al., 2016) } \\
\text { Leermotivatie ( Theranou, 2001) }\end{array}$ & $\begin{array}{l}\text { ROA LLL } 2017 \\
\text { ROA LLL } 2017 \\
\text { ROA LLL } 2017 \\
\text { ROA LLL } 2017 \\
\text { ROA LLL 2017 } \\
\text { ROA LLL 2017 } \\
\text { LISS 2016 } \\
\text { LISS 2014/6/7 } \\
\text { LISS 2014/6/7 } \\
\text { LISS 2014/6/7 } \\
\text { LISS 2014/6/7 } \\
\text { LISS 2014/6/7 } \\
\text { LISS 2017 } \\
\text { ROA LLL 2017 }\end{array}$ \\
\hline Leefstijl & $\begin{array}{l}\text { Roken ja/nee } \\
\text { Frequentie alcoholconsumptie } \\
\text { BMI }\end{array}$ & $\begin{array}{l}\text { LISS } 2016 \\
\text { LISS } 2016 \\
\text { LISS } 2016\end{array}$ \\
\hline Leefsituatie & $\begin{array}{l}\text { Woonvorm (alleenstaand, samenwonend zonder kinderen, } \\
\text { samenwonend met kinderen, alleenstaand met kinderen, anders) } \\
\text { Aantal thuiswonende kinderen }\end{array}$ & $\begin{array}{l}\text { ROA LLL } 2017 \\
\text { ROA LLL } 2017 \\
\text { ROA LLL } 2017 \\
\text { ROA LLL } 2017 \\
\text { ROA LLL } 2017\end{array}$ \\
\hline$H R$ & $\begin{array}{l}\text { Leerklimaat (Leufvén et al., 2015) } \\
\text { HR-instrumenten: } \\
\text { - Functionerings- en/of beoordelingsgesprekken } \\
\text { - Persoonlijk opleidings- of ontwikkelplan } \\
\text { - Regelmatige feedback van uw leidinggevende } \\
\text { - Regelmatige feedback door collega's } \\
\text { - Loopbaanplan } \\
\text { - Coaching } \\
\text { - Functieroulatie } \\
\text { - Taakroulatie } \\
\text { - Detachering bij andere afdelingen binnen dezelfde organisatie } \\
\text { - Prestatiebeloning of bonussen }\end{array}$ & $\begin{array}{l}\text { ROA LLL } 2017 \\
\text { ROA LLL } 2017\end{array}$ \\
\hline Inhoud werk & $\begin{array}{l}\text { Organisatorische veranderingen (1-5) } \\
\text { Technologische veranderingen (1-5) } \\
\text { Concurrentie in de markt (1-5) } \\
\text { Stabiliteit vraag in de markt (1-5) }\end{array}$ & $\begin{array}{l}\text { ROA LLL } 2017 \\
\text { ROA LLL } 2017 \\
\text { ROA LLL } 2017 \\
\text { ROA LLL } 2017\end{array}$ \\
\hline
\end{tabular}

Noot: ' Deze variabele wordt niet meegenomen als de focus van de analyse ligt op het in kaart brengen van de determinanten van deze specifieke groep werkenden. 
TABEL A.4 Taken NSS per geaggregeerde groep ${ }^{68}$

\begin{tabular}{|c|c|}
\hline Groep & Taak \\
\hline Interpersoonlijke vaardigheden & $\begin{array}{l}\text { omgaan met mensen } \\
\text { samen werken in een team met anderen } \\
\text { goed luisteren naar collega's } \\
\text { het geven van feedback aan collega's }\left(^{*}\right) \\
\text { het instrueren, trainen of iets leren aan anderen } \\
\text { het houden van presentaties } \\
\text { het verkopen van een product of dienst } \\
\text { het overtuigen en beïnvloeden van anderen } \\
\text { het adviseren en begeleiden van klanten of cliënten }\end{array}$ \\
\hline Rekenvaardigheden & $\begin{array}{l}\text { optellen, aftrekken, vermenigvuldigen en delen van getallen } \\
\text { het maken van berekeningen met decimalen, percentages of fracties } \\
\text { gebruik van wiskunde of statistiek om berekeningen te maken }\end{array}$ \\
\hline Taal vaardigheden & $\begin{array}{l}\text { het lezen en beoordelen van formulieren } \\
\text { het lezen en beoordelen van korte rapporten, brieven of memo's } \\
\text { het lezen en beoordelen van lange rapporten, brieven of memo's } \\
\text { het invullen van formulieren } \\
\text { het schrijven van korte rapporten, brieven of memo's } \\
\text { het schrijven van lange rapporten, brieven of memo's }\end{array}$ \\
\hline Fysieke kracht & $\begin{array}{l}\text { fysieke kracht } \\
\text { uithoudingsvermogen } \\
\text { uw behendigheid om een taak te verrichten }\end{array}$ \\
\hline Probleemoplossend vermogen & $\begin{array}{l}\text { het opmerken van fouten of problemen } \\
\text { het oplossen van problemen } \\
\text { het analyseren van problemen } \\
\text { controleren om te voorkomen dat er fouten worden gemaakt of problemen } \\
\text { ontstaan }\end{array}$ \\
\hline Plannen en organiseren & $\begin{array}{l}\text { het plannen van uw eigen werkzaamheden } \\
\text { het plannen van de werkzaamheden van anderen }\end{array}$ \\
\hline Kennis van de organisatie & $\begin{array}{l}\text { kennis van het bedienen van apparaten en machines } \\
\text { kennis van specifieke producten of diensten } \\
\text { gespecialiseerde kennis of begrip die niemand anders in uw organisatie } \\
\text { heeft } \\
\text { kennis van hoe de organisatie van uw bedrijf in elkaar zit en werkt }\end{array}$ \\
\hline \multirow[t]{4}{*}{ Gebruik van computers } & kennis van specifieke software of programmeertalen $\left(^{*}\right)$ \\
\hline & $\begin{array}{l}\text { het werken met een computer om bijvoorbeeld klantgegevens in te voeren } \\
\text { en rekeningen te printen }\end{array}$ \\
\hline & $\begin{array}{l}\text { het werken met een computer om documenten op te stellen, met } \\
\text { spreadsheets te werken, informatie op het internet te zoeken of e-mails te } \\
\text { versturen }\end{array}$ \\
\hline & $\begin{array}{l}\text { het werken met een computer om producten te ontwerpen, statistische } \\
\text { analyses uit te voeren of gecompliceerde berekeningen uit te voeren }\end{array}$ \\
\hline
\end{tabular}

$\overline{68}$ Wij sluiten bij deze groepering aan bij eerder onderzoek (Borghans et al., 2008). 


\section{BIJLAGE B}

FIGUUR B.1 Stimulerende en belemmerende factoren in de cursuskeuze, naar leeftijdscategorie
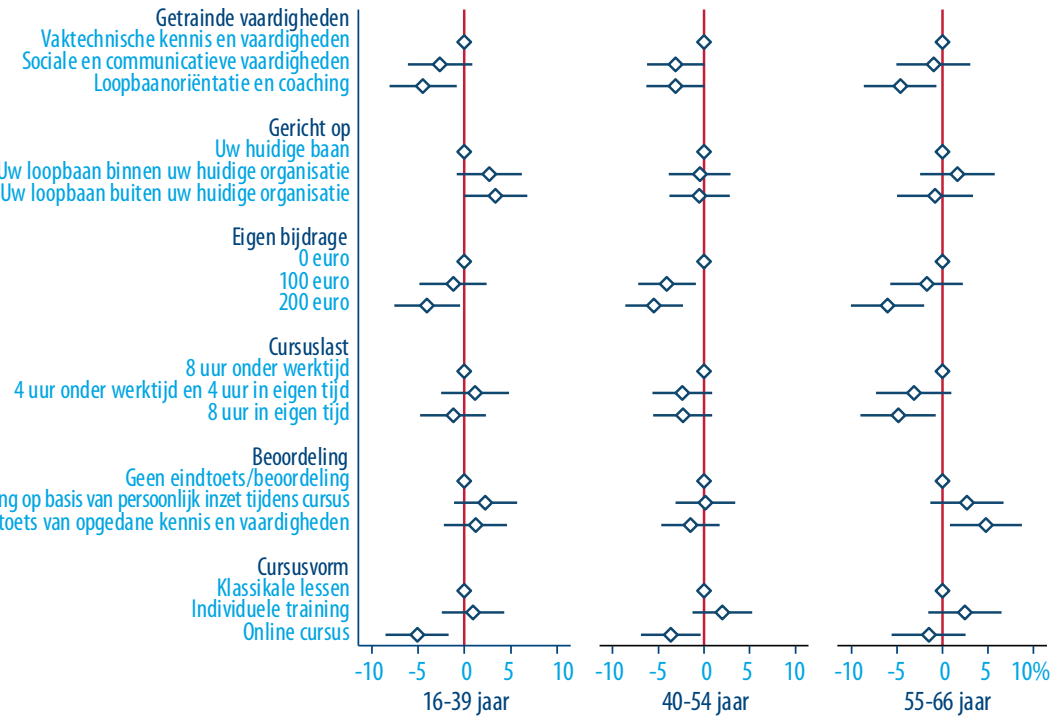

Verandering in kans dat cursus wordt gekozen (gem. marginaal effect), inclusief $95 \%$ betrouwbaarheidsinterval

Bron: ROA LLL Enquête, 2017

Noot: gebaseerd op probit analyses met cluster-robuuste standaardfouten. 
FIGUUR B.2 Stimulerende en belemmerende factoren in de cursuskeuze, naar opleidingscategorie
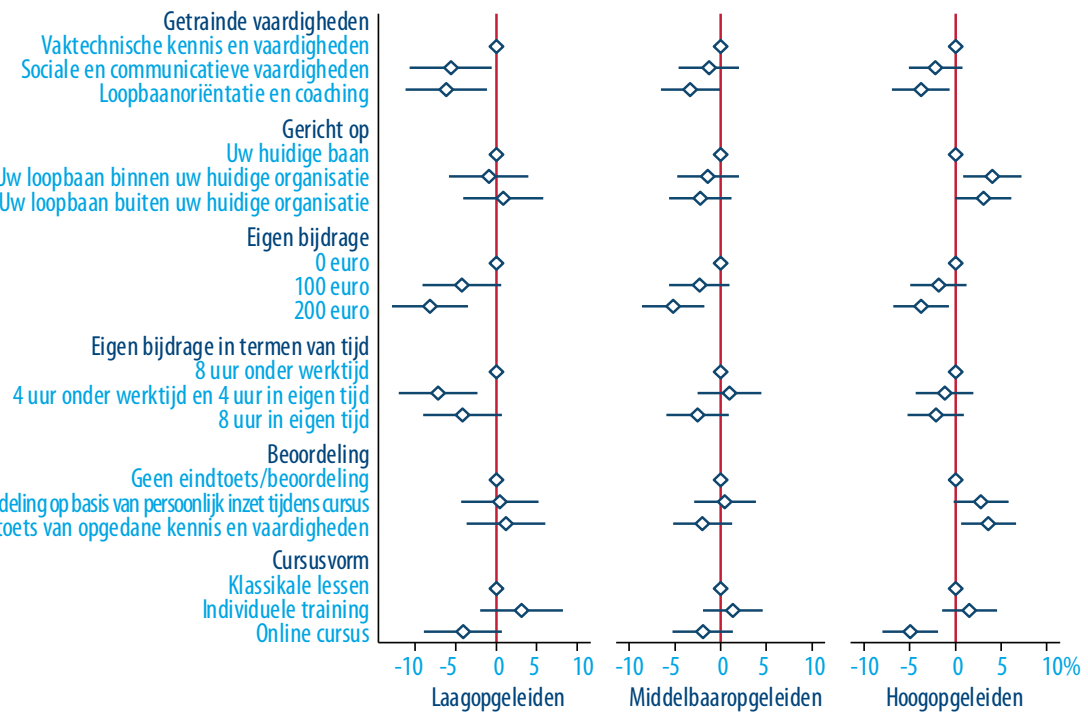

Verandering in kans dat cursus/training wordt gekozen (gemiddeld marginaal effect), inclusief 95\% betrouwbaarheidsinterval

Bron: ROA LLL Enquête, 2017

Noot: gebaseerd op probit analyses met cluster-robuuste standaardfouten. 
FIGUUR B.3 Stimulerende en belemmerende factoren in de cursuskeuze, naar contracttype
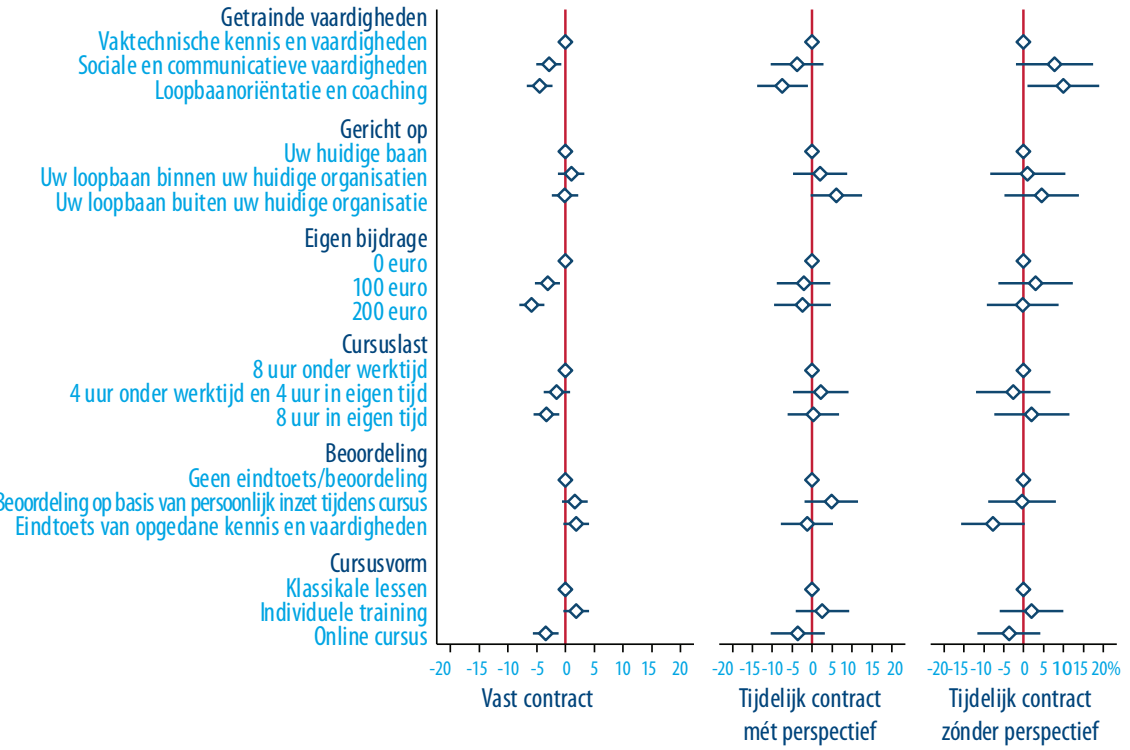

Verandering in kans dat cursus/training wordt gekozen (gemiddeld marginaal effect), inclusief $95 \%$ betrouwbaarheidsinterval

Bron: ROA LLL Enquête, 2017

Noot: gebaseerd op probit analyses met cluster-robuuste standaardfouten. 
